\title{
Simulation of a syngas from coal production plant coupled to a high temperature nuclear reactor
}

\author{
Frederick Johannes Botha
}

Thesis presented in partial fulfilment of the requirements for the degree of Master of Science in Engineering (Mechanical) in the Faculty of Engineering at Stellenbosch University

Supervisor: $\quad$ Mr RT Dobson

Co-supervisor: Prof. TM Harms

December 2012 


\section{DECLARATION}

By submitting this thesis electronically, I declare that the entirety of the work contained therein is my own, original work, that I am the sole author thereof (save to the extent explicitly otherwise stated), that reproduction and publication thereof by Stellenbosch University will not infringe any third party rights and that I have not previously in its entirety or in part submitted it for obtaining any qualification.

Signature:

Date:

Copyright (C) 2012 Stellenbosch University All rights reserved 


\title{
Abstract
}

\section{Simulation of a syngas from coal production plant coupled to a high temperature nuclear reactor}

\author{
F.J. Botha \\ Department of Mechanical and Mechatronic Engineering, \\ University of Stellenbosch, \\ Private Bag X1, Matieland 7602, South Africa. \\ Thesis: MScEng (Mech) \\ December 2012
}

In light of the rapid depletion of the world's oil reserves, concerns about energy security prompted the exploration of alternative sources of liquid fuels for transportation. One such alternative is the production of synthetic fuels with the indirect coal liquefaction process or Coal-To-Liquids (CTL) process. In this process, coal is burned in a gasifier in the presence of steam and oxygen to produce a synthesis gas or syngas, consisting mainly of hydrogen and carbon monoxide. The syngas is then converted to liquid fuels and a variety of useful chemicals in a Fischer Tropsch synthesis reactor. However, the traditional process for syngas production also produces substantial amounts of carbon dioxide. In fact, only about one third of the carbon in the coal feedstock ends up in the liquid fuel product using traditional CTL technology. If additional hydrogen was available, the carbon utilisation of the process could be improved significantly. The high temperature reactor (HTR) is a gas cooled Generation IV nuclear reactor ideally suited to provide electrical power and high temperature heat for the production of carbon neutral hydrogen via high temperature electrolysis. The integration of an HTR into a CTL process therefore provides an opportunity to improve the thermal and carbon efficiency of the CTL process significantly. This thesis presents a possible process flow scheme for a nuclear assisted CTL process. The system is evaluated in terms of its thermal or syngas production efficiency (defined as the ratio of the heating value of the produced syngas to the sum of the heating value of the coal plus the HTR heat input) as well as its carbon utilisation. If the hydrogen production plant is sized to produce only enough associated oxygen to supply in the needs of the gasification plant, syngas is produced at about $63 \%$ thermal efficiency, while $71.5 \%$ of the carbon is utilised in this process. It was found that the optimum HTR outlet temperature to produce hydrogen with a high temperature steam electrolysis process is $850^{\circ} \mathrm{C}$. If enough process heat and electrical power are available and process equipment capacities are sufficient, the carbon utilisation of the process could be improved even further to values in excess of $90 \%$. 


\title{
Uittreksel
}

\section{Simulasie van ' $n$ sintesegas uit steenkool produksie aanleg gekoppel met 'n hoë temperatuur kernreaktor}

\author{
F.J. Botha \\ Departement Meganiese and Megatroniese Ingenieurswese, \\ Universiteit van Stellenbosch, \\ Privaatsak X1, Matieland 7602, Suid Afrika. \\ Tesis: MSclng (Meg) \\ Desember 2012
}

Die uitputting van die wêreld se olie-reserwes, asook kommer oor energiesekuriteit het daartoe gelei dat alternatiewe bronne van vloeibare brandstowwe vir vervoer ondersoek moes word. Een so 'n alternatief is die produksie van sintetiese brandstof d.m.v. die indirekte steenkool vervloeiing proses of sogenaamde Coal-To-Liquids (CTL) proses. In hierdie proses word steenkool in die teenwoordigheid van stoom en suurstof in 'n vergasser gebrand om ' $n$ sintesegas of singas te produseer, wat hoofsaaklik uit waterstof en koolstofmonoksied bestaan. Die sintesegas word daarna omgeskakel na vloeibare brandstowwe en ' $n$ verskeidenheid van nuttige chemikalieë in ' $n$ Fischer-Tropsch-sintese reaktor. Ongelukkig produseer die tradisionele proses vir sintesegas produksie ook 'n beduidende hoeveelheid koolstofdioksied. Trouens, slegs sowat een derde van die koolstof in die steenkool roumateriaal eindig in die vloeibare brandstof produk indien van tradisionele CTL-tegnologie gebruik gemaak word. Indien addisionele waterstof beskikbaar was, kon die koolstofbenutting van die proses aansienlik verbeter word. Die hoë temperatuur reaktor (HTR) is 'n gas-verkoelde Generasie IV kernreaktor wat by uitstek geskik is om elektrisiteit en hoë temperatuur hitte te verskaf vir die produksie van koolstofneutrale waterstof d.m.v. hoë temperatuur elektrolise. Die integrasie van ' $n$ HTR in 'n CTL-proses bied dus ' $n$ geleentheid om die termiese- en koolstofdoeltreffendheid van die CTL-proses aansienlik te verbeter. In hierdie ondersoek word ' $n$ moontlike proses vloeidiagram vir ' $n$ kern-gesteunde CTL-proses voorgestel. Die stelsel is geëvalueer in terme van sy termiese- of sintesegas produksie doeltreffendheid (gedefinieer as die verhouding van die hittewaarde van die geproduseerde sintesegas gedeel deur die som van die hittewaarde van die steenkool en die HTR hitte-insette) sowel as sy koolstof-effektiwiteit. Indien die waterstof produksie-aanleg ontwerp word om net genoeg geassosieerde suurstof te voorsien om in die behoeftes van die vergassing-aanleg te voorsien, word sintesegas teen ongeveer $63 \%$ termiese doeltreffendheid vervaardig, terwyl $71.5 \%$ van die koolstof in hierdie proses benut word. Daar is bevind dat $850{ }^{\circ} \mathrm{C}$ die optimum HTR uitlaat temperatuur is om waterstof d.m.v. hoë temperatuur stoom-elektrolise te vervaardig. Indien daar genoeg proses hitte en elektrisiteit beskikbaar is en die proses toerusting kapasiteite voldoende is, sou die koolstof-benutting van die proses tot meer as $90 \%$ verbeter kon word. 


\section{Acknowledgements}

My Lord and Saviour, Jesus Christ, "in whom are hidden all the treasures of wisdom and knowledge." (Colossians 2:3)

My father, whose vision, encouragement and support enabled the fulfilment of this dream.

My study leaders, Mr Robert Dobson and Prof. Thomas Harms, whose unselfish dedication and valuable guidance were crucial in the success of this project. 


\section{Table of Contents}

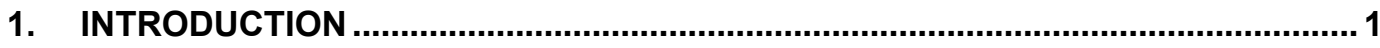

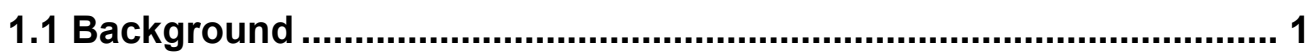

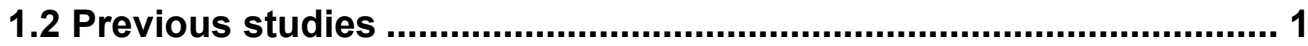

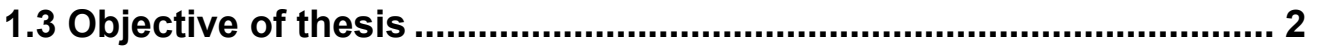

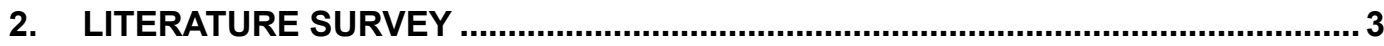

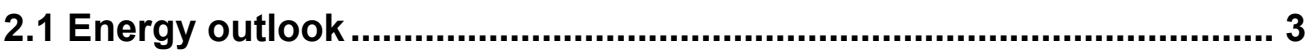

2.1.1 Fossil fuel depletion and climate change .................................. 3

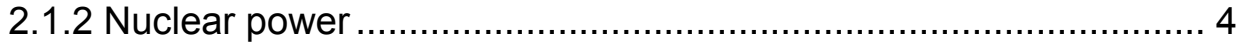

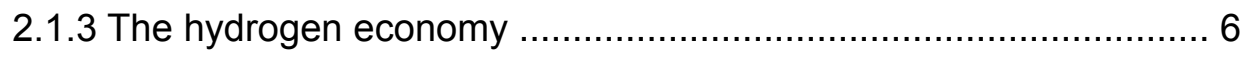

2.2 Water splitting to produce hydrogen ............................................. 7

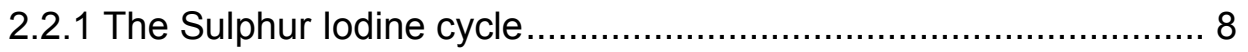



2.2.3 High Temperature Electrolysis.................................................. 9

2.3 Nuclear hydrogen cogeneration system.......................................... 10

2.3.1 High Temperature Gas Cooled Reactor .................................. 10

2.3.2 Intermediate heat exchanger .............................................. 12

2.3.3 Power conversion systems …............................................... 14

2.3.4 Nuclear hydrogen production plant ......................................... 16

2.4 Coal-To-Liquids application ............................................................ 17

2.4.1 The Coal-To-Liquids process ............................................ 18

2.4.2 Coupling of an HTR to a CTL-plant....................................... 20

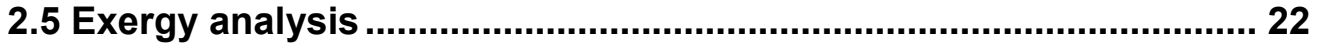

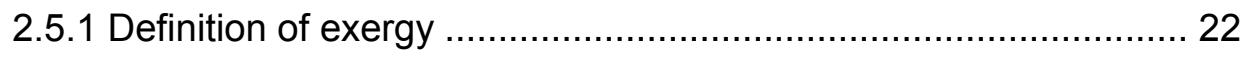

2.5.2 Exergy transfer ......................................................................... 23 


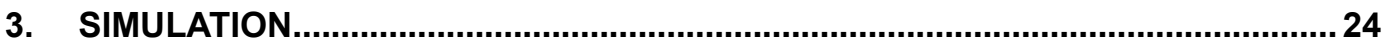

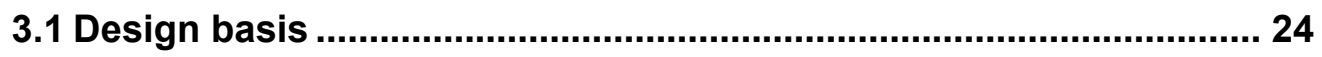

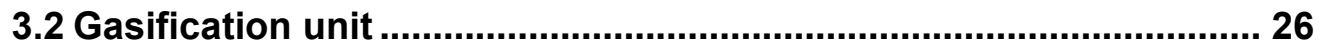

3.2.1 The gasification process ................................................. 26

3.2.2 Types of gasifiers …......................................................... 27

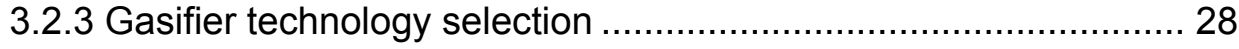

3.2.4 The Shell Coal Gasification Process (SCGP) ........................... 31

3.2.5 Gasifier coal transport gas ................................................. 32

3.2.6 Gasification plant simulation ................................................ 33

3.3 Water Gas Shift Unit........................................................................ 36

3.3.1 The water gas shift reaction ................................................. 36

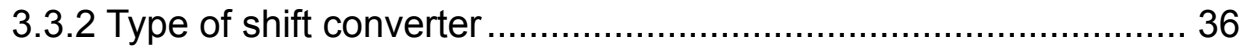

3.3.3 Fundamental WGS reactor model....................................... 37

3.3.4 Validation of WGS reactor model in Aspen Plus ${ }^{\circledR}(2009)$............ 38

3.3.5 Comparison of fundamental WGS reactor model with literature

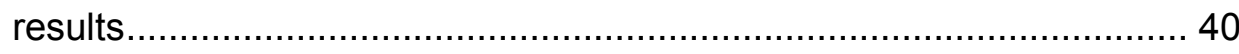

3.4 High Temperature Electrolysis Unit ............................................. 44

3.4.1 Hydrogen production plant technology selection ...................... 44

3.4.2 Thermodynamics of high temperature electrolysis................... 46

3.4.3 Ideal thermal to hydrogen efficiency for water splitting ............... 47

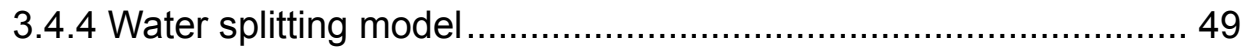

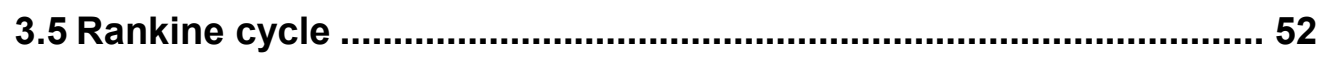

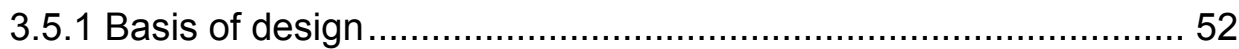

3.5.2 Aspen Plus $₫(2009)$ model of Rankine cycle ............................ 52

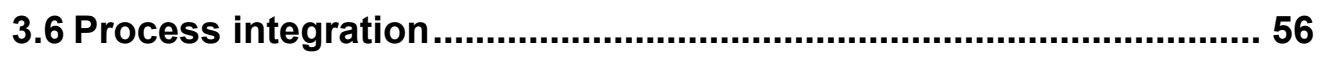

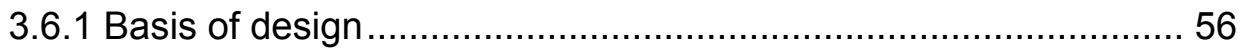


3.6.2 Utilities 56

3.6.3 High Temperature Reactor model ......................................... 57

3.6.4 General considerations for process integration......................... 58



4.1 Process performance of the cogeneration plant ...........................62 62

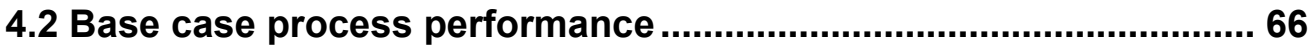

4.3 Optimum reactor outlet temperature ................................................69

4.4 Cogeneration plant reactor outlet temperature dependence study $\mathbf{7 2}$

5. CONCLUSIONS AND RECOMMENDATIONS .78

REFERENCES .81

APPENDIX A:

CALCULATION OF GASIFICATION UNIT SIMULATION PARAMETERS .86

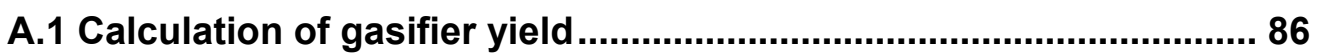

A.2 Calculation of gasifier steam and oxygen requirements ................ 91

A.3 Calculation of gasifier feed streams ................................................. 91

A.4 Calculation of coal transport medium feed stream ........................ 92

APPENDIX B: DERIVATION OF WATER GAS SHIFT REACTOR MODEL 


\section{List of figures}

Figure 1: The world's total primary energy supply by fuel in 2007.

Figure 2: Schematic of the proposed hydrogen future (Adapted from US DoE

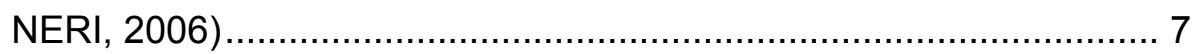

Figure 3: The Sulphur lodine cycle (Elder and Allen, 2009)............................ 8

Figure 4: The Hybrid Sulphur cycle, with typical process conditions for a single module (Adapted from Lahoda et al., 2006) ...................................... 9

Figure 5: The variation in energy requirements to split water at different temperatures (O'Brien, 2008) ..................................................... 10

Figure 6: Intermediate heat exchanger schematics ...................................... 13

Figure 7: Process flow diagram of an ideal reheat-regenerative Rankine cycle (adapted from Çengel and Boles, 2011) ...................................... 15

Figure 8: T-s diagram for an ideal reheat-regenerative Rankine cycle, similar to the process illustrated in Figure 7 (adapted from Çengel and Boles, 2011)

Figure 9: Block flow diagram of a cogeneration plant consisting of four PBMR's coupled to a HyS cycle and one Rankine steam cycle (Lahoda et al., 2006) 18

Figure 10: The indirect coal liquefaction process (Adapted from Perry et al., 2008:24-19). 19

Figure 11: A proposed flow scheme for a PBMR hydrogen production plant coupled to a CTL-plant (Greyvenstein et al., 2008)...

Figure 12: Proposed HTR cogeneration plant coupled to a Coal-To-Liquids (CTL) facility.

Figure 13: Reaction sequence for the gasification of coal (adapted from Higman et al., 2003).

Figure 14: Entrained-flow gasifier efficiency as function of the coal ash content (adapted from Higman et al., 2003:123) 30

Figure 15: Side-fired dry coal feed slagging entrained-flow gasifier (Higman et al., 2003:122) 31

Figure 16: The Shell Coal Gasification Process (Higman et al., 2003:131) ........ 32

Figure 17: Specification of RYield reactor model in Aspen Plus $₫(2009)$........... 34 
Figure 18: Aspen Plus ${ }^{\circledR}$ (2009) simulation of 4000 t/day Shell dry coal feed entrained-flow gasification plant

Figure 19: Clean water gas shift conversion (adapted from IEA GHG Report $\mathrm{PH} 4 / 19,2003)$ 36

Figure 20: Sour water gas shift process (adapted from IEA GHG Report PH4/19, 2003) 37

Figure 21: Illustration of the procedure to determine the equilibrium conversion and temperature for a nonisothermal,adiabatic WGS reactor model 38

Figure 22: Aspen Plus $®$ (2009) model of a WGS reactor 39

Figure 23: Effect of pressure on the heat capacities of species in WGS reaction at a temperature of $300{ }^{\circ} \mathrm{C}$ 41

Figure 24: Aspen Plus $®$ (2009) simulation model of WGS unit. 42

Figure 25: Conceptual design of a HTE cogeneration plant (Adapted from Fujiwara et al., 2008) 44

Figure 26: Thermal to hydrogen efficiencies for electrolysis technologies coupled to advanced nuclear reactors (O'Brien, 2008). 46

Figure 27: Energy balance for the water splitting process 47

Figure 28: Energy requirements for water splitting at 1 bar (NIST data, [S.a]) ... 47

Figure 29: Illustration of a water splitting process with different heat addition temperatures for the power cycle and the electrolyser (O'Brien, 2008)

Figure 30: Maximum possible electrolysis efficiency as function of temperature $\mathrm{T}_{\mathrm{H}, \mathrm{e}}$

Figure 31: Calculated ideal thermal to hydrogen efficiencies for variable and fixed values of $T_{H, P} . T_{L}=20^{\circ} \mathrm{C}$; For fixed case, $T_{H, P}=566{ }^{\circ} \mathrm{C}$. 50

Figure 32: Sample of electrolyser model in Aspen Plus ${ }^{\circledR}$ (2009), showing heat and electricity input with resulting hydrogen production 51

Figure 33: Implementation of electrolyser Aspen Plus ${ }^{\circledR}$ (2009), within the overall plant model. Note that duty and power values in this figure are in MW.

Figure 34: Conceptual design of the HTR-PM steam power conversion cycle

(Zhang et al., 2006) .... 54

Figure 35: Aspen Plus ${ }^{\circledR}$ (2009) model of the steam power conversion (or Rankine) cycle 55 
Figure 36: Aspen Plus ${ }^{\circledR}$ (2009) model of high temperature reactor with helium loop and intermediate heat exchangers.

Figure 37: Process flow diagram of Aspen Plus $®$ (2009) model of integrated cogeneration plant

Figure 38: Calculation of the syngas production efficiency 62

Figure 39: Results of system analysis of nuclear-assisted syngas production from coal by INL (Harvego et al., 2008). 64

Figure 40: Process flow diagram of base case scenario with low temperature electrolysis unit 68

Figure 41: Effect of HTR outlet temperature on exergy efficiency in helium loop 70

Figure 42: The results of a study on the optimum HTR outlet temperatures for various industrial processes (Gandrik et al., 2011).

Figure 43: Modified process flow diagram for the cogeneration plant reactor outlet temperature dependence study with HTR outlet temperature of $880^{\circ} \mathrm{C}$. Note that no helium bypasses the hot intermediate heat exchanger for this study.

Figure 44: Modified process flow diagram for cogeneration plant reactor outlet temperature dependence study, showing the WGS reactor bypass stream. The process conditions shown resulted at an HTR outlet temperature of $880{ }^{\circ} \mathrm{C}$

Figure 45: Economic yield criteria as a function of reactor outlet temperature for the cogeneration plant

Figure 46: Analysis of the variable costs involved in the cogeneration plant reactor outlet temperature dependence study

Figure B-1: Comparison of WGS reactor fundamental model results for different $\mathrm{H}_{2} \mathrm{O} / \mathrm{CO}$ feed ratios 97

Figure B-2: Comparison of WGS reactor fundamental model results for different feed temperatures 97

Figure C-1: Aspen Plus ${ }^{\circledR}$ (2009) model of the steam power conversion cycle. 101

Figure C-2: Exergy losses in Rankine cycle Aspen Plus $₫(2009)$ model. 101 


\section{List of tables}

Table 1: Percentages of nuclear in total domestic electricity generation in 2007

(IEA, 2009:17) …..................................................................... 5

Table 2: HTR plants - development and operation (adapted from Elder and Allen, 2009) 12

Table 3: Intermediate Heat Exchanger parameters for different designs (Adapted from Elder and Allen, 2009).......................................................... 13

Table 4: Overview of nuclear hydrogen programmes (Elder and Allen, 2009) .... 17

Table 5: Chemical reactions in coal gasification (adapted from Perry et al., 2008)

Table 6: Characteristics of different gasifier types (Higman et al., 2003) .... 29

Table 7: Feed composition to WGS reactor model used in the validation of the Aspen Plus $₫(2009)$ model .............................................................. 39

Table 8: Results of Aspen Plus $₫$ (2009) model validation................................. 40

Table 9: Comparison of fundamental WGS model with literature values ............ 41

Table 10: Comparison of hydrogen production thermal to hydrogen efficiencies (adapted from Yildiz and Kazimi, 2006)

Table 11: Final design parameters of the HTR-PM steam power cycle (Zhang et al., 2006 \& 2009). 52

Table 12: Aspen Plus ${ }^{\circledR}$ (2009) model calculation of the thermodynamic efficiency of the Rankine cycle......................................................................... 53

Table 13: Steam utility process conditions ................................................... 56

Table 14: Boiler feed water supply conditions ............................................. 57

Table 15: Results of cogeneration plant Aspen Plus ${ }^{\circledR}$ (2009) model used in calculation of syngas production efficiency and carbon utilisation of process.

Table 16: Electricity users in Aspen Plus $®$ (2009) model of cogeneration plant . 63

Table 17: Sensitivity analysis in feed temperature for RWGS reaction with a feed composition of $55 \% \mathrm{H}_{2}, 15 \% \mathrm{CO}, 21 \% \mathrm{CO}_{2}, 0.2 \% \mathrm{~N}_{2}, 8.8 \% \mathrm{H}_{2} \mathrm{O} \ldots .65$

Table 18: Differences between cogeneration plant and base case simulation.... 66

Table 19: Calculation of the electricity requirement for atmospheric low temperature electrolysis technology (NEL Hydrogen atmospheric electrolyser technical data, [S.a]) 66 
Table 20: Comparison of cogeneration plant process performance with base case scenario 67

Table 21: Sample calculation of exergy destruction in helium loop for an HTR outlet temperature of $850^{\circ} \mathrm{C}$ 69

Table 22: Estimates of the values of cogeneration production variables ............ 76

Table A-1: Analysis of various coals (Higman et al., 2003:46) .......................... 88

Table A-2: Performance of various types of coals in dry coal feed entrained-flow gasifiers (Higman et al., 2003:126) 89

Table A-3: Influence of the coal transport gas on syngas composition (Adapted from Higman et al., 2003:176). 90

Table B-1: Stoichiometric table for flow system (adapted from Fogler, 2006) .... 94

Table B-2: Sample calculation of specific heats of species involved in WGS reaction at $370{ }^{\circ} \mathrm{C}$ 96

Table C-1: Exergy analysis of Rankine cycle (refer to Figure 35 for the flow diagram of the cycle) 100 


\section{List of symbols}

$\begin{array}{lll}\mathrm{C}_{\mathrm{p}} & \text { Specific heat constant } & \mathrm{kJ} / \mathrm{kmol} . \mathrm{K} \\ \mathrm{g} & \text { Gibbs free energy } & \mathrm{kJ} / \mathrm{kg} \\ & \text { or gravitational acceleration } & \mathrm{m} / \mathrm{s}^{2} \\ \mathrm{~h} & \text { Specific enthalpy } & \mathrm{kJ} / \mathrm{kg} \\ \mathrm{H} & \text { Enthalpy } & \mathrm{kJ} \\ \mathrm{HHV} & \text { Higher heating value } & \mathrm{kJ} / \mathrm{mol} \\ \mathrm{K} & \text { Equilibrium constant } & \\ \mathrm{LHV} & \text { Lower heating value } & \mathrm{kJ} / \mathrm{mol} \\ \mathrm{m} & \text { Mass flow rate } & \mathrm{kg} / \mathrm{s} \\ \mathrm{MW} & \text { Electrical power } & \mathrm{MW} \\ \mathrm{MW} & \text { Thermal power } & \mathrm{MW} \\ \mathrm{N} & \text { Mass flow rate } & \mathrm{kg} / \mathrm{h} \\ \mathrm{P} & \text { Pressure } & \mathrm{kPa} \\ \mathrm{Q} & \text { Energy, power } & \mathrm{J} \text { or W } \\ \dot{\mathrm{Q}} & \text { Heat transfer rate } & \mathrm{W} \\ \mathrm{R} & \text { Gas constant } & \mathrm{J} / \mathrm{kg} . \mathrm{K} \\ \mathrm{S} & \text { Specific entropy } & \mathrm{kJ} / \mathrm{kg} \cdot \mathrm{K} \\ \mathrm{S} & \text { Entropy } & \mathrm{kJ} / \mathrm{K} \\ \mathrm{T} & \text { Temperature } & \mathrm{K} \text { or }{ }^{\circ} \mathrm{C} \\ \mathrm{V} & \text { Velocity } & \mathrm{m} / \mathrm{s} \\ \mathrm{W} & \text { Work } & \mathrm{N} / \mathrm{m} \\ \dot{\mathrm{W}} & \text { Work rate } & \mathrm{W} \\ \mathrm{X} & \text { Specific exergy } & \mathrm{kJ} / \mathrm{kg} \\ \mathrm{X} & \text { Exergy or conversion } & \mathrm{J} \\ \mathrm{z} & \text { Exergy flow } & \mathrm{W} \\ & \text { Elevation } & \mathrm{m}\end{array}$

\section{Greek symbols}
$\Delta \quad$ Difference
$\eta \quad$ Efficiency
$\Theta \quad$ Ratio of molar concentration of component to reference component
$\varphi$
Mass flow exergy
$\mathrm{kJ} / \mathrm{kg}$ 


\section{Subscripts}

0

e

EB

eq

$\mathrm{H}$

i

in

L

mass

$\max$

n

net

o

out

$\mathrm{P}$

$\mathrm{R}$

Ref

rev

$\mathrm{Rx}$

$S$

th

tot

Reference conditions at $298.15 \mathrm{~K}$ and $101.325 \mathrm{kPa}$ or environmental temperature

Equilibrium or electrolyser

Energy balance

Equilibrium

High or hydrogen

$i_{\text {th }}$ component

Inlet

Low

Exergy transfer through mass flow

Maximum

Normal conditions at $298.15 \mathrm{~K}$ and $101.325 \mathrm{kPa}$

Netto

Initial condition

Outlet

Primary loop or power cycle

Reaction

Reference conditions

Reversible

Reaction

Secondary loop

Thermal

Total 


\section{Introduction}

\subsection{Background}

The rapid depletion of the earth's fossil fuel supplies, as well as increasing instability in their availability and the requirement to decrease greenhouse gas emissions according to the Kyoto Protocol, makes the development of alternative energy sources of the utmost importance. Renewable energy sources are being developed, but are not yet available on a scale large enough to supply global energy needs. It is therefore accepted that nuclear power will play a significant role in the world's energy supply during this century.

It is also critical to utilise the available energy resources more effectively. One of the best ways of improving the utilisation of energy sources is by using socalled cogeneration techniques, which aim to minimise the loss of low level "waste" heat by utilising this heat more effectively.

The high temperature reactor (HTR) is a gas cooled Generation IV nuclear reactor that uses a graphite-moderated nuclear uranium fuel in the form of a prismatic block or a pebble bed core. This type of reactor can conceptually have an outlet temperature of $1000{ }^{\circ} \mathrm{C}$, which enables high temperature applications such as hydrogen production and power production at high thermal efficiencies. In China, one of the leading HTR development consortiums is currently constructing a demonstration plant, consisting of two 250 MWth pebble-bed modular reactors, known as the HTR-PM project. This project aims to demonstrate the safety and economic competitiveness of HTR technology and is scheduled to start-up during 2015 (Small Nuclear Power Reactors [S.a.]).

\subsection{Previous studies}

In addition to the possibility of cogeneration of electricity and process heat, nuclear energy can also be used for the production of hydrogen through high temperature water splitting processes, as discussed by Miller (2005: 2691) and Fujiwara (2008: 422). Hydrogen is widely recognized as an alternative transportation fuel for $\mathrm{CO}_{2}$ emitting energy sources and has been described as the fuel of the future.

Previously, the Pebble Bed Modular Reactor (Pty) Limited (PBMR), South Africa, announced its shift of focus to use their nuclear reactor technology not only for electricity generation, but also for hydrogen and process heat generation in a so-called cogeneration plant (Kelly, 2009). This strategy will enhance the marketability of HTR technology to energy intensive companies 
which consume massive amounts of hydrogen, electricity and process steam in their chemical process plants and require ways to reduce their carbon footprint. Although some preliminary studies by leading HTR development consortiums suggested possible cogeneration concepts, further research and development is needed to address technological issues before the concept can be commercialised.

\subsection{Objective of thesis}

The objectives of this project are therefore the following:

- Investigate the viability of an HTR assisted coal gasification process. The system will co-produce hydrogen, electricity and synthesis gas (or syngas) using a combination of mature technologies or technologies expected to be commercialised in the next decade.

- Suggest a possible plant flow scheme for an HTR assisted syngas production from coal process and develop a process model for the concept within Aspen Plus ${ }^{\circledR}$ (2009) (a commercial process simulation software package).

- Determine the thermal efficiency and carbon utilisation of the proposed cogeneration plant and compare it to a base case comprising of established technologies.

- Determine the influence of the HTR outlet temperature on process performance and suggest an optimum HTR outlet temperature.

Standard Rankine steam cycle technology is considered in order to convert thermal energy into electricity. 


\section{Literature Survey}

\subsection{Energy outlook}

\subsubsection{Fossil fuel depletion and climate change}

According to an International Energy Agency Report, fossil fuels were responsible for $81.4 \%$ of the world's energy supply (see Figure 1) and $68 \%$ of its electricity generation in 2007 (IEA, 2009). The world's primary energy requirements are predicted to increase by $1.6 \%$ per year (IAEA, 1999) and are expected to double by 2050 due to industrialisation of developing countries and population increase (Elder and Allen, 2009:500). The uneven distribution of the earth's fossil fuel supplies has also given rise to political tension and instability in the world.

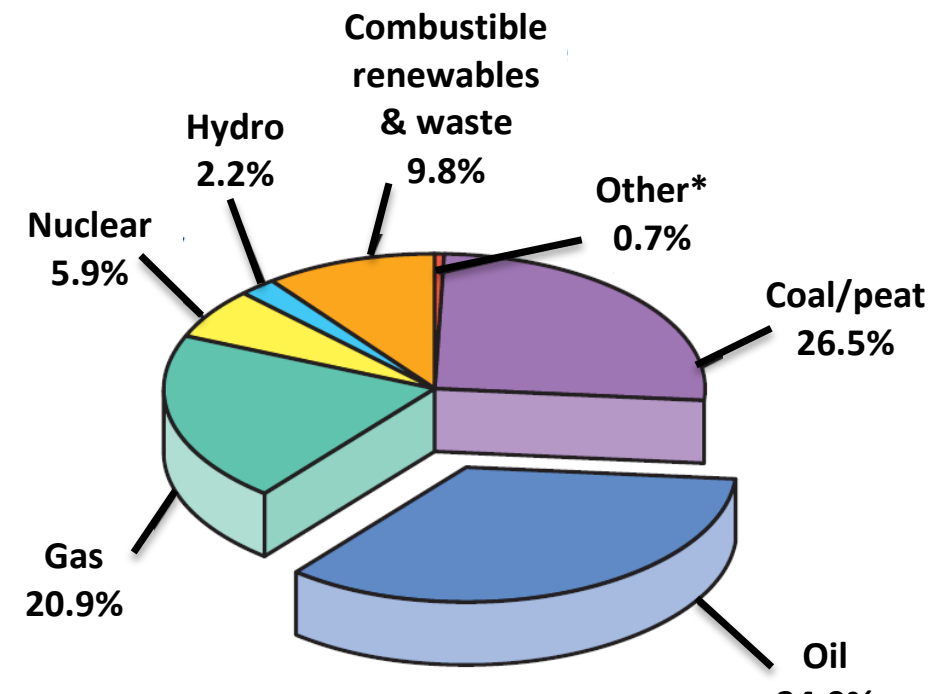

$34.0 \%$

Figure 1: The world's total primary energy supply by fuel in 2007

${ }^{*}$ Other includes geothermal, solar, wind, heat, etc. (IEA, 2009)

Carbon dioxide (or $\mathrm{CO}_{2}$ ), water and methane are primary greenhouse gases, and absorb solar radiation to create a natural insulating blanket around the earth. It is estimated that the earth's temperature would be approximately $30{ }^{\circ} \mathrm{C}$ lower without greenhouse gases, according to Elder and Allen (2009). Once $\mathrm{CO}_{2}$ is released into the atmosphere, it can remain in the atmosphere for centuries. It has been reported that greenhouse gas concentrations in the atmosphere have increased significantly due to human industrial activities. $\mathrm{CO}_{2}$ concentration for example, has increased $35 \%$ from $280 \mathrm{ppm}$ in 1750, to 379 ppm in 2005 (Elder and Allen, 2009:501). The Stern Review warns that, without intervention, $\mathrm{CO}_{2}$ concentrations could reach 550 ppm by 2050 , which will lead to global warming of at least $2{ }^{\circ} \mathrm{C}$ (Stern, 2007). The effects of global warming are far reaching and may include sea level rise, extinction of species, 
glacial retreat and climate change with potentially catastrophic physical and economic consequences.

The broad consensus among scientists concerning global warming, is leading governments to investigate ways to reduce the production of greenhouse gases. Several international summits resulted in the adaptation of the Kyoto Protocol, an amendment to the United Nations Framework Convention on Climate Change (UNFCCC) that aims to fight global warming. This international treaty was initially adopted in 1997 and enforced in February 2005. Signatory countries committed themselves to reduce their greenhouse gas emissions with $5.2 \%$ by 2008 and 2012, compared to 1990 and 1995 levels, respectively.

Considering the fact that fossil fuels are responsible for $75 \%$ of human $\mathrm{CO}_{2}$ production (United Kingdom Department of Environment Food and Rural Affairs, 2008), it is essential that alternative energy sources and energy distribution methods be developed in order to ensure a sustainable future for coming generations.

\subsubsection{Nuclear power}

During 2007, nuclear power accounted for $5.9 \%$ of the world's total primary energy supply and $13.8 \%$ of the world's electricity generation, according to the International Energy Agency Report (IEA, 2009). It is estimated that nuclear power's share in the world's primary energy supply will grow to $9.5 \%$ by 2030, "based on a plausible post 2012 climate policy framework to stabilise the concentration of global greenhouse gases at $450 \mathrm{ppm} \mathrm{CO}_{2}$-equivalent" (IEA, 2009: 46). The percentages of nuclear power in the total domestic electricity generation for the top ten nuclear electricity producers in the world, as well as South Africa, is shown in Table 1.

Considering the fact that nuclear power has vast potential as an energy source, but without any greenhouse gas emissions, it seems that nuclear energy is the ideal solution to supply in the world's energy needs. Unfortunately, nuclear power comes with a few drawbacks, namely production of radioactive waste, the risk of weapons proliferation, as well as potential nuclear incidents such as Chernobyl and Fukushima. For this reason, many groups resist nuclear power as an alternative solution to the global energy crisis.

The use of renewable energy instead of nuclear energy is advocated by many, but the scale of the world's energy needs makes this a noble, but unrealistic ambition, at least in the short to medium term. According to the International Energy Agency Report (IEA, 2009), renewable energy (which includes geothermal, solar, wind heat, etc.), was only responsible for $0.7 \%$ of the 
world's total primary energy supply in 2007 (see Figure 1). Based on the same optimistic policy framework, as mentioned above, this figure will grow with $9 \%$ by 2030 . The huge gap in the world's future energy needs compared to the available clean energy supply, created by fossil fuel depletion and global warming, eliminates the option of ignoring nuclear power as an important future role player in the world's energy supply. The importance of developing new nuclear reactor technologies and increasing public acceptance and awareness towards the nuclear industry, are critical for addressing the problems of global warming and climate change amidst growing world energy demands.

Table 1: Percentages of nuclear in total domestic electricity generation in 2007 (IEA, 2009:17)

\begin{tabular}{|l|c|}
\hline $\begin{array}{l}\text { Country } \\
\text { (top-ten producers) }\end{array}$ & $\begin{array}{l}\text { \% of nuclear in total domestic } \\
\text { electricity generation }\end{array}$ \\
\hline 1.France & 77.9 \\
\hline 2.Ukraine & 47.2 \\
\hline 3.Sweden & 45.0 \\
\hline 4.Korea & 33.6 \\
\hline 5.Japan & 23.5 \\
\hline 6.Germany & 22.3 \\
\hline 7.United States & 19.4 \\
\hline 8.United Kingdom & 16.1 \\
\hline 9.Russian Federation & 15.8 \\
\hline 10.Canada & 14.6 \\
\hline South Africa & 4.6 \\
\hline $\begin{array}{l}\text { Rest of the world } \\
\text { (Excludes countries with no nuclear production) }\end{array}$ & 6.6 \\
\hline World & 13.8 \\
\hline
\end{tabular}

In order to address these challenges, the Generation IV International Forum (GIF) was established to investigate new nuclear energy concepts to meet future energy needs. Generation IV reactors are a new breed of nuclear reactor, specifically designed to address the shortcomings of the previous generation of nuclear reactors. The main goals of the GIF are to develop nuclear reactors that:

- are inherently safe

- address nuclear non-proliferation issues

- have competitive economics

- minimise waste and use natural resources optimally

Generation IV nuclear reactors are currently being developed around the world by a few research and development consortiums and are expected to be commercialised around 2030. 


\subsubsection{The hydrogen economy}

Hydrogen is the third most abundant element on earth, found mostly in organic compounds and water. Although it is high in energy, it combusts without producing any pollution. Hydrogen therefore has the potential to reduce the world's dependence on its depleting fossil fuels reserves, while eliminating greenhouse gas emissions at the same time. However, hydrogen cannot be seen as a primary source of energy, but rather an energy carrier. The hydrogen economy is the ideal of establishing an energy infrastructure that uses hydrogen as an energy carrier (Elder and Allen, 2009:501).

Hydrogen has large potential as a replacement fuel for petroleum by using fuel cell vehicles. A hydrogen fuel cell converts the chemical energy of the hydrogen supplied to it into electrical energy (Larminie and Dicks, 2003). A fuel cell consists of a positively charged cathode and a negatively charged anode divided by an electrolyte. Hydrogen diffuses to the anode and separates into protons (or hydrogen ions) and electrons. The electrons move through the outer circuit and provide electricity, while the protons diffuse through the electrolyte to combine with the electrons and oxygen at the cathode and produce water. Fuel cells can produce electricity at efficiencies of up to $50 \%$. Recently, there has been a shift from using hydrogen in fuel cell vehicles to utilising it to produce synthetic motor fuels by hydrocracking heavy hydrocarbons. Hydrogen is also used to produce synthetic petroleum from coal via the Fischer Tropsch process, most notably at the Sasol Synthetic Fuels plants at Secunda in South Africa. Coal reserves are expected to last longer than oil reserves, which indicates that this route for transportation fuel production will play an important role in the future.

Commercially, hydrogen will be used in fuel cells for electricity production. The fluctuating electricity demand creates a niche market for hydrogen, since it can be used to supply electricity in times of high demand via fuel cells. A nuclear hydrogen production and storage system has been proposed, that will be able to provide fuel for peak electricity production (Forsberg, 2007). The main problem with renewable energy sources is their intermittent nature, which is difficult to match to electricity demand. A hydrogen intermediate and peak electrical system can provide a bridging mechanism that will enable the use of fluctuating renewable energy sources.

Hydrogen can be produced by using fossil fuels or water. Currently, $96 \%$ of hydrogen is produced from fossil fuels; with steam reforming of natural gas contributing $48 \%$ (Elder and Allen, 2009:503). Hydrogen can also be formed by the steam gasification of coal, as well as the thermal cracking of natural gas and the oxidation and cracking of heavy oils. However, all fossil fuels emit significant amounts of $\mathrm{CO}_{2}$, which defeats the purpose, if hydrogen is to be classified as a clean fuel. Hydrogen can also be produced by splitting water, 
using a $\mathrm{CO}_{2}$ free process, but this involves a high temperature step. The most promising of these processes include the Sulphur lodine and the Hybrid Sulphur thermochemical cycles, as well as High Temperature Electrolysis. These processes will be discussed in more detail in the following section. In the short term, hydrogen produced from water splitting will be more expensive than that produced from steam gasification of coal (Engels et al., 1987), although it will probably change in the long term, when carbon emissions are regulated and priced correctly. In assessment of the different routes of hydrogen production, Ewan and Allen (2005) compared various hydrogen production routes on the basis of carbon dioxide emissions, land use implications, primary energy availability and hydrogen production costs. They showed that renewable energy sources have the lowest $\mathrm{CO}_{2}$ production, but the highest land use and are also the most expensive, compared to traditional fossil based and nuclear energy sources. This study concluded that nuclear heat at high temperatures (in the order of $900{ }^{\circ} \mathrm{C}$ ), coupled to thermochemical cycles or steam methane reforming with carbon capture, is the most promising hydrogen production route for the large scale production of hydrogen. A picture of the nuclear hydrogen future can be seen in Figure 2:



Figure 2: Schematic of the proposed hydrogen future (Adapted from US DoE NERI, 2006)

\subsection{Water splitting to produce hydrogen}

Water is a better source of hydrogen than fossil fuels, because no $\mathrm{CO}_{2}$ is emitted in the process. The most viable options to split water are with thermochemical cycles, of which the Hybrid Sulphur and the Sulphur lodine cycles are considered to be the closest to commercialisation (Elder and Allen, 2009:504). High temperature electrolysis is another option for water splitting. 
All these processes require a high temperature step, which can be provided by a solar or nuclear reactor.

\subsubsection{The Sulphur lodine cycle}

The Sulphur lodine (SI) cycle consists of three steps, as shown in Figure 3. Note that the second step occurs at $800{ }^{\circ} \mathrm{C}$ and requires the addition of heat. Laboratory scale experiments in Japan demonstrated stable hydrogen production (Kubo et al., 2004). This cycle produces hydrogen at a predicted thermodynamic efficiency of 35 to $45 \%$.

\subsubsection{The Hybrid Sulphur cycle}

The Hybrid Sulphur (HyS) cycle, is the preferred technology choice for large scale hydrogen production of PBMR (Pty) Ltd (Greyvenstein at al., 2008). A block diagram of the HyS cycle is shown in Figure 4. In the first step, water and sulphur dioxide is electrolysed at around $87^{\circ} \mathrm{C}$ to produce hydrogen and sulphuric acid. The second step is the decomposition of sulphuric acid into sulphur dioxide, steam and oxygen at around $800^{\circ} \mathrm{C}$. Optimisation studies suggest a thermodynamic efficiency for the HyS cycle of $47 \%$ (using a lower heating value) is possible using a temperature of $930{ }^{\circ} \mathrm{C}$ and 10 bar pressure in the decomposition step (Jeong et al., 2005).

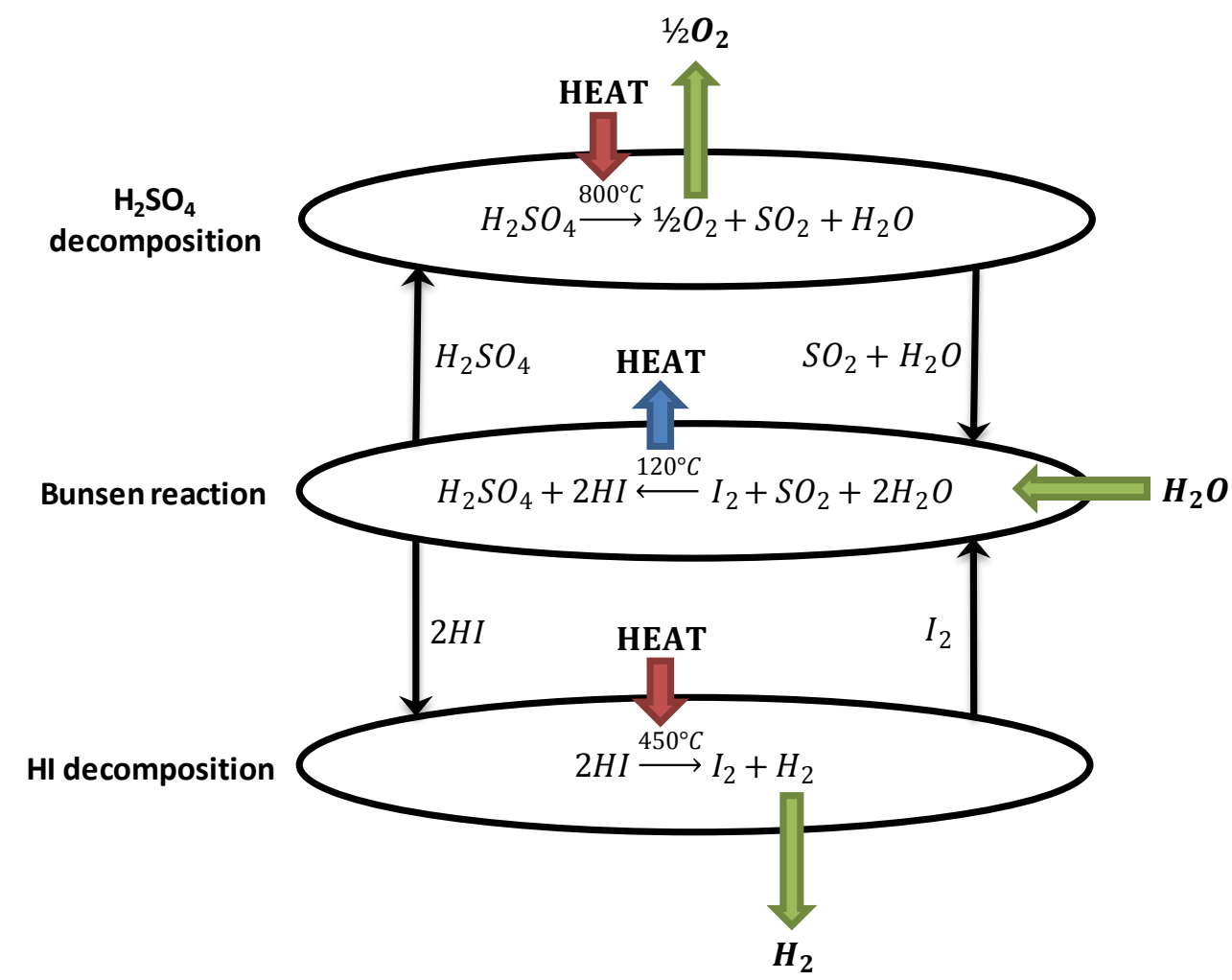

Figure 3: The Sulphur lodine cycle (Elder and Allen, 2009) 


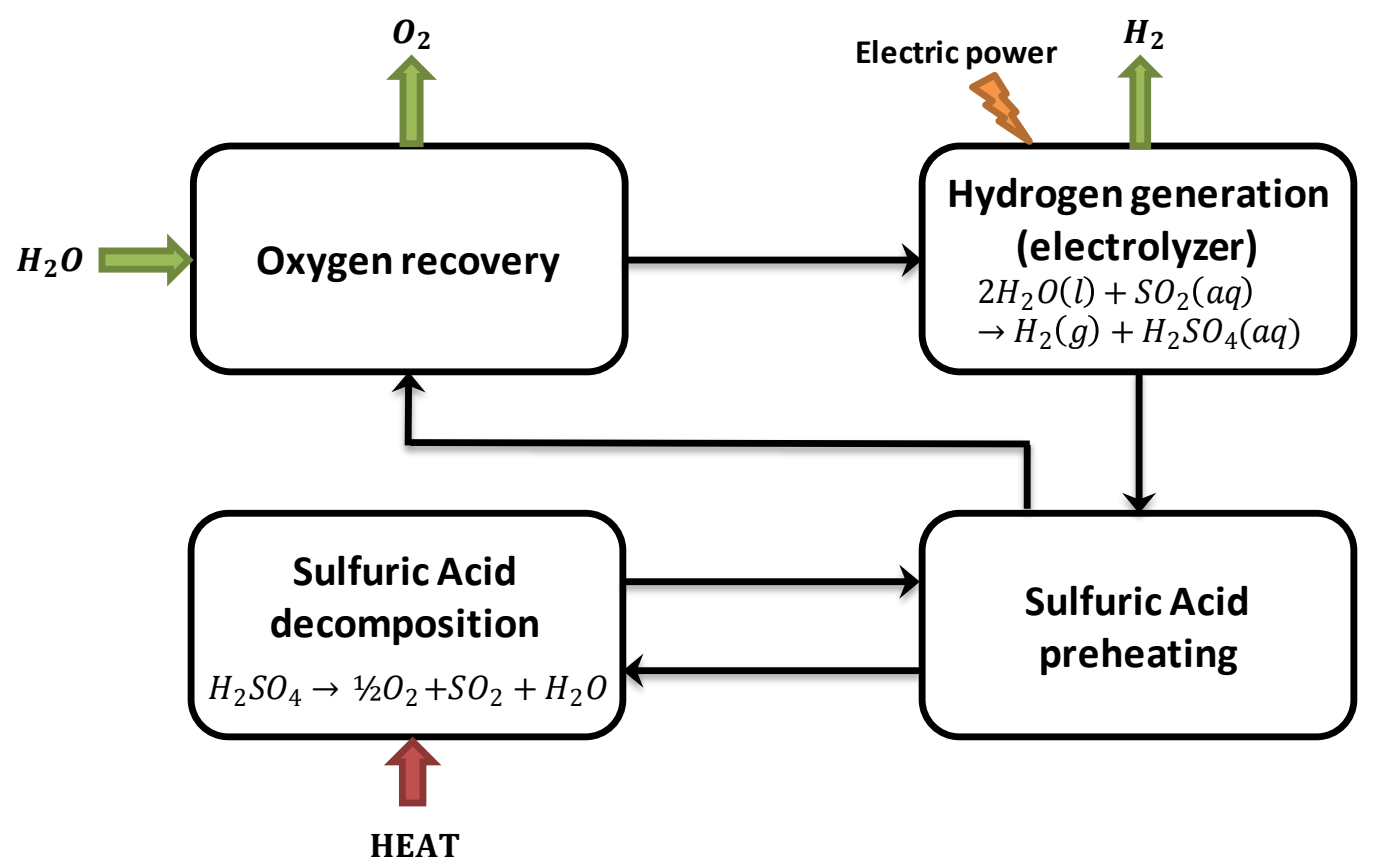

Figure 4: The hybrid sulphur cycle, with typical process conditions for a single module (Adapted from Lahoda et al., 2006)

\subsubsection{High Temperature Electrolysis}

At present, approximately $4 \%$ of the world's hydrogen is produced by low temperature water electrolysis, typically at temperatures below $100{ }^{\circ} \mathrm{C}$. Although this process is more than $80 \%$ efficient in converting electricity to hydrogen, it requires electricity, which can only be produced at an efficiency of around $40 \%$, resulting in an overall efficiency of approximately $35 \%$. However, by using high temperature steam at temperatures of $800{ }^{\circ} \mathrm{C}$ to $1000{ }^{\circ} \mathrm{C}$, the required electric energy for the electrolysis reaction can be decreased substantially, as shown in Figure 5. This figure shows how the ratio of electrical energy demand to total energy demand drops from about $93 \%$ at $100{ }^{\circ} \mathrm{C}$ to $70 \%$ at $1000{ }^{\circ} \mathrm{C}$. The decreasing electrical work requirement at higher temperatures for water splitting results in higher overall thermal-tohydrogen production efficiencies at higher temperatures. The modelling of a high temperature electrolysis (HTE) process in Japan (Fujiwara et al., 2008) reported process efficiencies of $53 \%$, at an operating temperature of $800{ }^{\circ} \mathrm{C}$, although this was only accomplished on a small scale. 




Figure 5: The variation in energy requirements to split water at different temperatures (O'Brien, 2008)

\subsection{Nuclear hydrogen cogeneration system}

As mentioned in section 2.1.3, one of the most promising routes for the large scale production of hydrogen, is to couple a high temperature nuclear heat source to a thermochemical cycle or high temperature electrolysis process (refer to Figure 2). In order to optimise energy efficiency, such a system lends itself ideally to a cogeneration concept. A typical HTR cogeneration plant would utilise the high temperature nuclear heat for hydrogen production, while the lower temperatures could be used for electricity and/or process heat production. The various components of such a cogeneration plant are discussed briefly in the following sections.

\subsubsection{High Temperature Gas Cooled Reactor}

The High Temperature Gas Cooled Reactor (HTGR or HTR) has been under development during the last 50 years. It evolved to the current design of using helium as coolant and graphite as moderator, both of which enhances neutron and thermal efficiencies. A key design feature of all HTR's, is the use of triple coated isotropic (TRISO) uranium fuel particles. These layers of carbon, along with a layer of silicon carbide, will contain potentially harmful nuclear products and effectively prevent any runaway chain reactions by maintaining critical 
spaces between fuel elements. This means that the reactor is inherently safe and will automatically shut itself down, even if the active cooling system fails.

There are currently five major HTR development consortiums in the world:

- Japan Atomic Energy Agency (JAEA), responsible for development of the High Temperature Engineering Test Reactor (HTTR) and GTHTR300 gas turbine electricity generation system.

- Tsinghua University's Institute of Nuclear Energy Technology (INET) near Beijing in China, that forms part of the Chinese national High Technology R\&D Programme, who developed and constructed the HTR-10 demonstration pebble bed HTR. In 2004, INET signed an agreement with a Chinese construction company to construct two 250 MW HTR's, using pebble bed modular technology. This project is known as the HTR-PM and is scheduled for commissioning by 2015.

- The Pebble Bed Modular Reactor (PBMR) has been developed since 1994 by Eskom and partners around the world. The South African Government funded the project until 2010, but a lack of investors led to the demise of the company and an abrupt halt to this development program.

- ANTARES is a French research partnership between AREVA NP, CEA and EDF, with the goal of developing an industrial HTR demonstration plant. All three partners are also involved in the RAPHAEL project, short for ReActor for Process heat, Hydrogen And Electricity generation Integrated Project. The RAPHAEL project was launched by the European Union in 2005.

- The Gas Turbine Modular Helium Reactor (GT-MHR) is being developed by General Atomics (GA).

HTR plants that were operated previously and those still under development, are listed in Table 2: 
Table 2: HTR plants - development and operation (adapted from Elder and Allen, 2009). Core structure: Cyl - Cylindrical, PB - Pebble bed, Hex - Hexagonal

\begin{tabular}{|l|l|c|c|l|l|}
\hline Reactor & Location & $\begin{array}{c}\text { Power } \\
(\mathbf{M W t})\end{array}$ & $\begin{array}{c}\text { He temp. } \\
\text { In/out } \\
\left({ }^{\circ} \mathbf{C}\right)\end{array}$ & Core & $\begin{array}{l}\text { Operation } \\
\text { years }\end{array}$ \\
\hline Dragon & UK & 20 & $350 / 750$ & Cyl & $1965-1975$ \\
\hline $\begin{array}{l}\text { Peach } \\
\text { Bottom }\end{array}$ & USA & 115 & $377 / 750$ & Cyl & $1967-1974$ \\
\hline AVR & Germany & 46 & $270 / 950$ & PB & $1968-1988$ \\
\hline Fort St Vrain & USA & 842 & $400 / 775$ & Hex & $1976-1989$ \\
\hline THTR & Germany & 750 & $270 / 750$ & PB & $1985-1989$ \\
\hline HTTR & Japan & 30 & $395 / 950$ & Hex & 1998 \\
\hline HTR-10 & China & 10 & $250-300 /$ & PB & 2000 \\
\hline PBMR & SA & 500 & $350 / 950$ & PB & Suspended \\
\hline ANTARES & France & 600 & $400 / 850$ & Hex & In development \\
\hline GT-MHR & USA/Russia & $550-$ & $490 / 950$ & Hex & In development \\
\hline HTR-PM & China & $2 \times 250$ & $250 / 750$ & PB & In development \\
\hline GTHTR300 & Japan & 600 & $589 / 850$ & Hex & In development \\
\hline
\end{tabular}

\subsubsection{Intermediate heat exchanger}

The intermediate heat exchanger $(\mathrm{IHX})$ is a critical piece of equipment in a HTR plant. It has to transfer large amounts of heat from the primary to the secondary loops at high efficiency. Due to the high operating temperatures, specialised materials are required. The IHX requires a large heat transfer area, while at the same time being compact enough to be housed in a single pressure vessel. In addition, it must prevent process gas entry into the reactor core, while also minimising hydrogen and tritium diffusion between the primary and secondary loops. Currently, no operational experience exists for the required size and operating conditions. The IHX therefore still requires major development and testing work and presents a huge engineering challenge.

An overview of the various design schemes for the $\mathrm{IHX}$ is presented in Figure 6 and Table 3. Helium at temperatures of between $850{ }^{\circ} \mathrm{C}$ to $950{ }^{\circ} \mathrm{C}$ is the heat transfer medium on the primary side, while the secondary loop will be helium if a direct Brayton cycle is used for power conversion and steam if a Rankine cycle is chosen for power conversion. The small temperature difference (or LMTD) across most heat exchanger configurations, will need a large heat transfer area and therefore a compact surface geometry is required. Due to its large surface area, a plate type heat exchanger is the only economically viable alternative in these cases. 


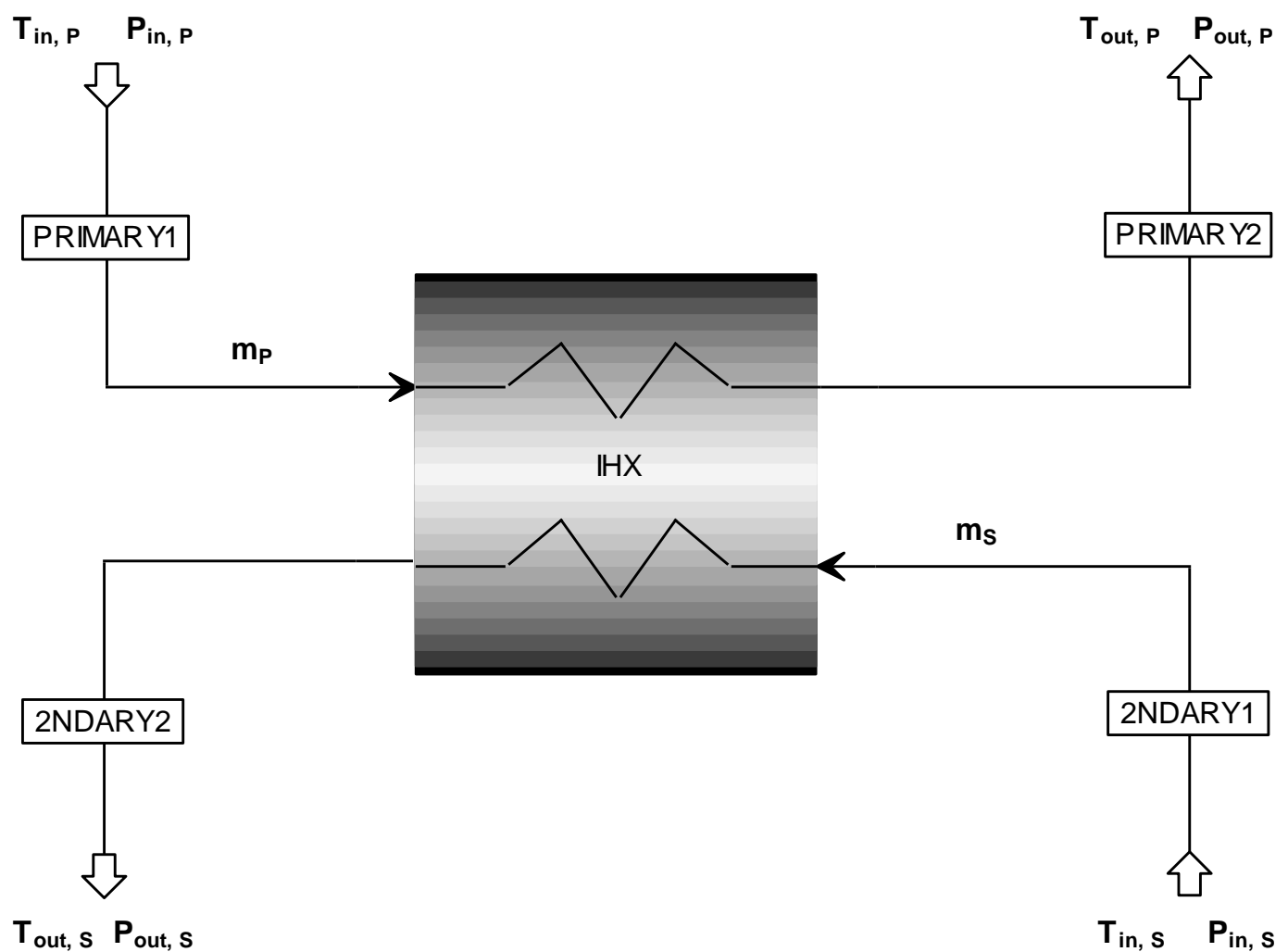

Figure 6: Intermediate Heat Exchanger schematics

Table 3: Intermediate heat exchanger parameters for different designs (adapted from Elder and Allen, 2009)

\begin{tabular}{|c|c|c|c|c|c|}
\hline Parameter & Unit & JAEA & $\begin{array}{l}\text { HYTHEC/ } \\
\text { RAPHAEL }\end{array}$ & AREVA & GA \\
\hline$m_{P}$ & $\mathrm{~kg} / \mathrm{s}$ & 324.2 & 209.95 & 240 & 321 \\
\hline $\mathbf{P}_{\mathrm{in}, \mathrm{P}}$ & ${ }^{\circ} \mathrm{C}$ & 950 & 950 & 850 & 950 \\
\hline$T_{\text {in, } P}$ & $\mathrm{MPa}$ & 5 & 5.5 & 5.5 & 7.03 \\
\hline$T_{\text {out }, P}$ & ${ }^{\circ} \mathrm{C}$ & 850 & 387 & 350 & 590 \\
\hline $\mathbf{P}_{\text {out }, P}$ & $\mathrm{MPa}$ & & 5.4 & & 7 \\
\hline $\mathrm{m}_{\mathrm{s}}$ & $\mathrm{kg} / \mathrm{s}$ & 80.3 & 218.89 & 614 & 321 \\
\hline$T_{\text {in }, S}$ & ${ }^{\circ} \mathrm{C}$ & 500 & 350 & 300 & 565 \\
\hline $\mathbf{P}_{\mathrm{in}, \mathrm{S}}$ & $\mathrm{MPa}$ & 5.15 & 5 & 5.5 & 7.1 \\
\hline$T_{\text {out }, S}$ & ${ }^{\circ} \mathrm{C}$ & 900 & 890 & 800 & 925 \\
\hline $\mathbf{P}_{\text {out }, \mathrm{S}}$ & $\mathrm{MPa}$ & & 4.9 & & 7.07 \\
\hline $\mathbf{Q}$ & $\mathrm{MW}_{\mathrm{t}}$ & 170 & 613.3 & 608 & 600 \\
\hline LMTD & ${ }^{\circ} \mathrm{C}$ & 154 & 48 & 50 & 24 \\
\hline \multicolumn{2}{|c|}{$\begin{array}{l}\text { Heat exchanger } \\
\text { design }\end{array}$} & $\begin{array}{l}\text { Helical } \\
\text { shell and } \\
\text { tube }\end{array}$ & - & $\begin{array}{l}\text { Plate } \\
\text { fin/tubular/ } \\
\text { printed circuit }\end{array}$ & $\begin{array}{l}\text { Printed } \\
\text { circuit }\end{array}$ \\
\hline
\end{tabular}




\subsubsection{Power conversion systems}

Almost all nuclear and coal power stations make use of the Rankine cycle. This cycle typically consists of a few main components, as shown in Figure 7. The process steps in a Rankine cycle with reheating and regeneration, can be described as follows:

- Step 13-1: The working fluid (water in typical coal and nuclear power stations) is pumped from low to high pressure.

- Step 1-2: The fluid is heated by an external heat source, such as a coal fired boiler or a nuclear reactor, to form a dry, saturated vapour.

- Step 2-3: The vapour expands through a turbine. The maximum inlet temperature for the turbine is approximately $565^{\circ} \mathrm{C}$, the creep limit of stainless steel.

- Step 4-5: Intermediate pressure steam from the first stage is sent back to the boiler where it is reheated at constant pressure, usually to the first turbine stage inlet temperature. Reheating is a critical step to prevent excessive moisture in turbines and is commonly utilised in steam power plants. Reheating improves the cycle efficiency by raising the average temperature at which heat is transferred to the steam.

- Step 5-6: The reheated vapour expands through a medium pressure turbine, which produces work by rotating a shaft connected to an electric generator.

- Step 7-8: The low pressure steam expands through a lower pressure turbine, which produces work by rotating a shaft connected to an electric generator.

- Step 8-9: The fluid is condensed at constant pressure and temperature.

- Step 10-11: Dissolved gasses in the feed water is released in the deaerator by mixing it with a bleed steam stream. Deaeration is necessary prevent corrosion in the boiler.

- Step 12-13: Heat is transferred from a bleed steam stream to the feed water in a feed water heater $(\mathrm{FWH})$ or regenerator. This step increases the cycle efficiency by increasing the average heat addition temperature in the boiler. 


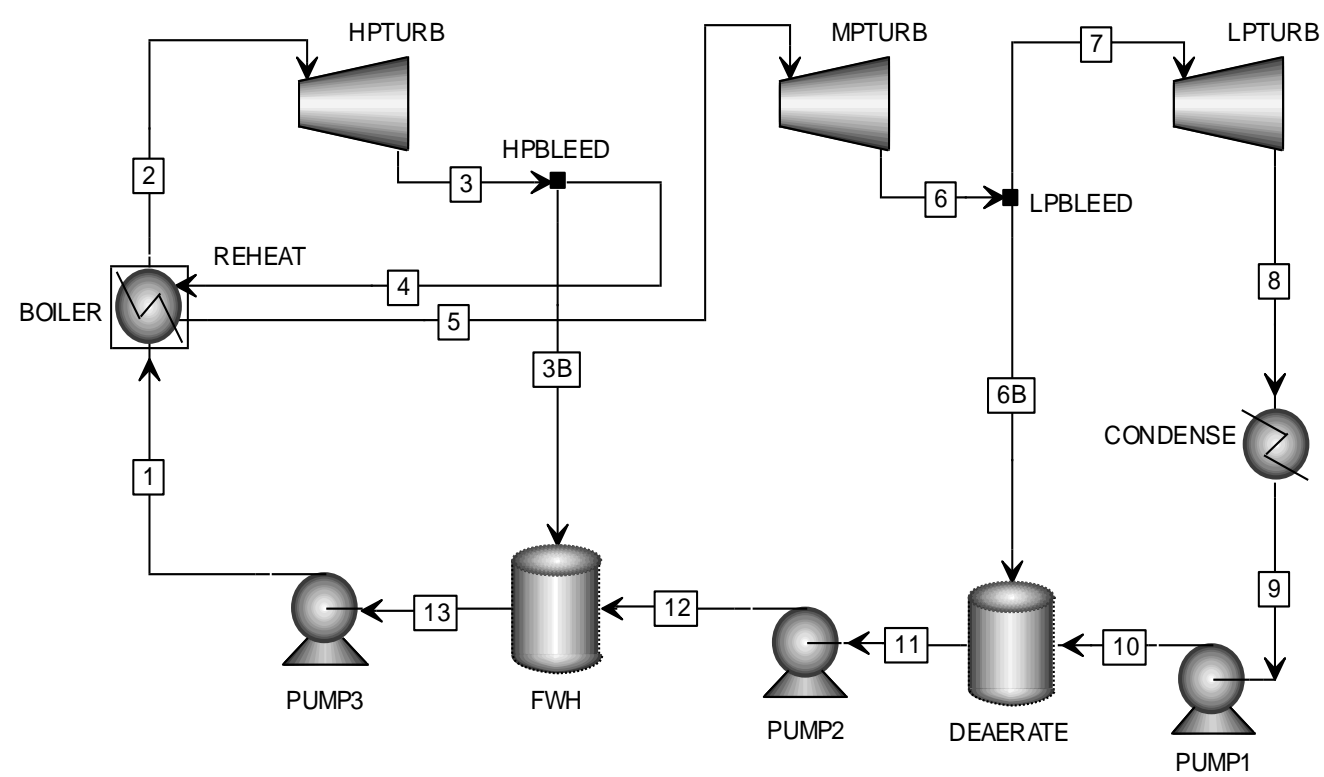

Figure 7: Process flow diagram of an ideal reheat-regenerative Rankine cycle (adapted from Çengel and Boles, 2011)

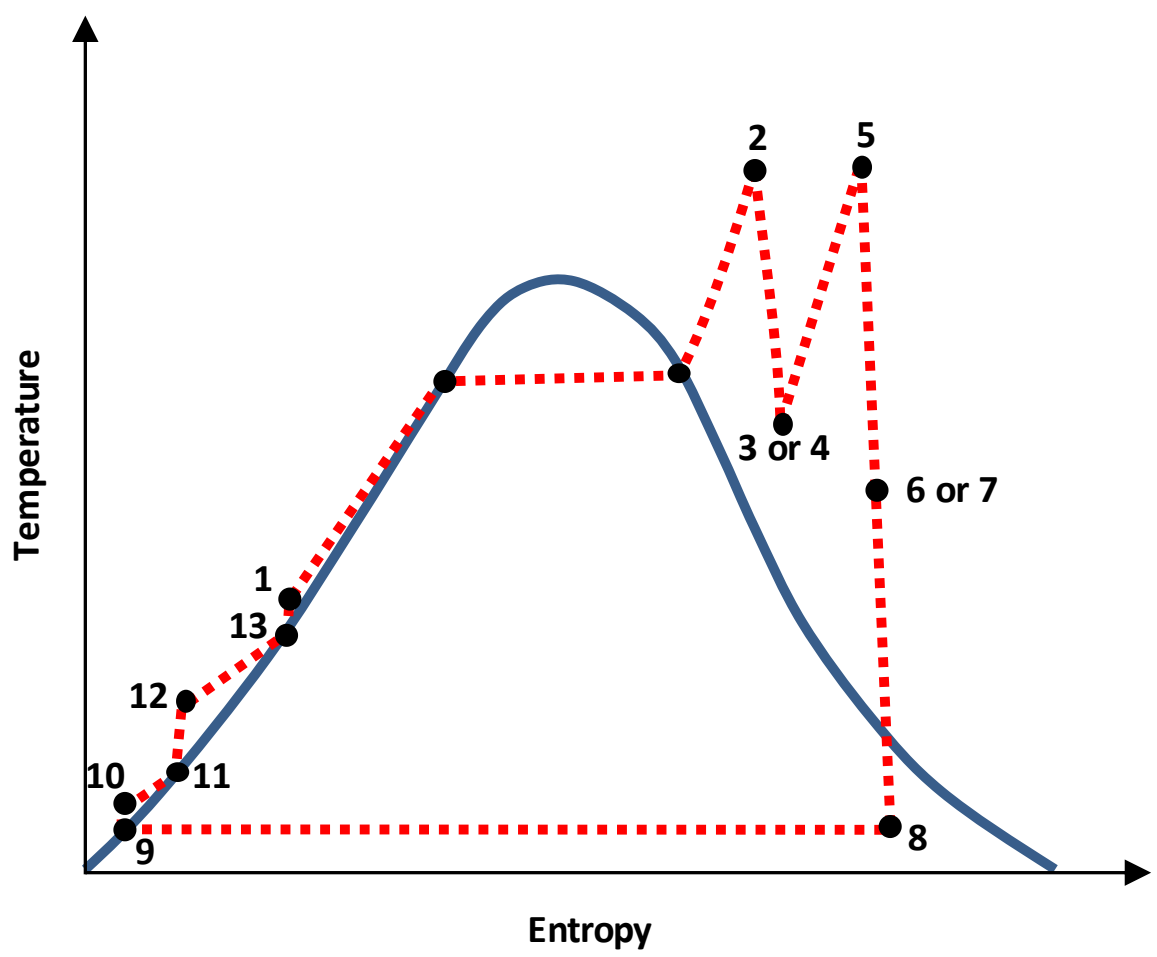

Figure 8: T-s diagram for an ideal reheat-regenerative Rankine cycle, similar to the process illustrated in Figure 7 (adapted from Çengel and Boles, 2011) 
The temperature entropy or T-s diagram for the Rankine cycle with superheat (in order to increase the efficiency of the cycle) is shown in Figure 8. Ideally, both the pump and turbine would be isentropic, but in reality, these processes are irreversible and generate entropy. The cycle efficiency depends on the difference between the heat supply and heat rejection temperatures, according to the Carnot principle. A conventional subcritical coal-fired power plant achieves a thermal efficiency of around $37 \%$ (Rezvani et al., 2007). Studies by Frohling et al. (2002), show that coupling an HTR to a Rankine cycle, will theoretically achieve efficiencies of $42 \%$, using predominantly proven technology. This improvement is possible mainly due to the HTR's higher heat supply temperatures compared to those of a conventional coal or nuclear power cycle.

Another option for converting heat into electricity is through a gas turbine or Brayton cycle. The coupling of a HTR to a Brayton cycle is not proven yet, although gas turbine technology is a well-established technology in other fields of application. The working fluid for the Brayton cycle is a gas, with helium being the most common working fluid for coupling a HTR to a Brayton cycle, due to its excellent heat transfer properties. The gas is heated first, before the turbine extracts work from the hot, pressurised gas. The gas is then cooled and compressed, before being pumped back to the HTR to act as core coolant.

\subsubsection{Nuclear hydrogen production plant}

All the HTR consortiums, except the Chinese, plan to couple a hydrogen production plant to their HTR. The Chinese HTR-10 and HTR-PM programmes, however, are focusing only on electricity generation. Although the reactor sizes are fairly similar for all the programmes, the choice of Power Conversion System (PCS), Hydrogen Production Plant (HPP) and Intermediate Heat Exchanger (IHX), differs substantially. The plant layout varies between direct or indirectly coupled PCS, with a HPP in series or parallel to the PCS. Preliminary calculations show that, regardless of the specific technology or configuration chosen, the predicted costs and thermal efficiency are very similar.

Another option would be to have separate nuclear plants for electricity generation and thermal coupling. A PBMR analysis of a such a separate configuration concluded that the maximum efficiency was achieved when only the HPP electrical power requirements was met, with no additional electricity production. This study also concluded that there is no significant difference in efficiency between using a Brayton cycle or a high pressure Rankine cycle. Table 4 gives an overview of the different nuclear hydrogen programmes: 
Table 4: Overview of nuclear hydrogen programmes (Elder and Allen, 2009)

\begin{tabular}{|l|l|l|l|l|}
\hline Company & JAEA & GA & $\begin{array}{l}\text { PBMR/ } \\
\text { Westinghouse }\end{array}$ & AREVA NP \\
\hline Country & Japan & USA & SA/USA & France \\
\hline Reactor & GTHTR300 & MHR-GT & PBMR & ANTARES \\
\hline $\begin{array}{l}\text { Power } \\
\text { (MW) }\end{array}$ & 600 & $550-600$ & 500 & 600 \\
\hline PCS & Brayton & Brayton & Rankine & Rankine \\
\hline HPP & SI & HTE/SI & HyS/HTE & HTE/SI \\
\hline $\begin{array}{l}\text { Cycle } \\
\text { config- } \\
\text { uration }\end{array}$ & $\begin{array}{l}\text { Direct PCS } \\
\text { series } \\
\text { indirect HPP }\end{array}$ & $\begin{array}{l}\text { Direct } \\
\text { PCS, } \\
\text { parallel } \\
\text { indirect } \\
\text { HPP }\end{array}$ & $\begin{array}{l}\text { Indirect, series } \\
\text { HPP and PCS }\end{array}$ & $\begin{array}{l}\text { Indirect, parallel } \\
\text { HPP and PCS }\end{array}$ \\
\hline IHX & $\begin{array}{l}\text { Helical coil } \\
\text { shell \& tube }\end{array}$ & $\begin{array}{l}\text { Single- } \\
\text { stage print } \\
\text { circuit } \\
\text { heat } \\
\text { exchanger } \\
\text { (PCHE) }\end{array}$ & $\begin{array}{l}\text { Two stage } \\
\text { PCHE }\end{array}$ & $\begin{array}{l}\text { PCS: Helical } \\
\text { coil shell \& tube. } \\
\text { Process: PCHE } \\
\text { or } \\
\text { fin plate }\end{array}$ \\
\hline
\end{tabular}

The cogeneration of hydrogen and electricity has been investigated in detail during the past decade by the various HTR consortiums. The main challenge is to create a flexible cogeneration ratio between hydrogen and electricity production. An example of such a cogeneration plant was examined in detail (Lahoda et al., 2006), which consists of four 500 MWt PBMR's, each coupled via an IHX and a secondary helium loop to a modular HyS plant. Each HyS plant consumes about $200 \mathrm{MWt}$, while the remaining $1200 \mathrm{MWt}$ was used to power a single Rankine steam cycle. The PCS utilised about $400 \mathrm{MWt}$ of low grade waste heat from the HyS units and generated about $600 \mathrm{MWe}$ at above $38 \%$ efficiency. The price of the hydrogen was estimated to be between $\$ 2$ and $\$ 3 / \mathrm{kg}$. A schematic of this process is shown in Figure 9.

\subsection{Coal-To-Liquids application}

Synthetic fuel offers a viable alternative to conventional oil and is expected to play an increasing role in the transportation fuel industry due to the depletion of the world's oil reserves. Synthetic fuel can be made from coal by means of an indirect coal liquefaction process, which is also known as the Coal-ToLiquid (CTL) process. 
$4 \times$ PBMR/HyS Processes

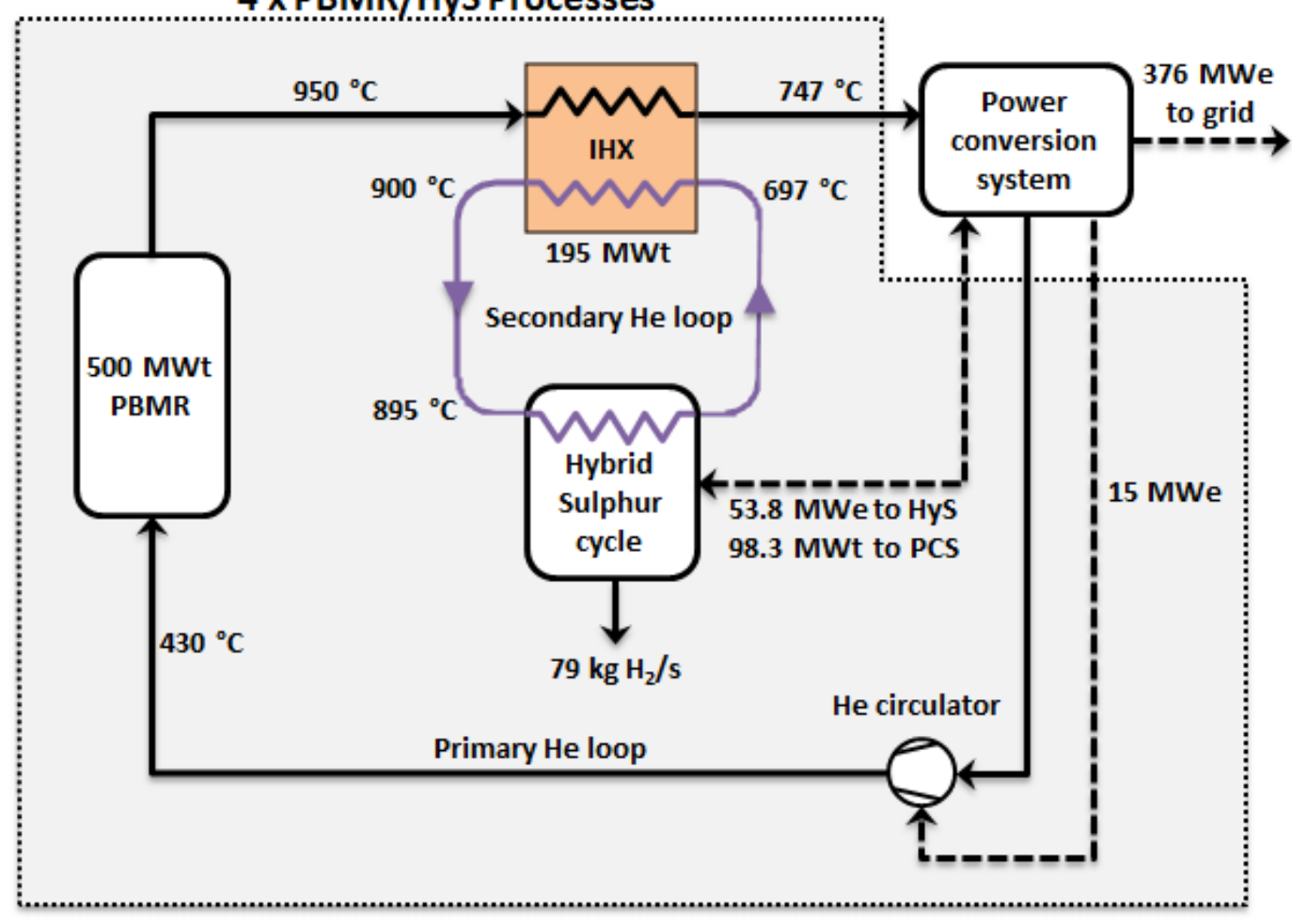

Figure 9: Block flow diagram of a cogeneration plant consisting of four PBMR's coupled to a HyS cycle and one Rankine steam cycle (Lahoda et al., 2006)

\subsubsection{The Coal-To-Liquids process}

In an indirect coal liquefaction process coal is gasified in the presence of steam and oxygen to produce a synthesis gas or so-called syngas consisting mainly of hydrogen and carbon monoxide. In the next step of the process, the sulphur and $\mathrm{CO}_{2}$ impurities are removed from the syngas. The cleaned syngas is then converted into synthetic fuels over a catalyst in a synthesis reactor. A typical indirect coal liquefaction process is shown in Figure 10.

Note that the correct $\mathrm{H}_{2} / \mathrm{CO}$ molar ratio plays a vital role in the synthesis gas conversion step and is therefore carefully manipulated by controlling the fraction of the gas stream that bypass the water-gas shift reactor. FischerTropsch synthesis is the most common process for producing hydrocarbons from synthesis gas and is currently utilised by Sasol in South Africa to produce the equivalent of 160000 barrels per day of fuels and petrochemicals, which constitutes in excess of $25 \%$ of South Africa's daily liquid fuel requirements (Eberhard, 2011). 


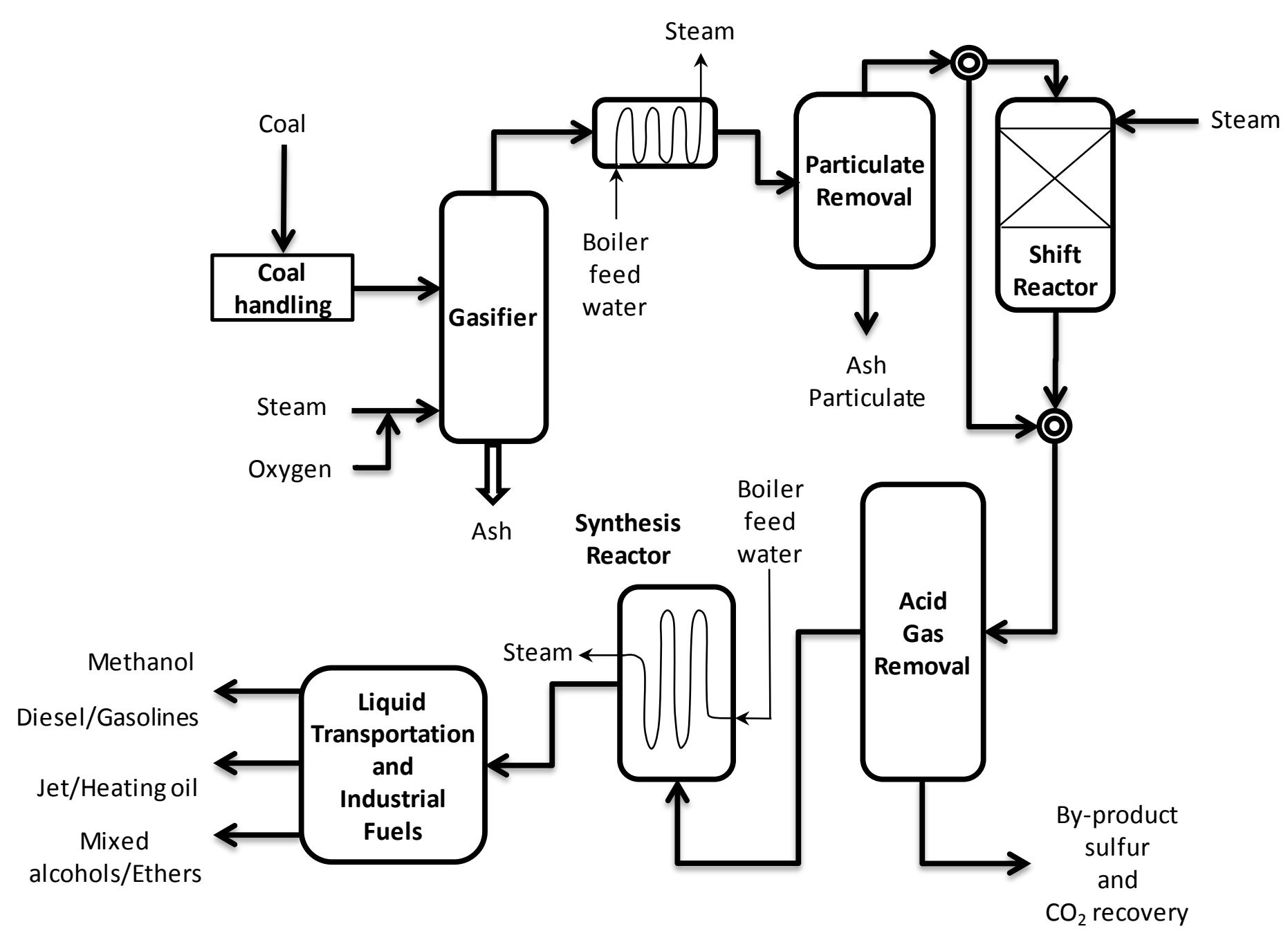

Figure 10: The indirect coal liquefaction process (Adapted from Perry et al., 2008:24-19). 


\subsubsection{Coupling of an HTR to a CTL-plant}

Greyvenstein et al. (2008) presented a compelling case for the marriage of a nuclear and CTL plant. Traditionally, a CTL plant uses coal as energy source to provide in its electricity and process steam needs, all at a massive $\mathrm{CO}_{2}$ production penalty. In addition, $\mathrm{CO}_{2}$ is also formed as result of the water-gas shift reaction in order to produce hydrogen. In 2008 for example, Sasol emitted 73.6 million tonnes (Mt) $\mathrm{CO}_{2}$, according to news reports (Sasol's $\mathrm{CO}_{2}$ emissions down, 2009). "In 2010, the gasification of coal and related processes, the supply of steam, electricity, water and effluent treatment for the petrochemicals businesses in Secunda, resulted in the direct emission of 47.2 Mt of the greenhouse gas, carbon dioxide, from Sasol Synfuels" (Sasol Annual Review 2010).

Assuming that production levels stayed constant in 2008, compared to 2010, the $\mathrm{CO}_{2}$ emissions from the Sasol Synfuels complex at Secunda in South Africa was responsible for about $5.3 \%$ of the total $\mathrm{CO}_{2}$ emissions of the whole African continent $(890 \mathrm{Mt})$ and $14 \%$ of the total South African $\mathrm{CO}_{2}$ production (337.42 Mt), if compared to 2008 data (IEA, 2010). The company intended to reduce its "emissions intensity by $15 \%$ in all its operations by 2020 from a 2005 baseline" (Sasol's $\mathrm{CO}_{2}$ emissions down, 2009).

If a $\mathrm{CO}_{2}$-free alternative source of hydrogen and energy was available, a CTLplant could reduce its $\mathrm{CO}_{2}$ production substantially. This implies that Sasol Synfuels alone could make South Africa compliant to the requirements of the Kyoto Protocol. The hydrogen and oxygen demands of a CTL-plant could be met (at least partially) by coupling an HTR to a CTL-plant. This would result in a reduction of capital cost to the CTL-plant through the reduction in air separation units, as well as provide a valuable source of hydrogen, which will enable optimisation of the CTL-processes.

Another important benefit would be the reduction of coal consumption by the CTL-facility, which would conserve valuable fossil fuels and extend the life of the CTL-complex significantly. Various studies have been done to analyse possible flow schemes for a nuclear assisted syngas production from coal process by the Idaho National Laboratory (INL) (Harvego et al., 2008). The integrated process flow scheme as proposed by Greyvenstein et al., (2008) for coupling a PBMR to a CTL-plant is shown in Figure 11. 


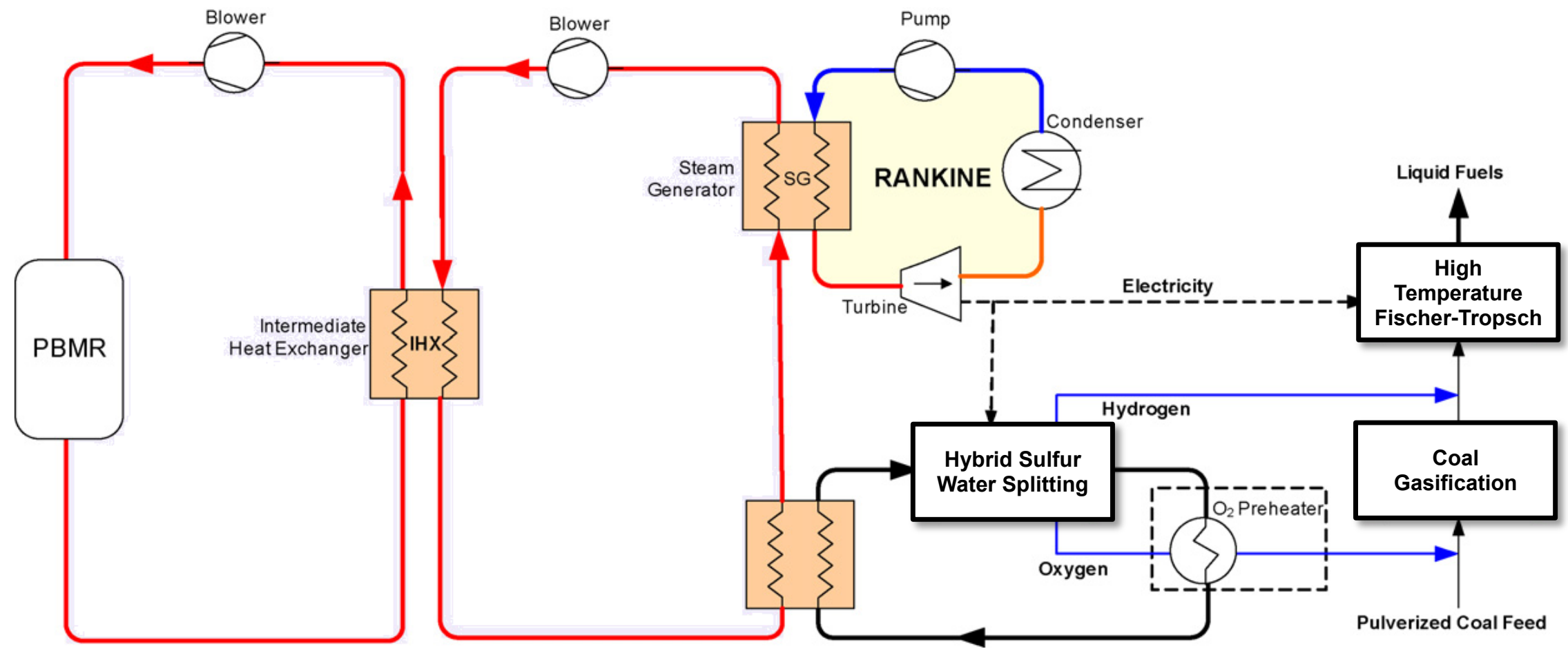

Figure 11: A proposed flow scheme for a PBMR hydrogen production plant coupled to a CTL-plant (Greyvenstein et al., 2008) 


\subsection{Exergy analysis}

Traditionally, scientists and engineers have used energy (or enthalpy) balances to quantify the energy efficiency of thermal and chemical processes. However, the causes of the majority of irreversibilities in thermal and chemical processes cannot be detected by an energy or enthalpy balance (known as a first law analysis). For instance, irreversible heat transfer, throttling and adiabatic combustion are not seen as energy losses, but they actually lead to exergy losses and therefore a loss in work potential of the available energy source. All exergy losses therefore amount to additional energy sources and/or capital investment costs requirements. For this reason, an exergy balance is essential to accurately determine the efficiency of a thermal or chemical process. An exergy analysis or so-called second law analysis can detect and quantify the causes of thermodynamic irreversibilities in a process and give guidance on how to improve the energy efficiency of a process. However, the practicality and economic feasibility of these energy efficiency improvements can only be determined by other evaluation methods.

\subsubsection{Definition of exergy}

The second law of thermodynamics is based on the work of Sadi Carnot. In 1824, Carnot studied the improvements for steam engines by James Watt and concluded that there are limitations on the conversion of heat into work by a heat engine. He demonstrated that this conversion process depended on the temperature at which the heat is available or the quality of the heat. In thermodynamics, the exergy of a system is defined as the maximum useful work possible during a process that brings the system into equilibrium with a heat reservoir (Perrot, 1998) The word "exergy" was proposed by Rant (Rant, 1956) for this purpose. Other terms are "available energy", "usable energy", "work potential" and "availability".

The maximum work is obtained when the stream is brought reversibly to equilibrium. In practice, however, many thermal and chemical processes are irreversible and therefore generates entropy. Turbines, for example, do not perform isentropically and maximum isentropic efficiencies of around $90 \%$ can be obtained in steam turbines. In other words, $10 \%$ of the steam's work potential or exergy is lost in the expansion process through a typical steam turbine. Szargut (1998) gives a detailed explanation of the theory concerning the concept of exergy. This theory may be summarised as follows:

Exergy is closely related to the Gibbs energy. The Gibbs Free Energy is defined as:

and

$$
g=h-T s
$$

$$
d g=d h-T d s-s d T
$$


At isothermal conditions $(s d T=0)$ at the reference temperature $\left(T_{0}\right)$ and pressure $\left(P_{0}\right)$ the change in Gibbs energy, $\Delta g_{0}$, equals the change in exergy, $\Delta \mathrm{x}$ :

$$
\Delta g_{0}=\Delta h_{0}-T_{0} \Delta s_{0}=\Delta x
$$

The change in Gibbs energy is a measure of work potential at isothermal change of state:

$$
\Delta g=\Delta h-T \Delta s
$$

Exergy is a measure of work potential at any change of state, relative to a reference state:

$$
\Delta x=\Delta h-T_{0} \Delta s
$$

\subsubsection{Exergy transfer}

Exergy, like energy, can be transferred from one system to another in the form of work, heat or mass flow. Heat is a form of disorganised energy and only a fraction of it can be converted to work, which is a form of organised energy, according to the second law of thermodynamics. The exergy transfer by heat (Q) at temperature $T$, in an environment at temperature $T_{0}$, is as follows (Çengel and Boles, 2011: 437)

$$
X_{\text {heat }}=\left(1-\frac{T_{0}}{T}\right) Q
$$

Exergy is work potential and therefore the work is equal to exergy transfer:

$$
X_{\text {work }}=W
$$

Mass contains exergy and mass flow is a way to transfer exergy:

$$
\begin{gathered}
X_{\text {mass }}=m \varphi \\
\text { with } \varphi=\left(h-h_{0}\right)-T_{0}\left(s-s_{0}\right)+\frac{V^{2}}{2}+g z
\end{gathered}
$$

\begin{tabular}{|c|c|c|c|c|c|c|}
\hline $\begin{array}{c}\text { Total } \\
\text { exergy } \\
\text { entering }\end{array}$ & - & $\begin{array}{l}\text { Total } \\
\text { exergy } \\
\text { leaving }\end{array}$ & - & $\begin{array}{c}\text { Total } \\
\text { exergy } \\
\text { destroyed }\end{array}$ & $=$ & $\begin{array}{l}\text { Change in } \\
\text { total exergy } \\
\text { of the } \\
\text { system }\end{array}$ \\
\hline$X_{\text {in }}$ & - & $X_{\text {out }}$ & - & $X_{\text {destroyed }}$ & $=$ & $\Delta X_{\text {system }}$ \\
\hline
\end{tabular}

The nature of exergy is contrary to that of entropy, since it cannot be it created, but can only be destroyed. The exergy balance of a closed system can thus be expressed as follows (Çengel and Boles, 2011: 441): 


\section{Simulation}

A simulation of the proposed cogeneration plant was developed to evaluate the thermal and carbon efficiency of this concept. The first step was to develop a process model for each section of the cogeneration plant, based on literature (refer to Figure 9 and Figure 11). After validating each model, the different sections were coupled in a practical and energy efficient way to form an integrated unit. The cogeneration plant concept is shown in Figure 12.

\subsection{Design basis}

Due to the complex nature of a process plant, a design basis for the process was established to limit the focus of this study to the relative project objectives. The design basis of the proposed cogeneration concept is the following:

- The design aspects of the nuclear reactor is outside the scope of this project and it was assumed that a high temperature nuclear gas cooled reactor (such as the Chinese HTR-PM concept) is feasible and able to deliver high temperature, reliable energy.

- Proven technology was used wherever possible. A mature subcritical Rankine cycle was chosen, based on the HTR-PM concept. In the case of developing technologies like the HTR and hydrogen production plant, technologies close to commercialization were chosen, using realistic thermal efficiencies.

- Typical South African coal and entrained flow gasifier yields were incorporated into the simulation model.

- The economic analysis of the cogeneration plant was outside the scope of the project, although it would play a significant role in the ultimate design of a process plant. It was therefore assumed that an economic optimum would result if the the air separation unit of a typical gasification plant was eliminated. This required that the water splitting process had to be sized to supply in the gasifier's oxygen requirement.

- All hydrogen produced was used to adjust the synthesis gas (syngas) $\mathrm{H}_{2} / \mathrm{CO}$ ratio to 2 , as required by the Fischer-Tropsch process.

- It was assumed that the intermediate heat exchanger could effectively prevent tritium migration through the heat exchanger, which enabled the direct use of steam from the Rankine cycle as process utility.

The following simulation method was adopted to answer the thesis objective:

- Simulate the proposed process flow scheme in accordance with the preceding design baseline using the commercial process simulation software Aspen Plus $®$ (2009). Refer to Appendix D for more detail on the specific simulation parameters that were used in the simulations. 


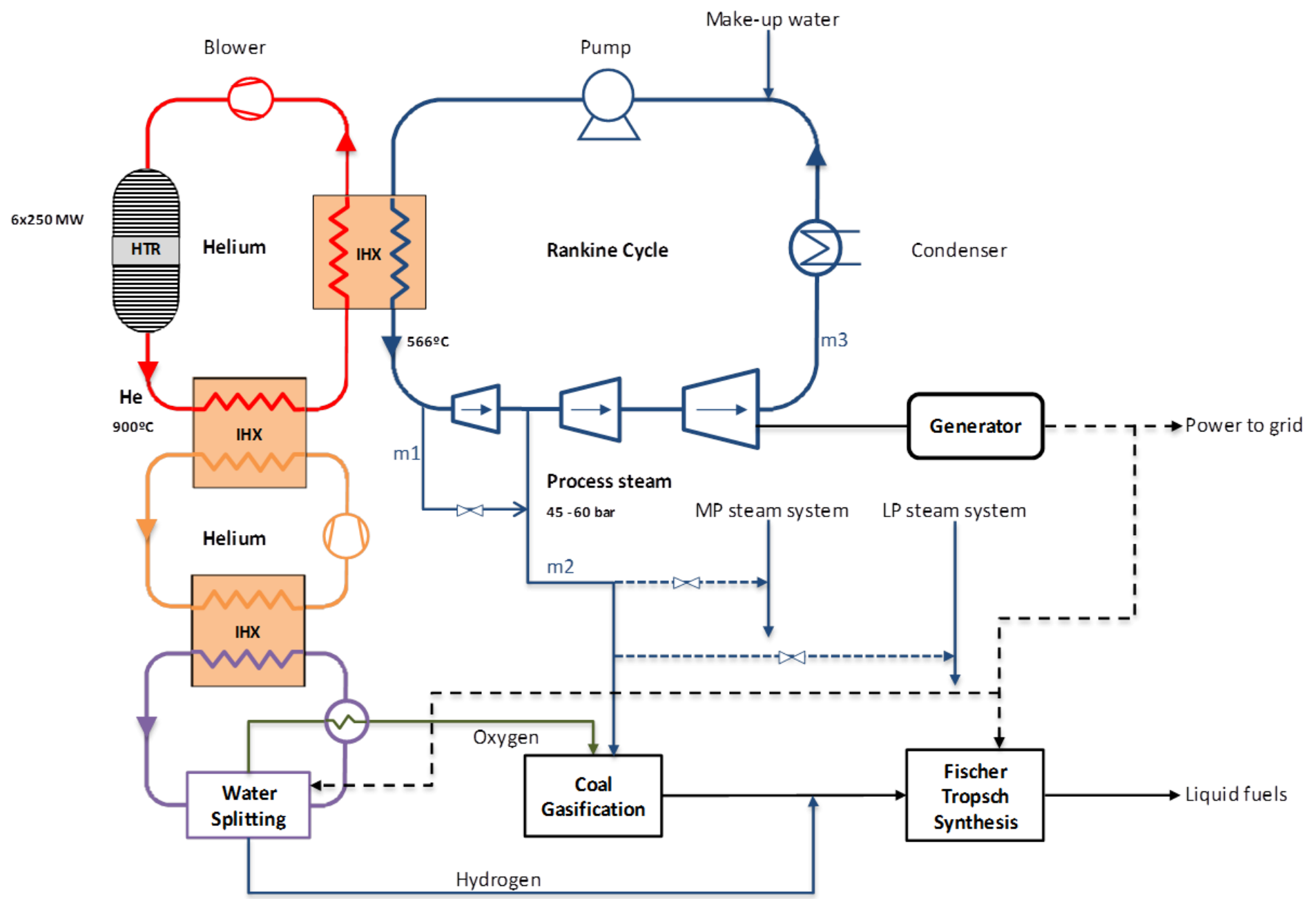

Figure 12: Proposed HTR cogeneration plant coupled to a Coal-To-Liquids (CTL) facility 
- Determine the thermal efficiency, exergy efficiency and carbon utilization of the proposed concept and compare different flow schemes in terms of the calculated thermal and carbon efficiencies.

The detail of each cogeneration plant section and its specific technology is discussed in more detail in subsequent paragraphs.

\subsection{Gasification unit}

Gasification can be defined as the production of combustible gases from carbonaceous fuels. Coal gasification is therefore the conversion of coal into gas with usable heating value.

\subsubsection{The gasification process}

The gasification process involves extremely complex chemistry, which is well documented in literature. Some of the most important gasification reactions are listed in Table 5:

Table 5: Chemical reactions in coal gasification (adapted from Perry et al., 2008)

\begin{tabular}{|c|c|c|}
\hline Reaction & Reaction heat (kJ/kmol) & Process \\
\hline \multicolumn{3}{|c|}{ Solid-gas reactions } \\
\hline 1.C $+\mathrm{O}_{2} \rightarrow \mathrm{CO}_{2}$ & +393790 & Combustion \\
\hline $2 . \mathrm{C}+2 \mathrm{H}_{2} \rightarrow \mathrm{CH}_{4}$ & +74900 & Hydrogasification \\
\hline 3. $\mathrm{C}+\mathrm{H}_{2} \mathrm{O} \rightarrow \mathrm{CO}+\mathrm{H}_{2}$ & -175440 & Steam-carbon \\
\hline $4 . \mathrm{C}+\mathrm{CO}_{2} \rightarrow 2 \mathrm{CO}$ & -172580 & Boudouard \\
\hline \multicolumn{3}{|c|}{ Gas-phase reaction } \\
\hline $5 . \mathrm{CO}+\mathrm{H}_{2} \mathrm{O} \rightarrow \mathrm{H} 2+\mathrm{CO}_{2}$ & +2853 & Water gas shift \\
\hline $6 . \mathrm{CO}+3 \mathrm{H}_{2} \rightarrow \mathrm{CH}_{4}+\mathrm{H}_{2} \mathrm{O}$ & +250340 & Methanation \\
\hline \multicolumn{3}{|c|}{ Pyrolysis and hydropyrolysis } \\
\hline \multicolumn{2}{|c|}{ 7. $\mathrm{CH}_{x} \rightarrow(1-x / 4) \mathrm{C}+(x / 4) \mathrm{CH}_{4}$} & Pyrolysis \\
\hline \multicolumn{2}{|c|}{ 8. $\mathrm{CH}_{x}+m \mathrm{H}_{2} \rightarrow[1-(x+2 m) / 4] \mathrm{C}+[(x+2 m) / 4] \mathrm{CH}_{4}$} & Hydropyrolysis \\
\hline
\end{tabular}

The endothermic steam-carbon and Boudouard reaction (reaction 3 and 4) is responsible for the conversion of carbon to combustible gases, while the heat energy for these endothermic reactions is supplied by the highly exothermic combustion reaction (reaction 1). The carbon monoxide and hydrogen produced in the gasification process also react with each other and with carbon in the water-gas shift and methanation reactions (reaction 5 and 6), both of which contribute to the heat requirement of the process. The extent of the steam-carbon and Boudouard reactions are therefore controlled by the equilibrium of the water gas shift reaction. 
In most cases, the gasification process is described fairly accurately by assuming thermodynamic equilibrium for the main gaseous species and carbon (see reactions 1 to 6). However, an exception is the moving-bed gasifier, where the prevalence of pyrolysis reactions in the cooler upper part of the reactor makes this approach inadequate. Pyrolysis or devolatilization is the thermal decomposition of coal which occurs as it enters the gasification zone of the gasifier. This pyrolysis process takes place at lower temperatures (350 to $800^{\circ} \mathrm{C}$ ) and produces a wide range of hydrocarbons, including coal char, phenols, tars and gases. The sequence of the gasification reactions is illustrated in Figure 13.

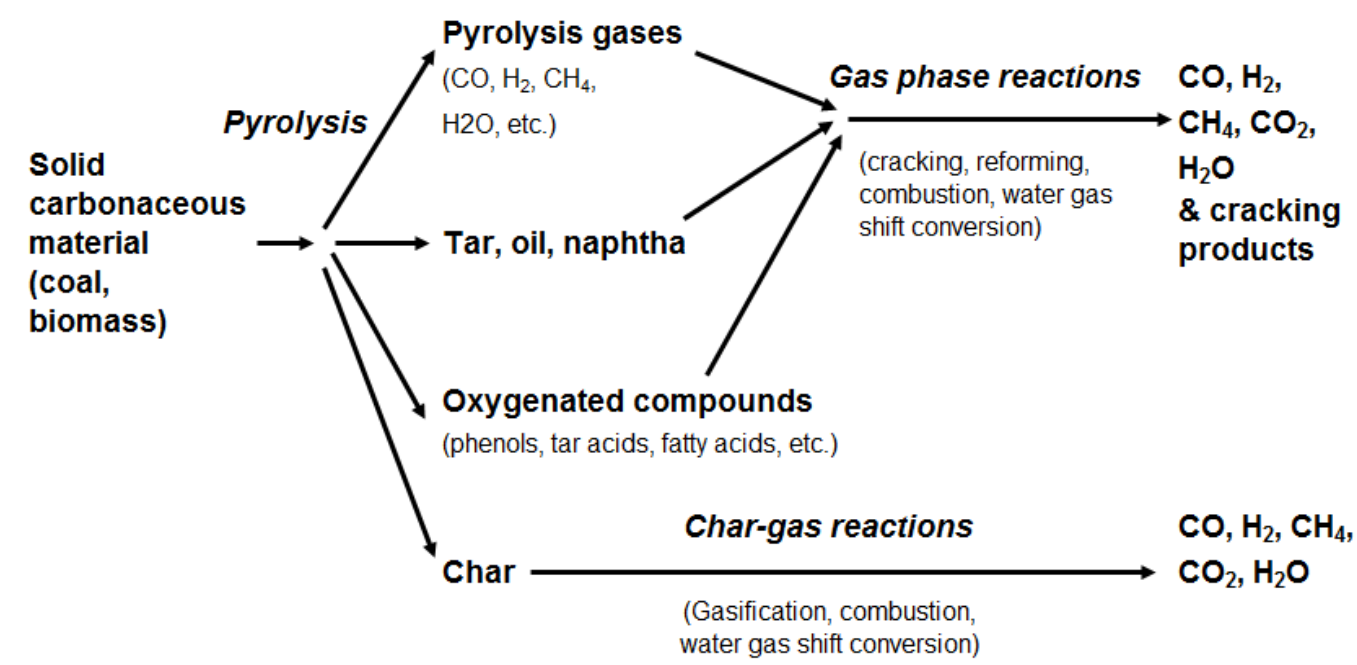

Figure 13: Reaction sequence for the gasification of coal (adapted from Higman et al., 2003)

\subsubsection{Types of gasifiers}

Although a wide variety of gasifiers are used in industrial applications, they can be grouped into three main categories. The characteristics of each type of gasifier is compared in more detail in Table 6.

Moving-bed gasifiers operate on lump coal (with particle size of 2 to $50 \mathrm{~mm}$ ) and have a coal bed that moves slowly downward by gravity. Steam and air or oxygen are generally blasted counter-currently through the bed. Dry ash is removed from the bottom of the gasifier.

Fluid-bed gasifiers accepts finely ground coal and mixes it very well with the oxidant. This ensures an even distribution in the whole bed. Unfortunately this may result in unreacted carbon in the ash that is removed, which limits the carbon conversion of this type of gasifier.

Entrained-flow gasifiers operate with a fine coal feed and gasifying agent (consisting of a steam and oxygen mixture) being blasted cocurrently into the gasifier. High temperatures are required due to the very short residence time, meaning that all entrained flow gasifiers operate in the ash slagging range. 


\subsubsection{Gasifier technology selection}

The choice of gasification technology will have a major influence on the viability and thermodynamic efficiency of the cogeneration plant and therefore the outcome of this study. The chosen technology therefore had to meet the following criteria:

- The technology had to be commercially proven

- Capable of handling the high ash content in typical South African coal. According to Eberhard (2011), ash contents vary, but can be up to $65 \%$ ash in the Waterberg coal fields. Eskom's coal-fired power stations in Mpumalanga use coal with an average ash content of $29.5 \%$, while Sasol consumes about 44 million tonnes per annum of $35 \%$ ash in its Secunda plants.

- Maximum carbon utilisation in the gasifier and therefore low $\mathrm{CO}_{2}$ content in the product synthesis gas.

The technologies considered were the Sasol-Lurgi dry bottom process, the British Gas/Lurgi (BGL) slagging gasifier and the Shell entrained flow coal gasification process. According to Higman et al. (2003), the reasons for the use of Lurgi gasifiers in the Sasol complex in South Africa are that it was the only pressurised gasifier available at the time and was also suitable for the high ash-melting coals of the area. One of the main advantages of the SasolLurgi gasifiers in a CTL complex is the production of a wide range of high value pyrolysis products. However, the capital investment and added complexity associated with the processing plants for pyrolysis products may be seen as disadvantages of the Sasol-Lurgi gasification process. Unfortunately, the product gas contains around $30 \% \mathrm{CO}_{2}$, which was the deciding factor not choosing Sasol-Lurgi technology for this study.

The British Gas/Lurgi (BGL) slagging gasifier was originally developed as a slagging version of the Lurgi gasifier. This gasifier was successfully commercialised and has the following benefits compared to the original Lurgi gasifier:

- Higher $\mathrm{H}_{2}$ and $\mathrm{CO}$ yields (with corresponding lower $\mathrm{CO}_{2}$ and $\mathrm{CH}_{4}$ production)

- Increased synthesis gas production

- Suitable for low ash-melting point coals

- Able to accept fine coal

- Lower steam consumption and therefore condensate production

Unfortunately, high ash-melting point coals require a fluxing agent like limestone in order to ensure a freely draining ash slag. This fact limits the maximum ash content that can be handled by the BGL gasifier and makes it unsuitable for the high ash levels in some South African coal fields. 
Table 6: Characteristics of different gasifier types (adapted from Higman et al., 2003)

\begin{tabular}{|c|c|c|c|c|c|}
\hline \multirow{3}{*}{$\begin{array}{l}\text { Category } \\
\text { Ash conditions } \\
\text { Typical processes }\end{array}$} & \multicolumn{2}{|l|}{ Moving-bed } & \multicolumn{2}{|l|}{ Fluid-bed } & \multirow{3}{*}{\begin{tabular}{|l|} 
Entrained-flow \\
Slagging \\
Shell, Texaco, \\
Koppers-Totzek, \\
Siemens, \\
Mitsubishi Heavy \\
Industries
\end{tabular}} \\
\hline & Dry bottom & Slagging & Dry ash & Agglomerating & \\
\hline & Lurgi & $\begin{array}{l}\text { British Gas } \\
\text { Lurgi }\end{array}$ & $\begin{array}{l}\text { Winkler, KBR } \\
\text { Kellogg Brown and } \\
\text { Root }\end{array}$ & $\begin{array}{l}\text { Kellog Rust } \\
\text { Westinghouse }\end{array}$ & \\
\hline \multicolumn{6}{|l|}{ Feed characteristics } \\
\hline Size & 6 to $50 \mathrm{~mm}$ & 6 to $50 \mathrm{~mm}$ & 6 to $10 \mathrm{~mm}$ & 6 to $10 \mathrm{~mm}$ & $<100 \mu \mathrm{m}$ \\
\hline Acceptability of fines & Limited & $\begin{array}{l}\text { Inject through } \\
\text { tuyères }\end{array}$ & Good & Better & Unlimited \\
\hline $\begin{array}{l}\text { Acceptability of caking } \\
\text { coal }\end{array}$ & $\begin{array}{l}\text { Yes } \\
\text { (with stirrer) }\end{array}$ & $\begin{array}{l}\text { Yes } \\
\text { (with stirrer) }\end{array}$ & Possibly & Yes & Yes \\
\hline Preferred coal rank & Any & High & Low & Any & Any \\
\hline \multicolumn{6}{|l|}{ Operating features } \\
\hline Outlet gas temperature & $\begin{array}{l}\text { Low } \\
\left(425 \text { to } 650^{\circ} \mathrm{C}\right)\end{array}$ & $\begin{array}{l}\text { Low } \\
\left(425 \text { to } 650^{\circ} \mathrm{C}\right)\end{array}$ & $\begin{array}{l}\text { Moderate } \\
\left(900 \text { to } 1050^{\circ} \mathrm{C}\right)\end{array}$ & $\begin{array}{l}\text { Moderate } \\
\left(900 \text { to } 1050^{\circ} \mathrm{C}\right)\end{array}$ & $\begin{array}{l}\text { High } \\
\left(1250 \text { to } 1600^{\circ} \mathrm{C}\right)\end{array}$ \\
\hline Oxidant demand & Low & Low & Moderate & Moderate & High \\
\hline Steam demand & High & Low & Moderate & Moderate & Low \\
\hline Other characteristics & $\begin{array}{l}\text { Hydrocarbons } \\
\text { in gas }\end{array}$ & $\begin{array}{l}\text { Hydrocarbons } \\
\text { in gas }\end{array}$ & $\begin{array}{l}\text { Lower carbon } \\
\text { conversion }\end{array}$ & $\begin{array}{l}\text { Lower carbon } \\
\text { conversion }\end{array}$ & $\begin{array}{l}\text { Pure gas, high } \\
\text { carbon conversion }\end{array}$ \\
\hline
\end{tabular}


Contrary to the moving-bed and fluid-bed gasifiers, entrained-flow gasifiers can handle virtually all types of coals, as long as it is ground to the required fine particle size. High-ash coals are not preferred due to the additional thermal load to melt the ash, which comes with a penalty in oxygen consumption. In general, the economic limit for dry feed entrained-flow gasifiers is $40 \%$ ash content in its coal feed, while this figure decreases to about $20 \%$ for slurry-feed entrained-flow gasifiers. The decrease in cold gas efficiency with higher ash content is shown in Figure 14. Note that a gasifier's cold gas efficiency is defined as the percentage of energy of the coal that ends up in the product gas.

Entrained-flow gasifiers are slagging type processes, which means that the operating temperature is higher than the ash melting point. This guarantees the destruction of all pyrolysis products and a carbon conversion in excess of $99 \%$. The ash leaves the reactor as an inert, glassy slag or frit, virtually stripped of all carbon. An interesting characteristic of single-stage, dry coal feed entrained flow gasifiers, is that the product gas composition is insensitive to coal quality, although the gas yield will suffer due to the ballast of high ash and water content in the coal. The product yield of dry coal feed entrained-flow gasifiers for a variety of coals and their analysis, are shown in Table A-1 and Table A-2 in Appendix A.

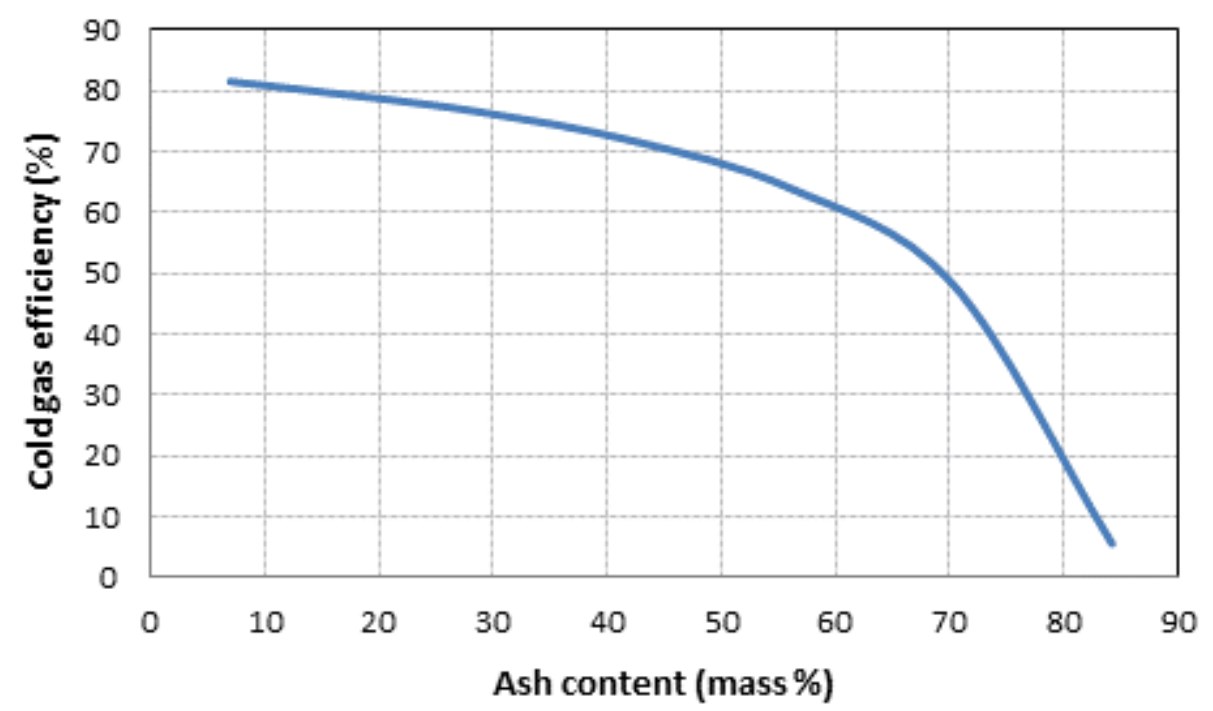

Figure 14: Entrained-flow gasifier efficiency as function of the coal ash content (adapted from Higman et al., 2003:123) 

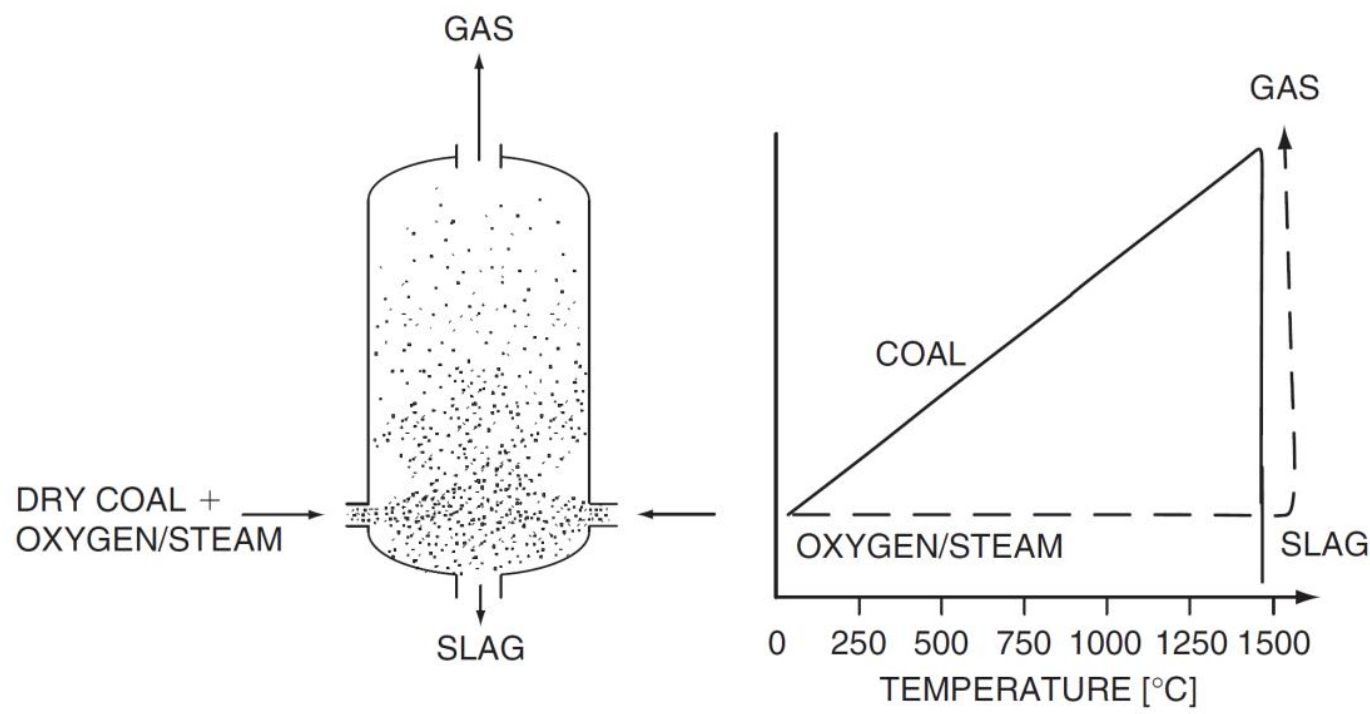

Figure 15: Side-fired dry coal feed slagging entrained-flow gasifier (Higman et al., 2003:122)

The low $\mathrm{CO}_{2}$ content in the product gas of a dry feed entrained-flow gasifier implies very high carbon utilisation in the gasification process and is ideal to couple with a hydrogen production plant and a WGS unit, both of which can serve to adjust the $\mathrm{H}_{2} / \mathrm{CO}$ ratio in the product gas to the required ratio of 2 for the Fischer-Tropsch process. According to the IEA GHG Report (IEA GHG Report PH4/19, 2003: Section H1), entrained flow gasifiers have been selected for nearly all recent gasification projects due to their ability to process a large variety of fuels, as well as the fact that they can achieve economy of scale in large single trains. The preferred gasification technology for this study is therefore the commercially proven Shell dry feed entrained-flow gasification process, known as the Shell Coal Gasification Process (SCGP).

\subsubsection{The Shell Coal Gasification Process (SCGP)}

Shell has licensed numerous gasification units worldwide with sizes of 900 to 4000 tonne/day. Coal is pulverized and pressurized in lock-hoppers by means of nitrogen or $\mathrm{CO}_{2}$ and mixed with steam and oxygen before being fed into the gasifier. Typical operating conditions in the gasifier are $1500{ }^{\circ} \mathrm{C}$ under 30 to 40 bar. Due to the high temperature, the ash melts and runs down the reactor walls and is removed as slag. The reactor has a membrane wall containing tubes in which steam is generated. The hot gas exiting the gasifier is first partly cooled to $900^{\circ} \mathrm{C}$ with cold recycle gas of about $280^{\circ} \mathrm{C}$, before entering a syngas cooler, where steam is generated for export as utility. The product gas exits the syngas cooler at about $280^{\circ} \mathrm{C}$ and then passes through a cyclone or filter to remove all solid particles. In the last step, the gas is scrubbed with water to remove mainly hydrogen chloride and ammonia before being passed to downstream units. The SCGP is illustrated in Figure 16: 




Figure 16: The Shell Coal Gasification Process (Higman et al., 2003:131)

\subsubsection{Gasifier coal transport gas}

Coal is transported into the pressurised gasifier via a system of lock hoppers. The design and operation of lock hoppers is not trivial and presents a limitation of between 30 to 40 bar on the maximum gasifier operating pressure for dry-coal feed entrained-flow slagging gasifiers (Higman et al., 2003). Shell gasifiers have been commercially proven up to 32 bar (IEA GHG Report $\mathrm{PH} 4 / 19$, 2003: Section B.7). Nitrogen is most often used as the coal transport gas and is available from the air separation unit that supplies the gasifier with oxygen. The coal loading in order to ensure smooth running coal is about $300 \mathrm{~kg}$ per $\mathrm{m}^{3}$ transport gas. Unfortunately, using nitrogen as transport gas contaminates the product gas and is a drawback when the gasifier is used for syngas production. Although recycled syngas can also be used as coal transport gas, an attractive option is the use of $\mathrm{CO}_{2}$. In the current study, $\mathrm{CO}_{2}$ is available from the downstream gas processing units at little additional costs. Furthermore, it does not contaminate the syngas with extra inerts. Although the effect of $\mathrm{CO}_{2}$ on the syngas cooler duty and overall process efficiency is only slightly different than when nitrogen is used as the coal transport gas, the $\mathrm{H}_{2} / \mathrm{CO}$ ratio of the syngas will decrease marginally, but with no major effect on 
downstream units. The influence of the coal transport gas on the syngas composition is shown in Table A-3 in Appendix A.

\subsubsection{Gasification plant simulation}

A gasifier simulation was developed in Aspen Plus $®$ (2009), making use of the "RYield" reactor simulation block - see Figure 17 for a snapshot of the specification sheet of this model in Aspen Plus ${ }^{\circledR}$ (2009). This model simulates a reactor by specifying the reactor yields of each component. This model is useful when the reaction stoichiometry and kinetics are unknown and when reactor yield distribution data are available. The inerts in the feed are specified and the "RYield"-model normalises the known yields to maintain a mass balance.

For the puposes of this study, it was decided to base the design of the cogeneration plant on the maximum size Shell entrained-flow gasifier available, namely a 4000 tonne/day unit, operating at $1500{ }^{\circ} \mathrm{C}$ and 30 bar. It was assumed that typical South African bituminous coal is the feedstock, as listed in Table A-1. The gasifier yield was based on the yield for a dry coal feed entrained-flow gasifier with South African coal, as reported by Higman et al. (2003) and shown in Table A-2. In order to match the syngas yield of $2070 \mathrm{~m}^{3}{ }_{\mathrm{n}}$ $\left(\mathrm{CO}+\mathrm{H}_{2}\right)$ /tonne moisture and ash free (maf) coal, a loss stream was created in the gasifier simulation. This stream represents unreacted coal from the gasifier due to various process inefficiencies and was calculated as $3.6 \%$ of the gasifier outlet stream.

In the next step, $\mathrm{CO}_{2}$ instead of $\mathrm{N}_{2}$ was introduced into the gasifier as coal transport gas. Note that the yields for $\mathrm{N}_{2}$ as coal transport gas as reported in Table A-3 match the gasifier yield as reported in Table A-2 for the South African case (Refer to " $\mathrm{N}_{2}$ feed @ 30 bar with $99 \% \mathrm{O}_{2}$ feed"). It was assumed that Table A-2 represents a $\mathrm{N}_{2}$ transport gas case. The difference in gasifier yield for a $\mathrm{CO}_{2}$ transport gas could then be read in Table A-3 (refer to Table A3 - see " $\mathrm{CO}_{2}$ feed @ 30 bar with $99 \% \mathrm{O}_{2}$ feed"). The steam and oxygen requirement of the gasifier was calculated using the values in Table A-2. The detail calculations for the gasifier agent (steam and oxygen) requirements, as well as gasifier yields, are shown in Appendix A.

The ash in the coal feed was specified as inert and was removed from the product stream just downstream of the gasifier, simulating the slagging ash stream removed from the bottom of actual gasifiers. The syngas cooler section in the simulation consists of a superheater, a high pressure (HP) as well as a medium pressure (MP) steam generation section. About half of the syngas at $290{ }^{\circ} \mathrm{C}$ (in order to maintain a temperature difference of $20^{\circ} \mathrm{C}$ between hot and cold streams in the MP steam generator) is recycled back to the gasifier to quench the reactor product gas to $900{ }^{\circ} \mathrm{C}$. 
The last step in the gasification unit, is the water scrubbing of the syngas to remove mainly hydrogen chloride and ammonia. In literature (IEA GHG Report $\mathrm{PH} 4 / 19,2003)$, the scrubber outlet temperature is varied between 126 to $160{ }^{\circ} \mathrm{C}$ to maximize the syngas water content, thus limiting the steam flow rate to be added upstream of the water gas shift section. The hot water is added to the syngas stream and flashed at the operating pressure. In practice, this stream needs to be as close as possible to the water saturation temperature at the scrubber pressure in order to maximise water evaporation and minimise exergy losses. In this case, the water saturation temperature at 26 bar is $226^{\circ} \mathrm{C}$, which means the ideal hot water conditions are approximately 27.5 bar, $221^{\circ} \mathrm{C}$. However, for simulation purposes, water at ambient temperature and pressure is used to simplify the thermal efficiency calculations. In addition, deaerated water is to be used to prevent oxygen poisoning of the syngas (Higman et al.,2003: 213) In this simulation, the target $\mathrm{H}_{2} / \mathrm{CO}$ ratio of 2 was reached with scrubber outlet temperature of $144{ }^{\circ} \mathrm{C}$. This eliminated the addition of MP steam before the WGS unit, thanks to additional $\mathrm{H}_{2}$ added from the hydrogen production section. The Aspen Plus ${ }^{\circledR}(2009)$ simulation of the gasification unit is displayed in Figure 18.



Figure 17: Specification of "RYield" reactor model in Aspen Plus $®$ (2009) 


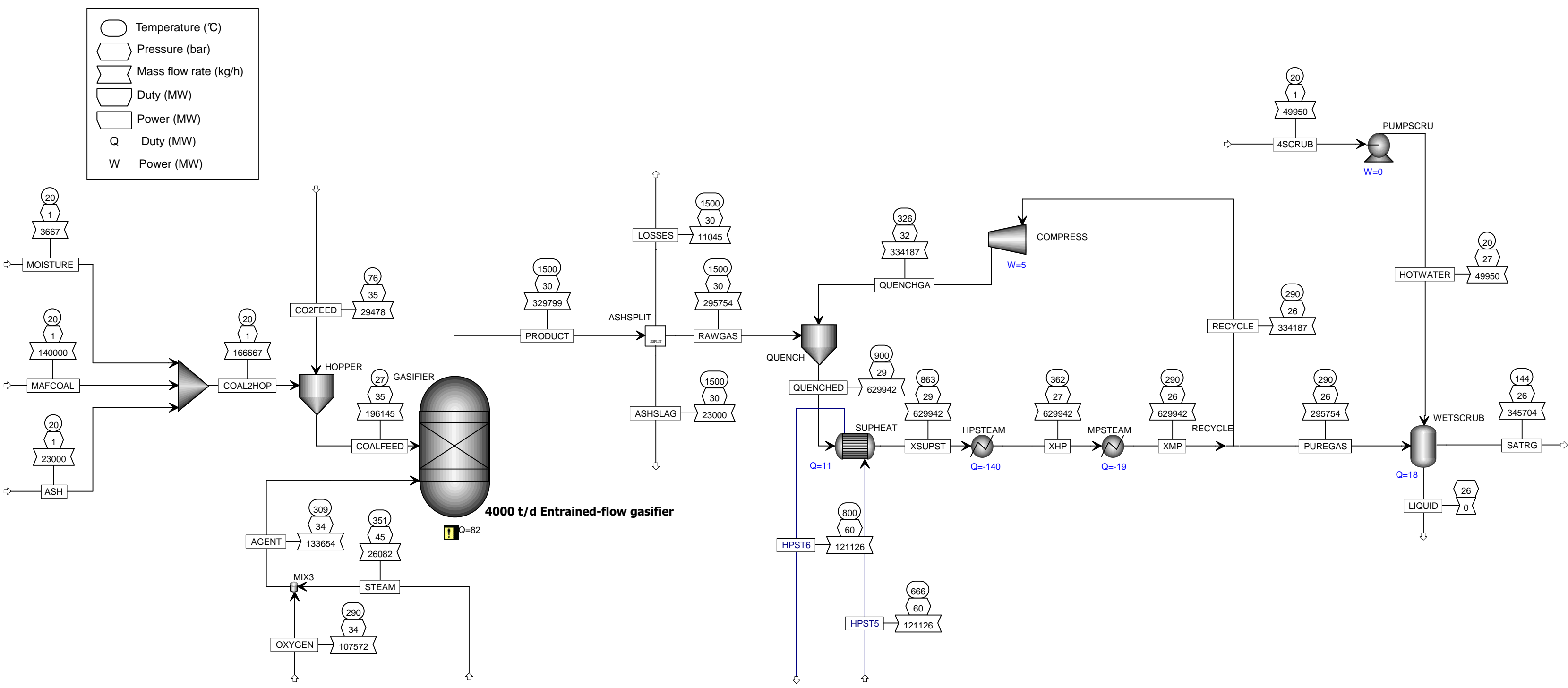

Figure 18: Aspen Plus $\circledast$ (2009) simulation of 4000 tonne/day Shell dry coal feed entrained-flow gasification plant 


\subsection{Water Gas Shift Unit}

The water gas shift (WGS) reaction is important in many chemical processes where the relative amount of $\mathrm{CO}_{2}, \mathrm{CO}$ and $\mathrm{H}_{2}$ are important. These processes include fuel cell applications, as well as adjusting the $\mathrm{H}_{2} / \mathrm{CO}$ ratio of the syngas for the Fischer-Tropsch process (see Figure 10).

\subsubsection{The water gas shift reaction}

The WGS reaction is moderately exothermic and is described by the following equation (Choi et al., 2003):

$$
\mathrm{CO}+\mathrm{H}_{2} \mathrm{O} \leftrightarrow \mathrm{CO}_{2}+\mathrm{H}_{2} \quad \Delta{H^{\circ}}_{298}=-41.1 \mathrm{~kJ} / \mathrm{mol}
$$

In industry, the WGS reaction is carried out in large catalytic reactors under high pressures and temperatures. Numerous studies of the reaction mechanism and kinetics of the WGS reaction have been published during the past few decades. The technology is used in many applications worldwide and is described as an established technology.

\subsubsection{Type of shift converter}

Two of the most common industrial shift conversion processes are the clean shift and sour shift conversion process (IEA GHG Report PH4/19, 2003). The two processes are illustrated in Figure 19 and Figure 20. The clean shift conversion is more complex, but uses inexpensive catalyst, while the sour shift uses a sulphur-tolerant catalyst.

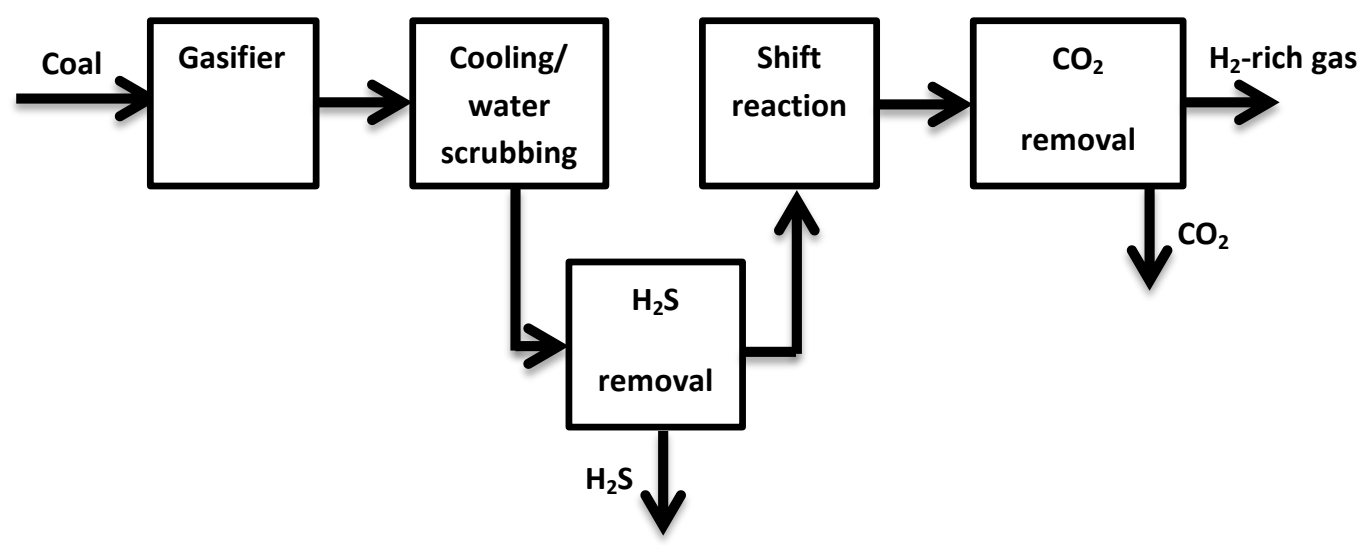

Figure 19: Clean water gas shift conversion (adapted from IEA GHG Report PH4/19, 2003) 


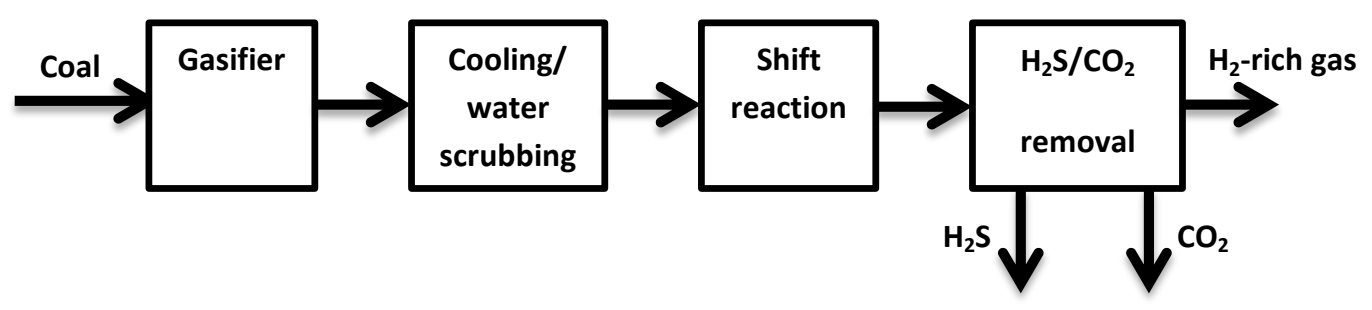

Figure 20: Sour water gas shift process (adapted from IEA GHG Report PH4/19, 2003)

In the IEA GHG study (refer to IEA GHG Report PH4/19, 2003), the authors found the sour shift conversion slightly to be more thermally efficient than the clean shift process. For this reason, a sour shift conversion step, as reported in the IEA GHG study (2003), was used as a benchmark to validate the WGS reactor model.

\subsubsection{Fundamental WGS reactor model}

For the purposes of this study, the specific catalyst and its performance was irrelevant, since a catalyst only influences the rate of a chemical reaction and not its equilibrium. It was assumed that the catalytic WGS reactor could achieve the maximum possible or equilibrium conversion of $\mathrm{CO}$ into $\mathrm{CO}_{2}$, although industrial processes may require an additional WGS shift step to reach the desired $\mathrm{CO}$ conversion. The reactor and catalyst design was therefore outside the scope of this study.

The WGS reactor can be approximated with a nonisothermal adiabatic reactor model. This model takes heat effects into account when solving reactor design problems, which means that the equilibrium conversion of an exothermic reaction decreases with increasing temperature. The details of this approach is well documented in literature (Fogler, 2006) and will not be repeated in this text. A detailed derivation of the WGS reactor model and assumptions, including sample calculations, are presented in Appendix B. The following method was used to develop the reactor model:

1) Mass Balance: Use rate law and stoichiometry to write equilibrium conversion $\left(X_{e}\right)$ in terms of equilibrium constant $\left(K_{e q}\right)$ :

As reported by Choi et al., (2003), the equilibrium constant of the WGS reaction can be derived in a conventional way from thermodynamic properties as a function of temperature as shown in equation (2) below. The equilibrium constant is plotted as a function of temperature in Figure 21.

$$
\begin{gathered}
\ln \left(K_{e q}\right)=\frac{5693.5}{T}+1.077 \ln T+5.44 \times 10^{-4} T-1.125 \times 10^{-7} T^{2} \\
-\frac{49170}{T^{2}}-13.148
\end{gathered}
$$


where $K_{e q} \cong \frac{P_{\mathrm{CO}_{2} \cdot P_{\mathrm{H}_{2}}}}{P_{\mathrm{H}_{2} \mathrm{O} \cdot P_{\mathrm{CO}}}}$

2) Energy balance: Determine the relationship between temperature and equilibrium conversion $\left(X_{E B}\right)$ from the energy balance:

Assume zero work $(W=0)$ and adiabatic operation $(Q=0)$. The energy balance then reduces to:

$X_{E B}=\frac{\sum \Theta_{i} c_{p_{i}}\left(T-T_{i 0}\right)}{-\left[\Delta H^{\circ}{ }_{R x}\left(T_{R e f}\right)+\Delta c_{p}\left(T-T_{R e f}\right)\right]}$

3) Determine maximum conversion achieved at the intersection of equilibrium conversion as function of temperature $\left(X_{e}\right)$ with conversion-temperature relationship $\left(X_{E B}\right)$, as illustrated in Figure 21:

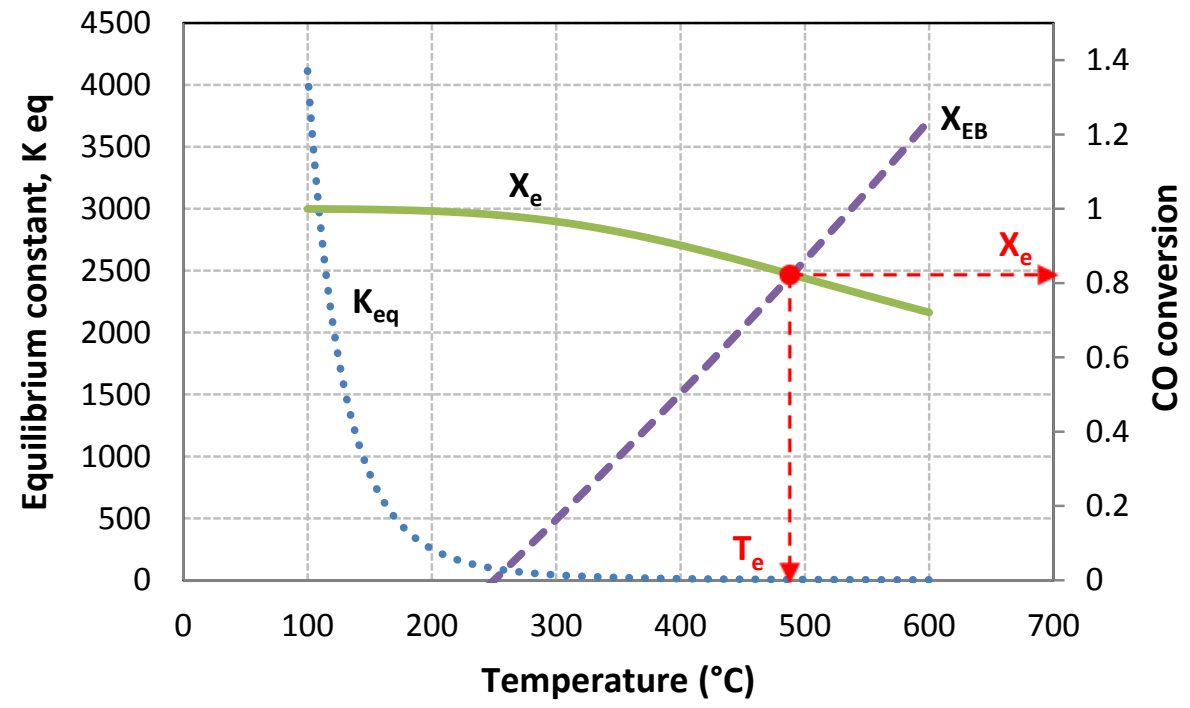

Figure 21: Illustration of the procedure to determine the equilibrium conversion and temperature for a nonisothermal, adiabatic WGS reactor model

\subsubsection{Validation of WGS reactor model in Aspen Plus $®$ (2009)}

In theory the Aspen Plus ${ }^{\circledR}$ (2009) "RGibbs" reactor model would be able to model the WGS reaction accurately. This model minimises the Gibbs free energy function of all species in the reactor when a system reaches equilibrium at constant pressure. In order to verify the accuracy of this model, it was compared to the fundamental reactor model, which was developed as explained above. An illustration of the Aspen Plus ${ }^{\circledR}$ (2009) "RGibbs" model is shown in Figure 22. The feeds to both models were exactly the same and 
consisted of a mixture of steam, $\mathrm{CO}_{2}, \mathrm{CO}, \mathrm{H}_{2}$ and inert $\mathrm{N}_{2}$. The feed composition is shown in Table 7 and the results in Table 8.

The Aspen Plus $®$ (2009) "RGibbs" model were configured as follows:

- All components were considered as possible products, but $\mathrm{N}_{2}$ specified as inert, otherwise the exothermic hydrogenation of $\mathrm{N}_{2}$ to $\mathrm{NH}_{3}$ will cause slightly too high temperatures compared to the fundamental WGS reactor model. This implies that the WGS catalyst primarily facilitates the WGS reaction and the extent of the nitrogen hydrogenation reaction was therefore assumed to be negligible.

- Model specified with zero heat duty to simulate adiabatic reactor

- Pressure $=101.325 \mathrm{kPa}$ (1 atmosphere)

- Phase and chemical equilibrium to be calculated

Table 7: Feed composition to WGS reactor model used in the validation of the Aspen Plus ${ }^{\circledR}(2009)$ model

\begin{tabular}{|l|r|}
\hline \multicolumn{2}{|c|}{ Feed composition } \\
\hline $\mathrm{H}_{2} \mathrm{O} / \mathrm{CO}$ feed ratio, $\Theta \mathrm{H}_{2} \mathrm{O}=\mathrm{F}_{2} \mathrm{O}_{0} / \mathrm{FCO}_{0}$ & 2 \\
\hline $\mathrm{CO}_{2} / \mathrm{CO}$ feed ratio, $\Theta \mathrm{CO}_{2}=\mathrm{FCO}_{20} / \mathrm{FCO}_{0}$ & 0.067 \\
\hline $\mathrm{H}_{2} / \mathrm{CO}$ feed ratio, $\Theta_{\mathrm{H}_{2}}=\mathrm{FH}_{20} / \mathrm{FCO}_{0}$ & 0.5 \\
\hline $\mathrm{N}_{2} / \mathrm{CO}$ feed ratio, $\Theta_{2}=\mathrm{FN}_{20} / \mathrm{FCO}_{0}$ & 0.1 \\
\hline $\mathrm{T}_{0}$, feed temperature & $250 \quad{ }^{\circ} \mathrm{C}$ \\
\hline$\Delta \mathrm{H}_{\mathrm{RX}}^{\circ}(298 \mathrm{~K})$ & $-41100 \mathrm{~kJ} / \mathrm{kmol}$ \\
\hline
\end{tabular}

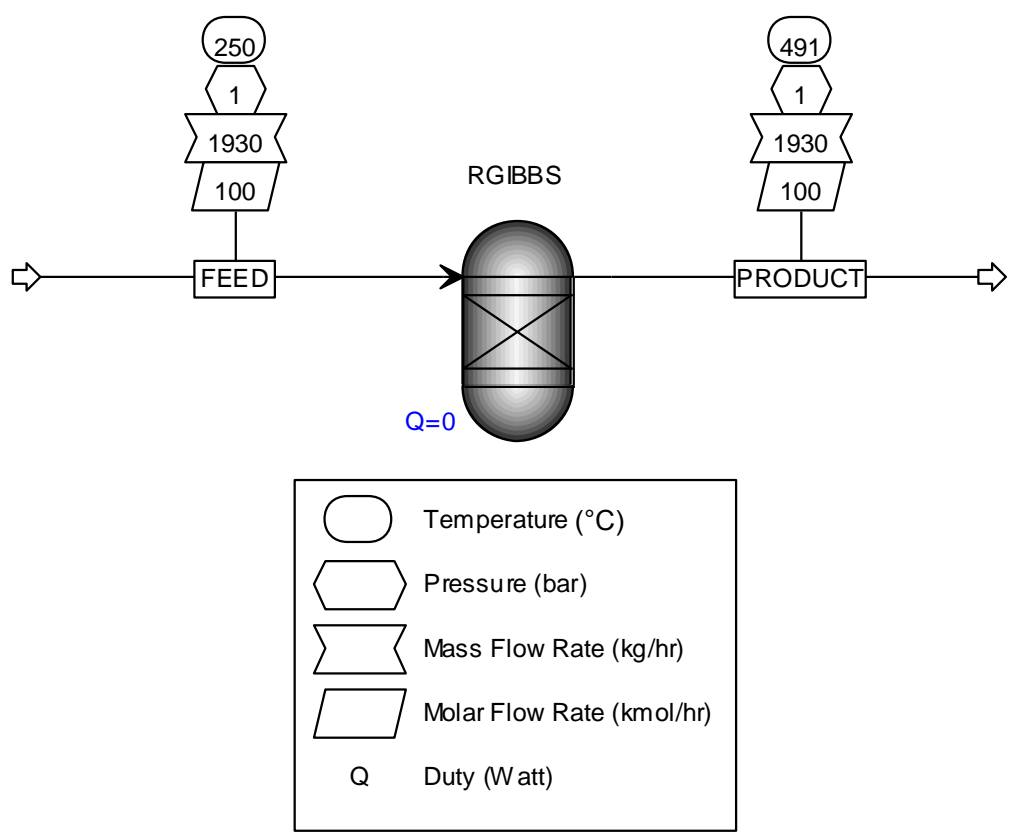

Figure 22: Aspen Plus ${ }^{\circledR}$ (2009) model of a WGS reactor 
Table 8: Results of Aspen Plus $®$ (2009) model validation

\begin{tabular}{|l|c|c|}
\hline \multicolumn{1}{|c|}{ Output } & $\begin{array}{c}\text { Fundamental } \\
\text { model }\end{array}$ & $\begin{array}{c}\text { Aspen Plus } \mathbb{8} \\
\mathbf{( 2 0 0 9 )} \text { RGibbs } \\
\text { model }\end{array}$ \\
\hline Equilibrium conversion, $\mathrm{X}_{\mathrm{e}}$ calculated & 0.82 & 0.82 \\
\hline Equilibrium temperature, $\mathrm{T}_{\mathrm{e}}$ calculated & $490^{\circ} \mathrm{C}$ & $491^{\circ} \mathrm{C}$ \\
\hline
\end{tabular}

The results of the fundamental model calculation is shown in Figure 21 (refer to Appendix B for more detailed sample calculations of this example). This result was compared to the Aspen Plus ${ }^{\circledR}(2009)$ "RGibbs" model in Table 8, which undoubtedly confirms the accuracy of using the "RGibbs" reactor model in Aspen Plus ${ }^{\circledR}$ (2009) to model the WGS catalytic reactor. In the next step, the model was compared with literature values to further verify the accuracy of this approach to model industrial WGS catalytic reactors.

\subsubsection{Comparison of fundamental WGS reactor model with literature results}

The fundamental WGS reactor model developed in section 3.3.3, was compared to industrial WGS reactor designs, as reported in the IEA GHG study (refer to IEA GHG Report PH4/19, 2003: Case B1 \& D1). As can be seen in Table 9, the fundamental model matches the literature values quite well, although the the industrial design is about $20 \%$ lower than the theoretical equilibrium conversion of $\mathrm{CO}$ (from fundamental model calculations). The reason for this phenomenon is that the fundamental model calculates the equilibrium conversion of $\mathrm{CO}$, which is the highest possible conversion of $\mathrm{CO}$. Industrial reactors, however, will have a lower $\mathrm{CO}$ conversion due to the reactor design, catalyst loading, catalyst deactivation, mass transfer effects, etc. Choi et al. (2003) found that experimental values of $\mathrm{CO}$ conversion were $70 \%$, while the calculated values were $87 \%$; a difference of $20 \%$, which confirms this phenomenon.

Note that the IEA GHG study used operating pressures of about 32 bar, while the fundamental model assumed a pressure of 1 bar. The pressure at which the WGS reaction takes place, will have a slight influence on the equilibrium temperature due to higher heat capacities of species (especially $\mathrm{H}_{2} \mathrm{O}$ vapour) at higher pressure. The effect of pressure on the heat capacities of species in the WGS reaction is shown in Figure 23. This figure shows that the heat capacity of $\mathrm{H}_{2} \mathrm{O}$ increases from about $36 \mathrm{~kJ} / \mathrm{kmol} . \mathrm{K}$ at 1 bar to about 46 $\mathrm{kJ} / \mathrm{kmol} . \mathrm{K}$ at 30 bar, while the heat capacity of all the other gasses are virtually constant irrespective of pressure. However, it was found that the effect of pressure on the fundamental model results was negligible and it was therefore concluded that the fundamental WGS model correlated well with literature values. This also implied that the Aspen Plus ${ }^{\circledR}$ (2009) "RGibbs" 
reactor model can be used to accurately model the expected equilibrium $\mathrm{CO}$ conversion and equilibrium temperature of an industrial WGS catalytic reactor.

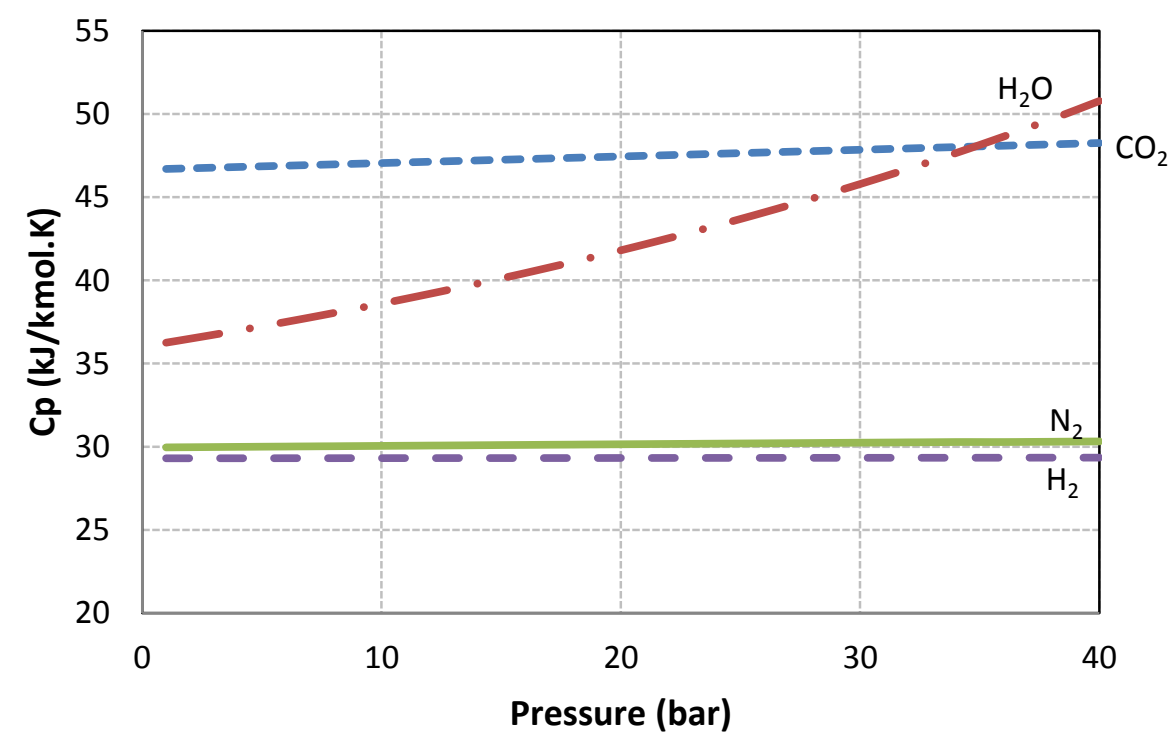

Figure 23: Effect of pressure on the heat capacities of species in WGS reaction at a temperature of $300{ }^{\circ} \mathrm{C}$

Table 9: Comparison of fundamental WGS model with literature values

\begin{tabular}{|c|c|c|c|}
\hline FEED COMPOSITION & \begin{tabular}{|c|} 
CaseB1 \\
Shift reactor 1
\end{tabular} & $\begin{array}{c}\text { CaseB1 } \\
\text { Shift reactor } 2\end{array}$ & Case D1 \\
\hline $\begin{array}{l}\mathrm{H}_{2} \mathrm{O} / \mathrm{CO} \text { feed ratio, } \\
\Theta_{\mathrm{H}_{2} \mathrm{O}}=\mathrm{FH}_{2} \mathrm{O}_{0} / \mathrm{FCO}_{0}\end{array}$ & 2 & 4 & 3.9 \\
\hline $\begin{array}{l}\mathrm{CO}_{2} / \mathrm{CO} \text { feed ratio, } \\
\mathrm{\Theta CO}_{2}=\mathrm{FCO}_{20} / \mathrm{FCO}_{0}\end{array}$ & 0.025 & 2.1 & 0.47 \\
\hline $\begin{array}{l}\mathrm{H}_{2} / \mathrm{CO} \text { feed ratio, } \\
\Theta \mathrm{H}_{2}=\mathrm{FH}_{20} / \mathrm{FCO}_{0}\end{array}$ & 0.53 & 3.6 & 0.97 \\
\hline $\begin{array}{l}\mathrm{N}_{2} / \mathrm{CO} \text { feed ratio, } \\
\Theta_{\mathrm{N}_{2}}=\mathrm{FN}_{20} / \mathrm{FCO}_{0}\end{array}$ & 0.08 & 0.24 & 0.023 \\
\hline $\begin{array}{l}T_{0} \text {, feed temperature } \\
\text { (estimated to match } T_{e} \text { from } \\
\text { literature) }\end{array}$ & 225 & 250 & 267.8 \\
\hline \multicolumn{4}{|c|}{ OUTPUT (literature value is displayed in brackets) } \\
\hline $\mathrm{X}_{\mathrm{e}}$ calculated (literature) & $0.84(0.67)$ & $0.85(0.8)$ & $0.905(0.9)$ \\
\hline $\mathrm{T}_{\mathrm{e}}$ calculated (literature) ${ }^{\circ} \mathrm{C}$ & $474(451)$ & $334(331)$ & $434(434)$ \\
\hline
\end{tabular}


The WGS unit was modelled in Aspen Plus $®$ (2009) by means of a "RGibbs" reactor model, as illustrated in Figure 24. The saturated raw gas is first preheated to $250{ }^{\circ} \mathrm{C}$, in accordance with the IEA GHG study (refer to IEA GHG Report PH4/19, 2003: Case B1). The last step in the gasification unit, before the raw gas is sent to the WGS reactor, is the water scrubbing of the syngas to remove mainly hydrogen chloride and ammonia. The hot water is added to the syngas stream and flashed at the operating pressure. Note that MP steam is added to the WGS reactor feed in Case B1 in order to reach the required CO conversion in the WGS reactor. In the IEA GHG Report, the scrubber outlet temperature is varied between 126 and $160{ }^{\circ} \mathrm{C}$ "in order to maximize the syngas water content, thus limiting the steam flow rate to be added upstream of the sour shift section". In this simulation however, the target $\mathrm{H}_{2} / \mathrm{CO}$ ratio of 2 is reached with scrubber water outlet temperature at $144{ }^{\circ} \mathrm{C}$ and consequently no MP steam is needed, due to additional $\mathrm{H}_{2}$ added from the electrolysis unit.

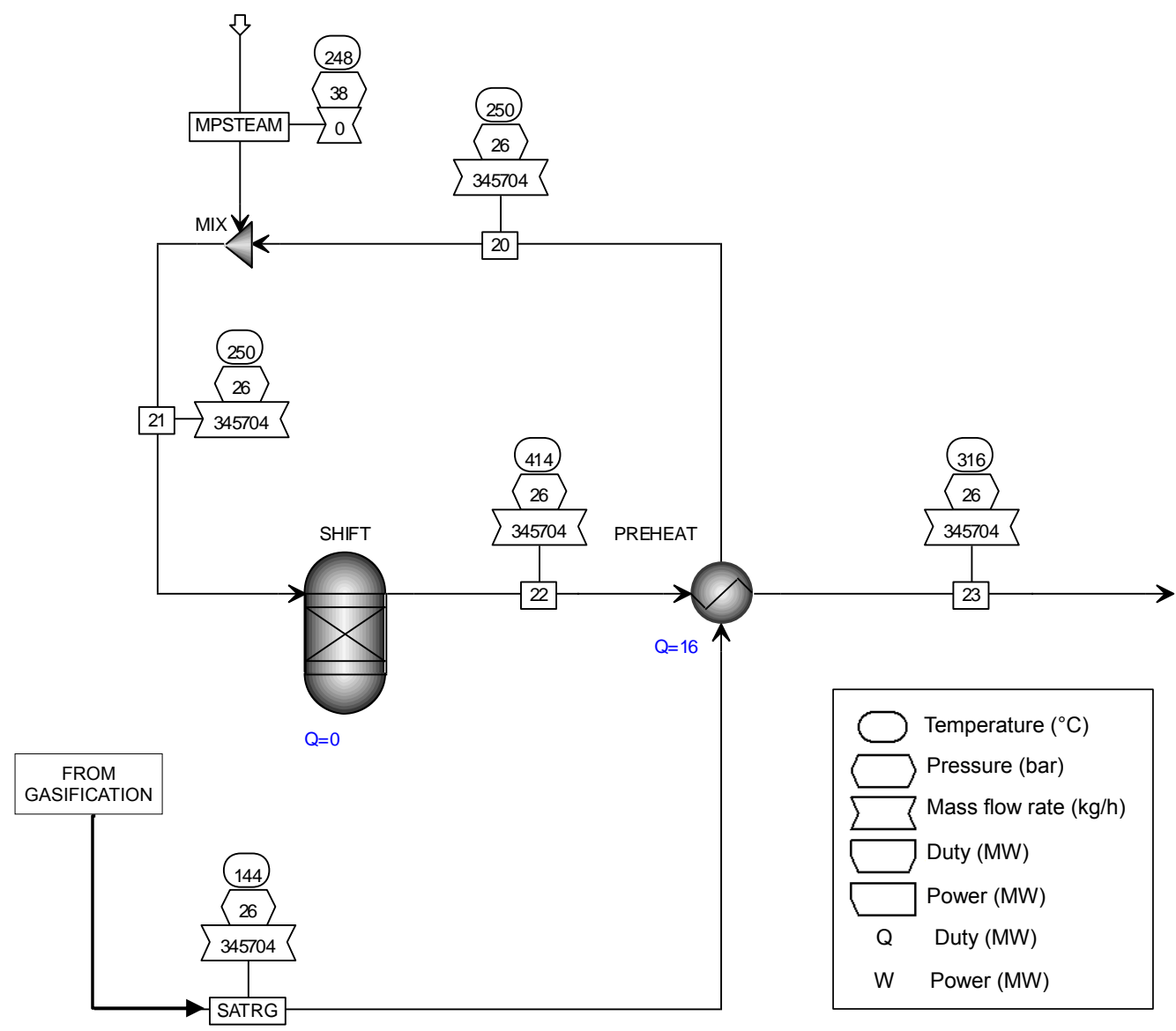

Figure 24: Aspen Plus $₫$ (2009) simulation model of WGS unit 
Ideally, the hot water stream to the scrubber needs to be as close as possible to the water saturation temperature at the scrubber pressure in order to maximise water evaporation and minimise exergy losses. In this case, the saturation temperature at 26 bar is $226{ }^{\circ} \mathrm{C}$, which means that the ideal hot water conditions are around 27.5 bar and $221{ }^{\circ} \mathrm{C}$. However, to simplify the thermal efficiency calculations, water at ambient temperature and pressure was used. This implies that practical WGS reactors might need additional steam, depending on the efficiency of water evaporation in the scrubber and the required $\mathrm{H}_{2} / \mathrm{CO}$ ratio in the product gas. Although small, the additional MP steam to the WGS reactor will reduce the thermal efficiency of a practical plant slightly, compared to this simulation results. 


\subsection{High Temperature Electrolysis Unit}

\subsubsection{Hydrogen production plant technology selection}

As explained previously, water is a more sustainable source of hydrogen, since no $\mathrm{CO}_{2}$ is emitted in the process. However, water splitting is a more expensive route to hydrogen production than coal gasification in the absence of cost penalties for the associated carbon emissions (Elder and Allen, 2009:503). The most promising $\mathrm{CO}_{2}$ free processes for hydrogen production are the Sulphur lodine ( $\mathrm{SI}$ ) and Hybrid Sulphur (HyS) thermochemical cycles, as well as high temperature electrolysis (HTE) (Refer to section 2 for a brief explanation of these processes).

Numerous different process flow schemes for coupling a high temperature nuclear reactor to a hydrogen production plant have been proposed and evaluated. Some examples of these electricity and hydrogen cogeneration plants are illustrated in Figure 9 and Figure 25. A comparison of the thermal to hydrogen efficiency of the HTE, HyS and SI processes is shown in Table 10.

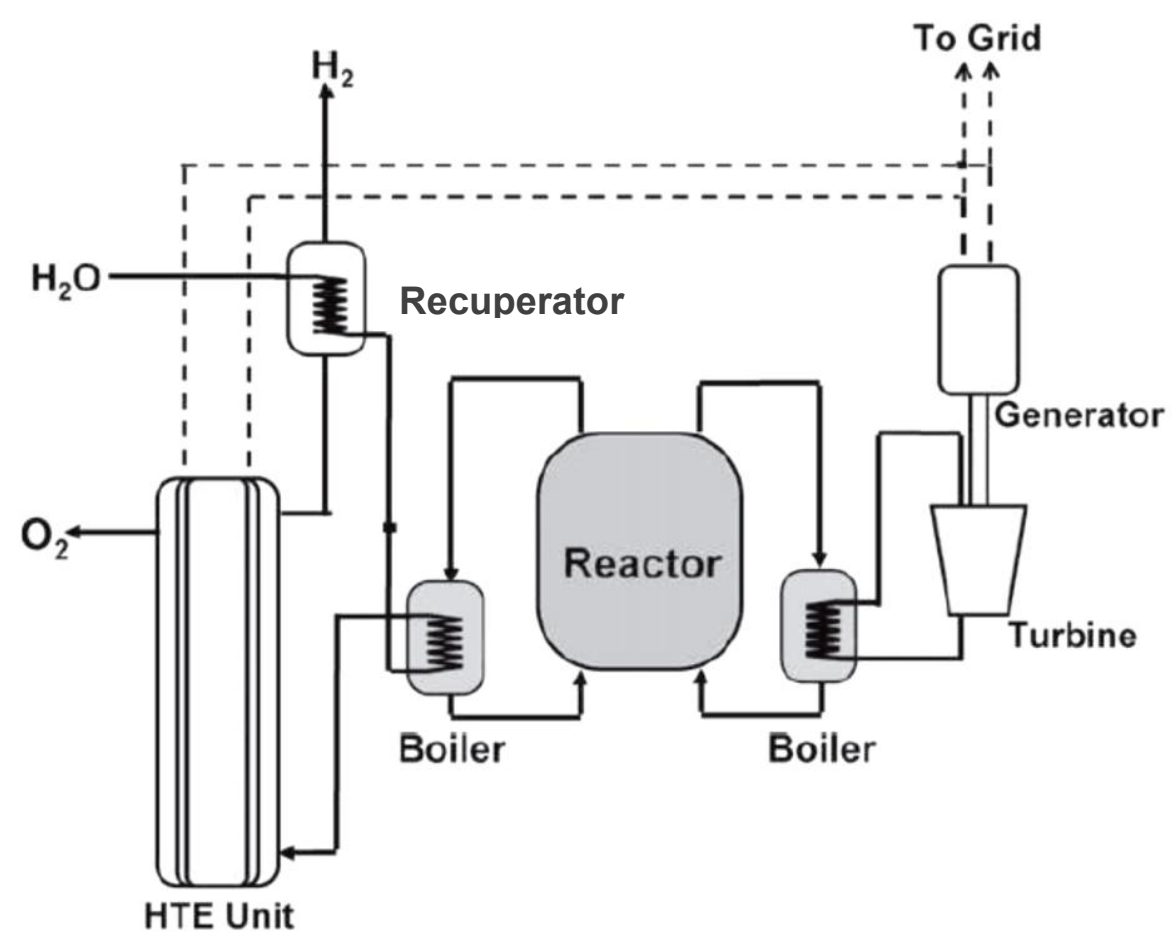

Figure 25: Conceptual design of a HTE cogeneration plant (Adapted from Fujiwara et al., 2008) 
Table 10: Comparison of hydrogen production thermal to hydrogen efficiencies (adapted from Yildiz and Kazimi, 2006)

\begin{tabular}{|l|l|c|c|c|c|}
\hline Process & Nuclear reactor & \multicolumn{3}{|l|}{ Operating range } \\
\cline { 3 - 6 } & & Minimum & \multicolumn{2}{l|}{ Maximum } \\
\cline { 3 - 6 } & & Temp $\left({ }^{\circ} \mathrm{C}\right)$ & Efficiency & Temp $\left({ }^{\circ} \mathrm{C}\right)$ & Efficiency \\
\hline HTE & Modular $\mathrm{He}+$ gas turbine & 850 & 0.50 & 950 & 0.53 \\
\hline $\mathrm{HyS}$ & Modular He & 800 & 0.53 & 900 & 0.57 \\
\hline $\mathrm{SI}$ & Modular He & 800 & 0.38 & 900 & 0.52 \\
\hline
\end{tabular}

The most studied thermochemical process for nuclear hydrogen production, the $\mathrm{SI}$ process, requires heat addition at a temperature of approximately $900{ }^{\circ} \mathrm{C}$. Challenges for this technology include corrosion, membrane separations and catalyst degradation. O'Brien (2008) reports detailed process evaluations that have been performed at the Idaho National Laboratory (INL) to compare different electrolysis-based hydrogen production technologies coupled to advanced nuclear reactors. The results of this study are presented in Figure 26. The figure shows the hydrogen production efficiency (based on the high heating value or $\mathrm{HHV}$ ) plotted against the reactor outlet temperature.

Three different advanced-reactor/power-conversion combinations were compared: a helium-cooled reactor coupled to a direct recuperative Brayton cycle, a sodium-cooled fast reactor coupled to a Rankine cycle, and a supercritical $\mathrm{CO}_{2}$-cooled reactor coupled to a direct recompression cycle. In all cases, both HTE and low temperature electrolysis (LTE) were used for hydrogen production. A curve that represents $65 \%$ of the maximum theoretical thermodynamic efficiency of hydrogen production, as well as the efficiency curve for the $\mathrm{SI}$ thermochemical process (as developed by General Atomics) is also included in this figure. Although the efficiency of the SIprocess is higher than $50 \%$ for operating temperatures of $900{ }^{\circ} \mathrm{C}$, its efficiency falls quickly with decreasing temperature and drops below LTE coupled to HTR's for reactor outlet temperatures below $800{ }^{\circ} \mathrm{C}$. 




Figure 26: Thermal to hydrogen efficiencies for electrolysis technologies coupled to advanced nuclear reactors (O'Brien, 2008)

Note that the SI and High Temperature Electrolysis (HTE) process has similar thermal to hydrogen efficiencies at reactor outlet temperatures above $900{ }^{\circ} \mathrm{C}$. The HTE process use electricity as primary energy input and the electricity and hydrogen production ratios can be adjusted to the client's needs (Fujawara et al., 2008). O'Brien (2008) commented that current planning indicate that HTR reactor outlet temperatures will be at $900{ }^{\circ} \mathrm{C}$ or lower, which favours HTE. According to O'Brien (2008), the HTE process has fewer technical challenges to large-scale implementation. HTE was therefore the preferred technology for hydrogen production in this study. Refer to Table 4 for the major HTR consortiums preferred hydrogen production technology.

\subsubsection{Thermodynamics of high temperature electrolysis}

Consider the control volume around an isothermal water splitting process at constant pressure as shown in Figure 27, and applying the first law:

but for reversible operation,

$$
Q+W=\Delta H_{R}
$$

$$
\begin{gathered}
Q_{\text {rev }}=T \Delta S_{R} \\
\therefore W_{\text {rev }}=\Delta H_{R}-T \Delta S_{R}=\Delta G_{R}
\end{gathered}
$$

The quantities in equation $3-6$ are plotted as a function of temperature in Figure 28: 


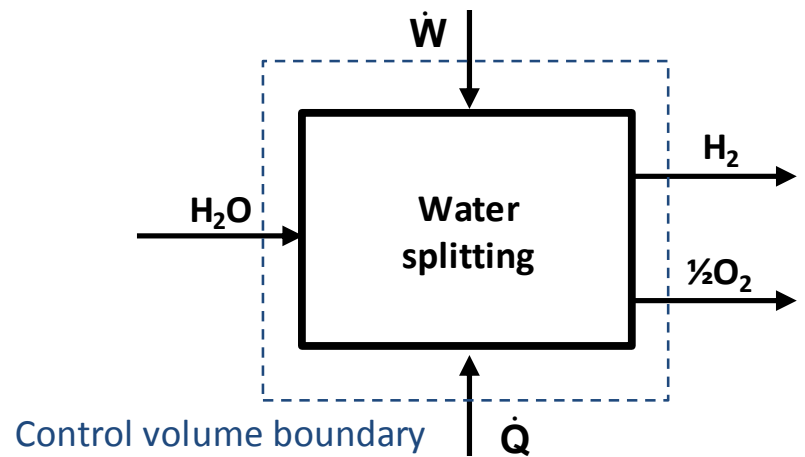

Figure 27: Energy balance for the water splitting process

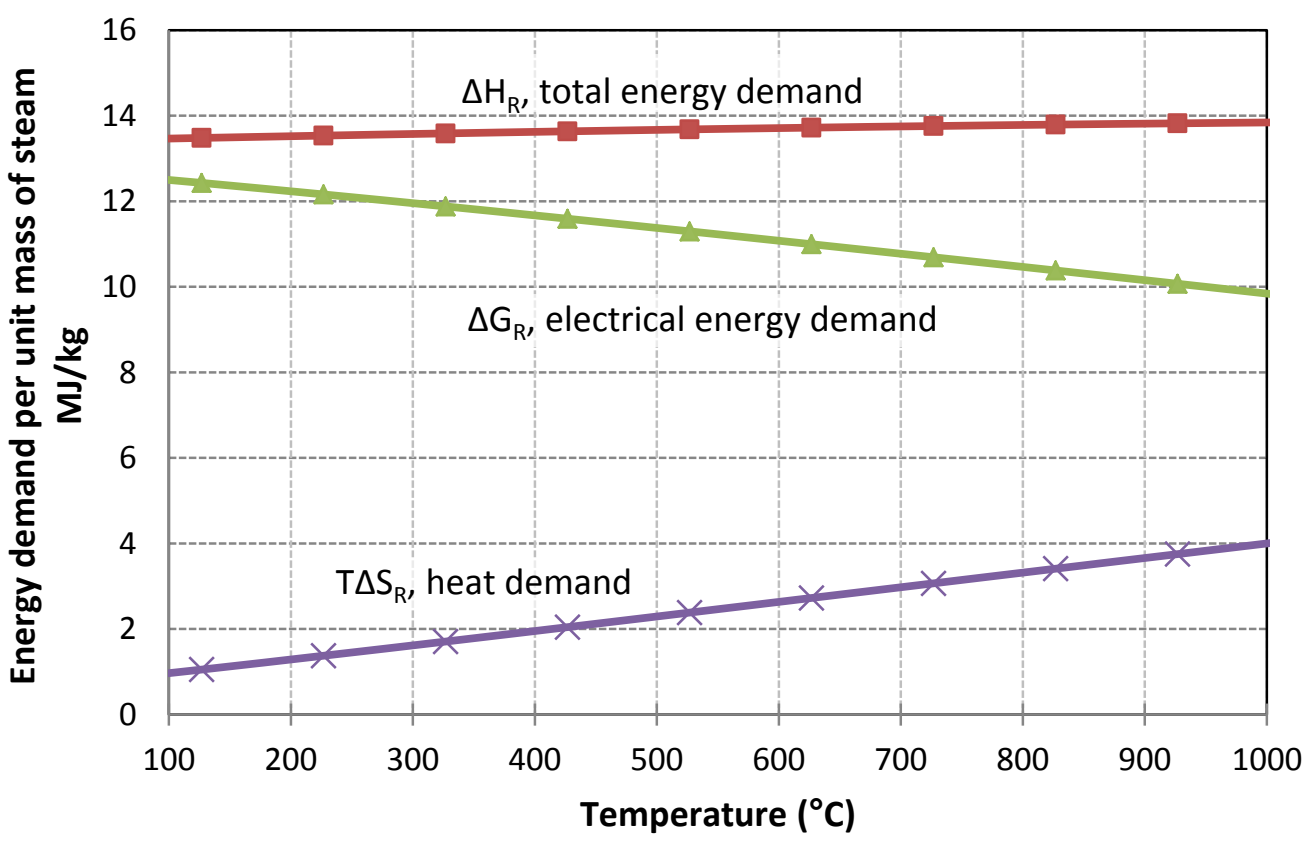

Figure 28: Energy requirements for water splitting at 1 bar (NIST data, [S.a])

Figure 28 shows how the Gibbs free energy or electrical energy demand for the water splitting process decreases with increasing temperature, while the process heat demand or $\mathrm{T} \Delta \mathrm{S}_{\mathrm{R}}$ increases at higher temperatures. This implies that more energy in the form of heat can be supplied at higher temperatures. At the same time, the electrical work requirement, which can only be produced at thermal efficiencies of less than $50 \%$, decreases at higher temperatures, resulting in higher overall thermal to hydrogen efficiencies at high temperatures. According to O'Brien (2008), the ratio of $\Delta \mathrm{G}_{\mathrm{R}}$ to $\Delta \mathrm{H}_{\mathrm{R}}$ is $93 \%$ at $100{ }^{\circ} \mathrm{C}$, while this ratio decreases to $70 \%$ at $1000{ }^{\circ} \mathrm{C}$.

\subsubsection{Ideal thermal to hydrogen efficiency for water splitting}

In the case where the heat addition to the power cycle temperature $T_{H, P}$ is not equal to the heat addition temperature to the electrolyser $\mathrm{T}_{\mathrm{H}, \mathrm{e}}$, the system can 
be illustrated by Figure 29 The calculation of the ideal thermal to hydrogen efficiency of the process is shown below (O'Brien, 2008):

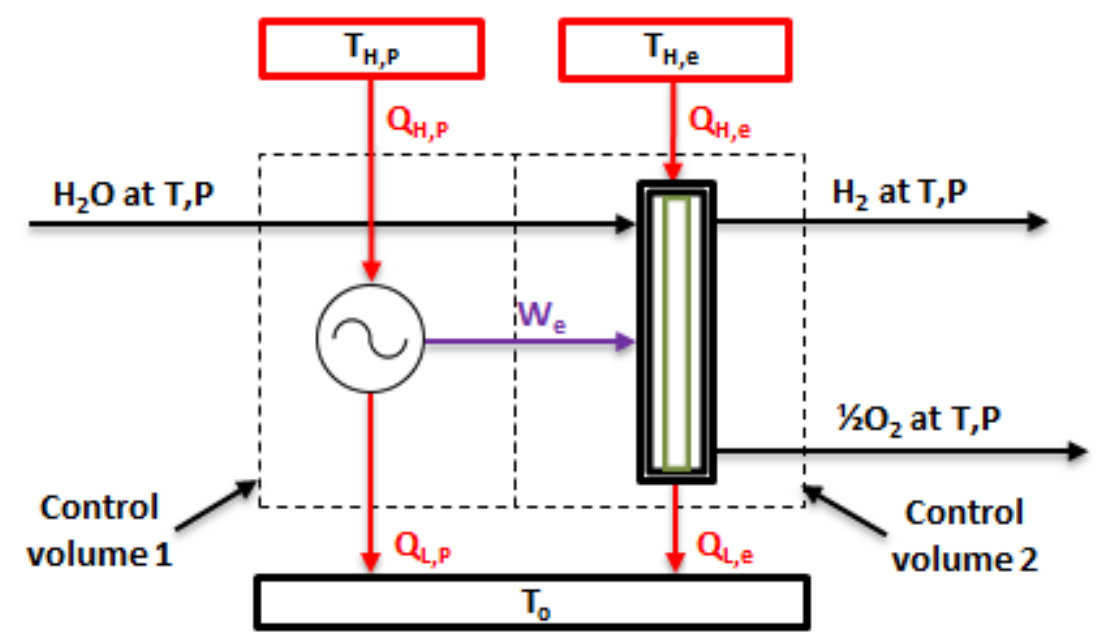

Figure 29: Illustration of a water splitting process with different heat addition temperatures for the power cycle and the electrolyser (O'Brien, 2008)

The thermal to hydrogen efficiency of the system is defined as

$$
\eta_{H}=\frac{\Delta H_{R}}{Q_{t o t}}=\frac{\Delta H_{R}}{Q_{H, P}+Q_{H, e}}
$$

For the ideal case,

$$
\begin{gathered}
Q_{H, P}=\frac{W_{n e t}}{\eta_{t h}}=\frac{\Delta H_{R}}{\eta_{t h} \eta_{e}} \\
Q_{H, e}=T_{H, e} \Delta S_{R}\left(T_{H, e}\right) \\
\eta_{H}=\frac{\Delta H_{R}}{\frac{\Delta H_{R}}{\eta_{t h} \eta_{e}}+T_{H, e} \Delta S_{R}\left(T_{H, e}\right)}
\end{gathered}
$$

According to the Carnot principle, the maximum possible thermal efficiency for the power cycle is

$$
\eta_{t h, P, \max }=1-\frac{T_{L}}{T_{H, P}}
$$

and the maximum electrolysis efficiency:

$$
\eta_{e, \max }=\frac{H H V}{H H V-\Delta S_{R}\left(T_{H, e}\right) \cdot\left(T_{H, e}-T_{L}\right)-T_{L} \Delta S_{R}\left(T_{L}\right)}
$$




\subsubsection{Water splitting model}

In order to develop a generic model for a practical water splitting process, the following method was followed:

- Properties (enthalpy and entropy) of pure species were evaluated with Aspen Plus ${ }^{\circledR}(2009)$ over temperature range from $0{ }^{\circ} \mathrm{C}$ to $1000{ }^{\circ} \mathrm{C}$ at pressure of 29 bar gauge.

- $\mathrm{H}_{2} \mathrm{O}$ assumed to be liquid at temperatures below $100{ }^{\circ} \mathrm{C}$ and vapour at temperatures higher than $100^{\circ} \mathrm{C}$.

- These values were verified with NIST thermochemical tables (NIST data, [S.a])

- Change in enthalpy and entropy were calculated for electrolysis reaction

- $\Delta \mathrm{S}_{\mathrm{R}}\left(\mathrm{T}_{\mathrm{H}}\right)=\mathrm{S}\left(\mathrm{H}_{2}\right)+0,5 \times \mathrm{S}\left(\mathrm{O}_{2}\right)-\mathrm{S}\left(\mathrm{H}_{2} \mathrm{O}\right)$ with all species at $T_{H}$

- $\Delta \mathrm{H}_{\mathrm{R}}\left(\mathrm{T}_{\mathrm{H}}\right)=\mathrm{H}\left(\mathrm{H}_{2}\right)+0,5 \times \mathrm{H}\left(\mathrm{O}_{2}\right)-\mathrm{H}\left(\mathrm{H}_{2} \mathrm{O}\right)$ with all species at $T_{H}$

- Use calculated values in equation 3-10 and 3-12, but with $\Delta \mathrm{H}_{\mathrm{R}}$ instead of the higher heating value (HHV) for $\mathrm{H}_{2}$ in equation 3-12.

The maximum electrolysis efficiency as calculated with equation $3-12$, is shown in Figure 30:

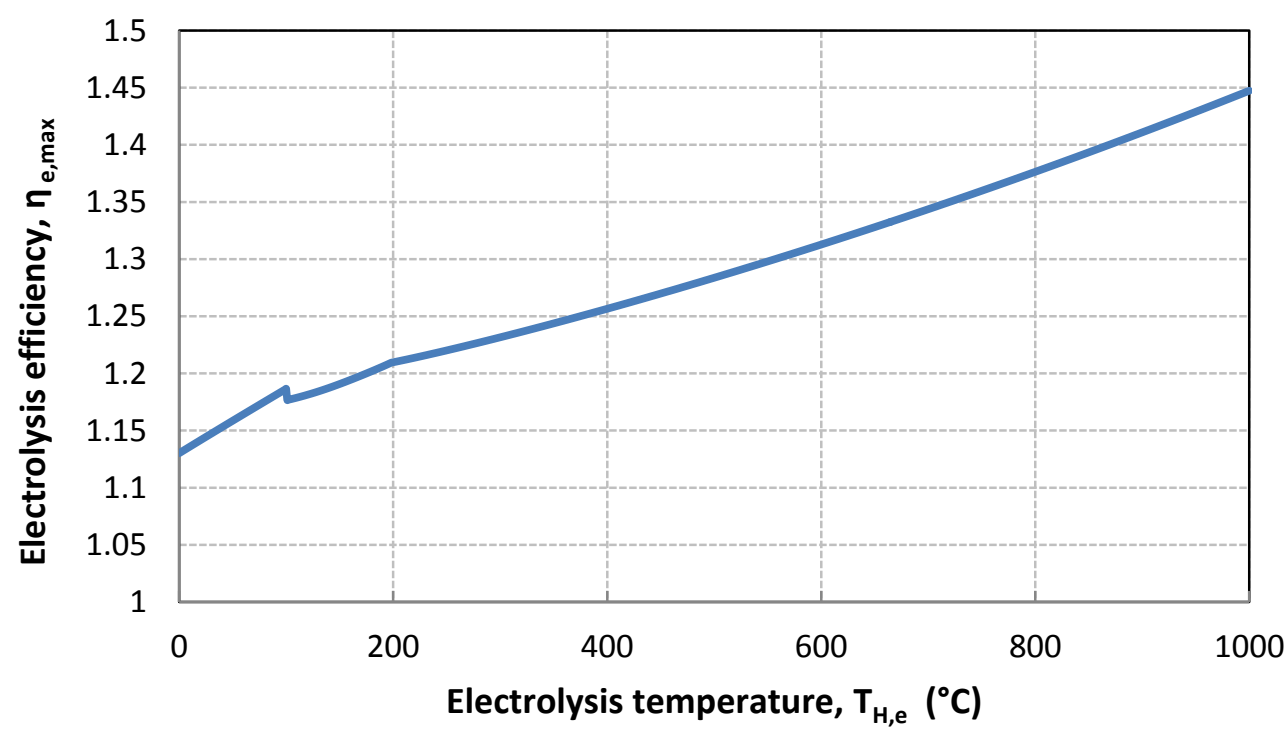

Figure 30: Maximum possible electrolysis efficiency as function of temperature $\mathbf{T}_{\mathrm{H}, \mathrm{e}}$

This calculated maximum electrolysis efficiency (as shown in in Figure 30) was used as input for equation 3-10 to calculate the ideal thermal to hydrogen efficiency for a water splitting process with different heat addition temperatures for the power cycle and the electrolyser. The result is plotted in Figure 31, together with the calculated thermal to hydrogen efficiency for a water splitting process with the same heat addition temperatures for the power cycle and the electrolyser (O'Brien, 2008). These water splitting model results compare well 
with the values reported in literature (O'Brien, 2008:10). It illustrates that the potential thermal to hydrogen efficiency gains from HTE are modest if the power cycle heat addition temperature (and therefore thermal efficiency) is fixed.

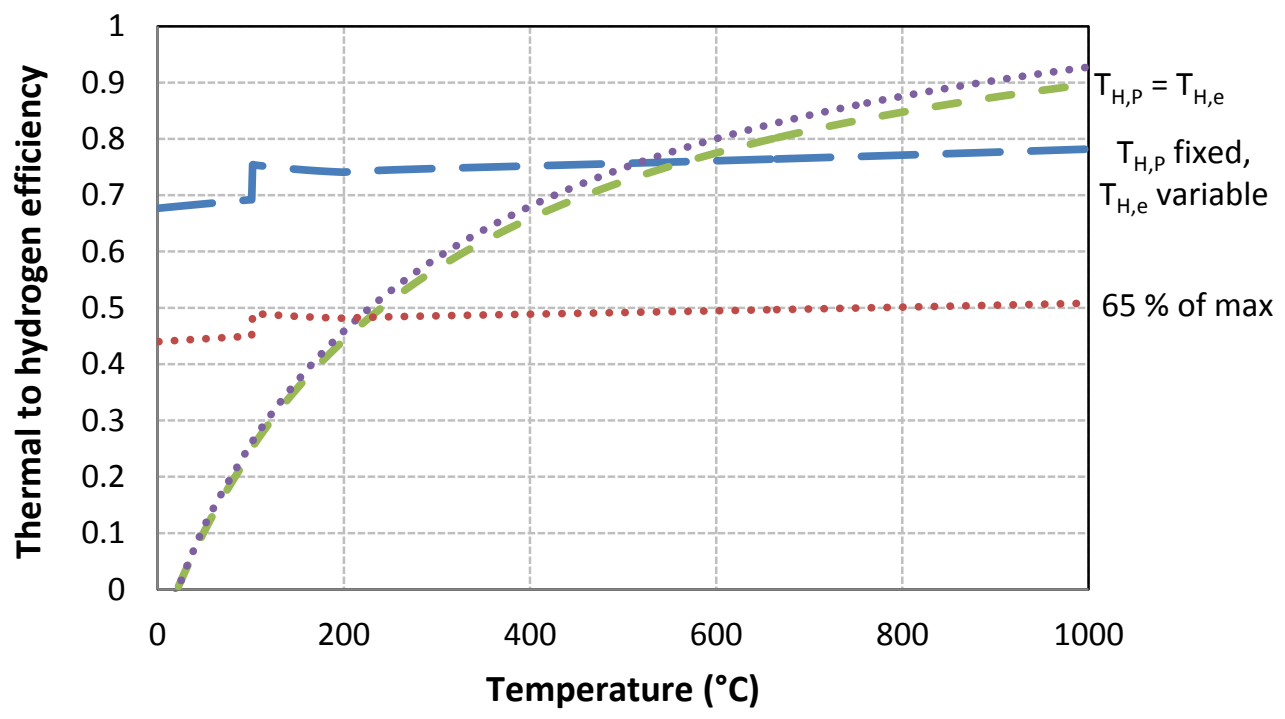

Figure 31: Calculated ideal thermal to hydrogen efficiencies for variable and fixed values of $T_{H, P}$. $T_{L}=20^{\circ} \mathrm{C}$; For fixed case, $T_{H, P}=566^{\circ} \mathrm{C}$.

This water splitting model were incorporated into an Excel calculator block within Aspen Plus $®$ (2009). The model receives a heat input into the water splitting process from Aspen Plus ${ }^{\circledR}$ (2009) and then calculates the corresponding electrical work requirement according to the ratios as shown in Figure 28. In the next step, the ideal thermal to hydrogen efficiency of the water splitting process at the electrolyser operating temperature, as specified within Aspen Plus ${ }^{\circledR}$ (2009), is calculated according to the model as shown in Figure 31 . This number is multiplied by a factor of $65 \%$ to account for the loss in thermal efficiency in a practical engineering process. A fraction of $65 \%$ was assumed, based on various studies done at the Idaho National Laboratory see Figure 26. A sample output of the Aspen Plus ${ }^{\circledR}$ (2009) electrolyser model is shown in Figure 32 and the implementation of this model in the overall process model is shown in Figure 33. Note that for this case, the thermal to hydrogen efficiency can be calculated as follows:

$$
\begin{gathered}
\eta_{H}=\frac{\Delta H_{R}}{Q_{t o t}}=\frac{\Delta H_{R}}{Q_{H, P}+Q_{H, e}} \\
\therefore \eta_{H}=\frac{\Delta H_{R}}{Q_{H, P}+\frac{Q_{H, e}}{\eta_{e}}}=\frac{465}{231+\frac{292}{0.42}}=\mathbf{0 . 5 0 2}
\end{gathered}
$$


The value calculated above corresponds exactly to the calculated thermal to hydrogen efficiency ( $65 \%$ of maximum efficiency) at $800{ }^{\circ} \mathrm{C}$ electrolyser operating temperature.

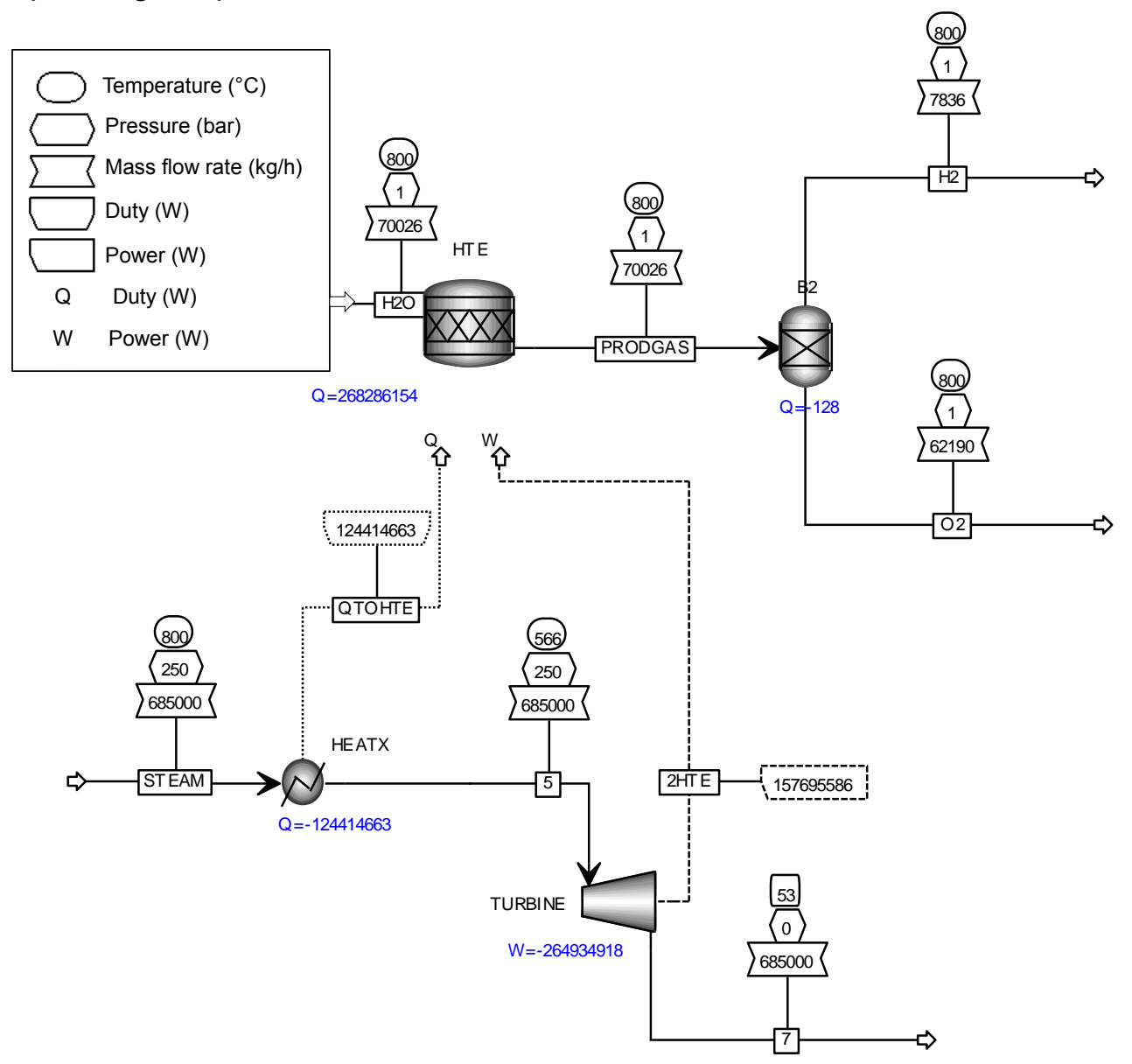

Figure 32: Sample of electrolyser model in Aspen Plus ${ }^{\circledR}$ (2009), showing heat and electricity input with resulting hydrogen production

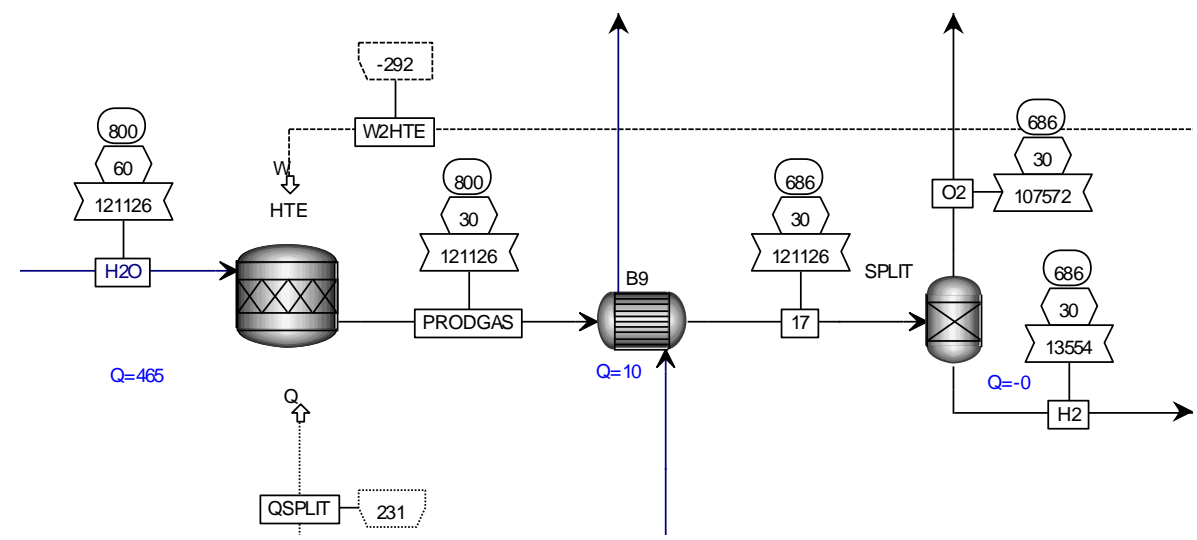

Figure 33: Implementation of electrolyser Aspen Plus ${ }^{\circledR}$ (2009), within the overall plant model (duty and power values in this figure are in MW) 


\subsection{Rankine cycle}

A cogeneration plant design should provide as much opportunity as possible for heat integration in order to optimise the overall energy efficiency of the plant. It was therefore imperative to make use of a steam power conversion cycle or Rankine cycle. This would enable steam generated in the gasification unit to be fed directly to the appropriate steam turbine, as well as provide a source of steam for use in other parts of the plant.

\subsubsection{Basis of design}

The design of the power conversion cycle was based on the design of the Chinese HTR-PM project. According to Zhang (2006), the designers of this demonstration plant deemed the more efficient Brayton cycle as too risky and opted to use a mature sub-critical Rankine cycle for the project. Their preliminary design is illustrated in Figure 34 , while the updated values are displayed in Table 11.

Table 11: Final design parameters of the HTR-PM steam power cycle (Zhang et al., $2006 \&$ 2009)

\begin{tabular}{|l|c|c|}
\hline Parameter & Unit & Value \\
\hline Rated electrical power & $\mathrm{MW}_{\mathrm{e}}$ & 210 \\
\hline Reactor total thermal power & $\mathrm{MW}_{\mathrm{t}}$ & $2 \times 250$ \\
\hline Electrical efficiency & $\%$ & 42 \\
\hline Main steam pressure & $\mathrm{bar}$ & 132.4 \\
\hline Main steam temperature & ${ }^{\circ} \mathrm{C}$ & 566 \\
\hline Main feed-water pressure & $\mathrm{bar}$ & 151 \\
\hline Main feed-water temperature & ${ }^{\circ} \mathrm{C}$ & 205 \\
\hline Main steam flow rate to turbine & $\mathrm{t} / \mathrm{h}$ & 673 \\
\hline
\end{tabular}

According to Zhang (2006), the design of the reheater is complex due to safety and structural issues, although the gain in efficiency is obvious. For the purposes of this study, a reheater was incorporated into the process model, although the design of the intermediate heat exchanger (or steam generator) was outside the scope of this project.

\subsubsection{Aspen Plus $®$ (2009) model of Rankine cycle}

A process model of the Rankine cycle was developed based on the parameters in Table 11. The following assumptions were made:

- All the turbines isentropic efficiencies assumed to be $90 \%$

- Pump efficiencies assumed to be $90 \%$

- LP turbine outlet pressure

- Assumed to be $11 \mathrm{kPa}$ (Çengel and Boles, 2011: 558) to reach a cycle efficiency of $42 \%$ 
- Resultant steam dryness factor is $92.4 \%$, which exceeds the minimum design specification of $88 \%$. It is well known that to avoid erosion of turbine blades the steam dryness factor at the turbine outlet should not be lower than $88 \%$. (Singh, 2006:245)

- Feed Water Heaters

- Assumed open feed water heaters in order to ease simulation convergence

- Bleed steam flow rate calculated with design specification in Aspen Plus ${ }^{\circledR}(2009)$ in order to heat feed water to saturation temperature at feed water heater operating pressure.

- Deaeration and feed water heating were accomplished in the deaerator.

- Only 2 feed water heaters was used to simplify the simulation. In practice, 5 or more feed water heating steps are common practice.

- Condenser design

- Assume $\mathrm{T}_{\text {wet bulb }}=12{ }^{\circ} \mathrm{C}$

- Cooling tower $\Delta \mathrm{T}=10^{\circ} \mathrm{C}$; thus $\mathrm{T}_{\text {cooling water }}=22^{\circ} \mathrm{C}$

- Assume minimum $\Delta \mathrm{T}=15^{\circ} \mathrm{C}$ for effective heat transfer, thus $\mathrm{T}_{\text {steam }}=37^{\circ} \mathrm{C}$ (at saturation pressure of $6.28 \mathrm{kPa}$ )

- This implies minimum condenser pressure is $6.28 \mathrm{kPa}$. The chosen condenser operating pressure of $11 \mathrm{kPa}$ is well above this value.

An illustration of the Aspen Plus ${ }^{\circledR}$ (2009) model of the Rankine cycle is shown in Figure 35. The thermodynamic efficiency or $1^{\text {st }}$ law efficiency of this cycle was calculated and the results are shown in Table 12 . A detailed exergy or $2^{\text {nd }}$ law analysis of this Rankine cycle was also conducted and is presented in Appendix C.

Table 12: Aspen Plus $®$ (2009) model calculation of the thermodynamic efficiency of the Rankine cycle

\begin{tabular}{|l|r|l|}
\hline WORK TERMS & -57.9 & $\mathrm{MW}$ \\
\hline W HPturbine & -82.3 & $\mathrm{MW}$ \\
\hline W IPturbine & -96.7 & $\mathrm{MW}$ \\
\hline W LPturbine & 0.031 & $\mathrm{MW}$ \\
\hline W pump1 & 0.29 & $\mathrm{MW}$ \\
\hline W pump2 & 3.2 & $\mathrm{MW}$ \\
\hline W pump3 & 1 & \\
\hline Generator efficiency (assumed) & 233.3 & $\mathrm{MW}$ \\
\hline NET ELECTRIC POWER & \multicolumn{2}{|l|}{} \\
\hline HEAT TERMS & 491.2 & $\mathrm{MW}$ \\
\hline Q boiler & 62.1 & $\mathrm{MW}$ \\
\hline Q reheat & 553.3 & $\mathrm{MW}$ \\
\hline TOTAL HEAT INPUT & $\mathbf{4 2 . 1 6 \%}$ \\
\hline 1st law efficiency & \multicolumn{2}{|l}{} \\
\hline
\end{tabular}




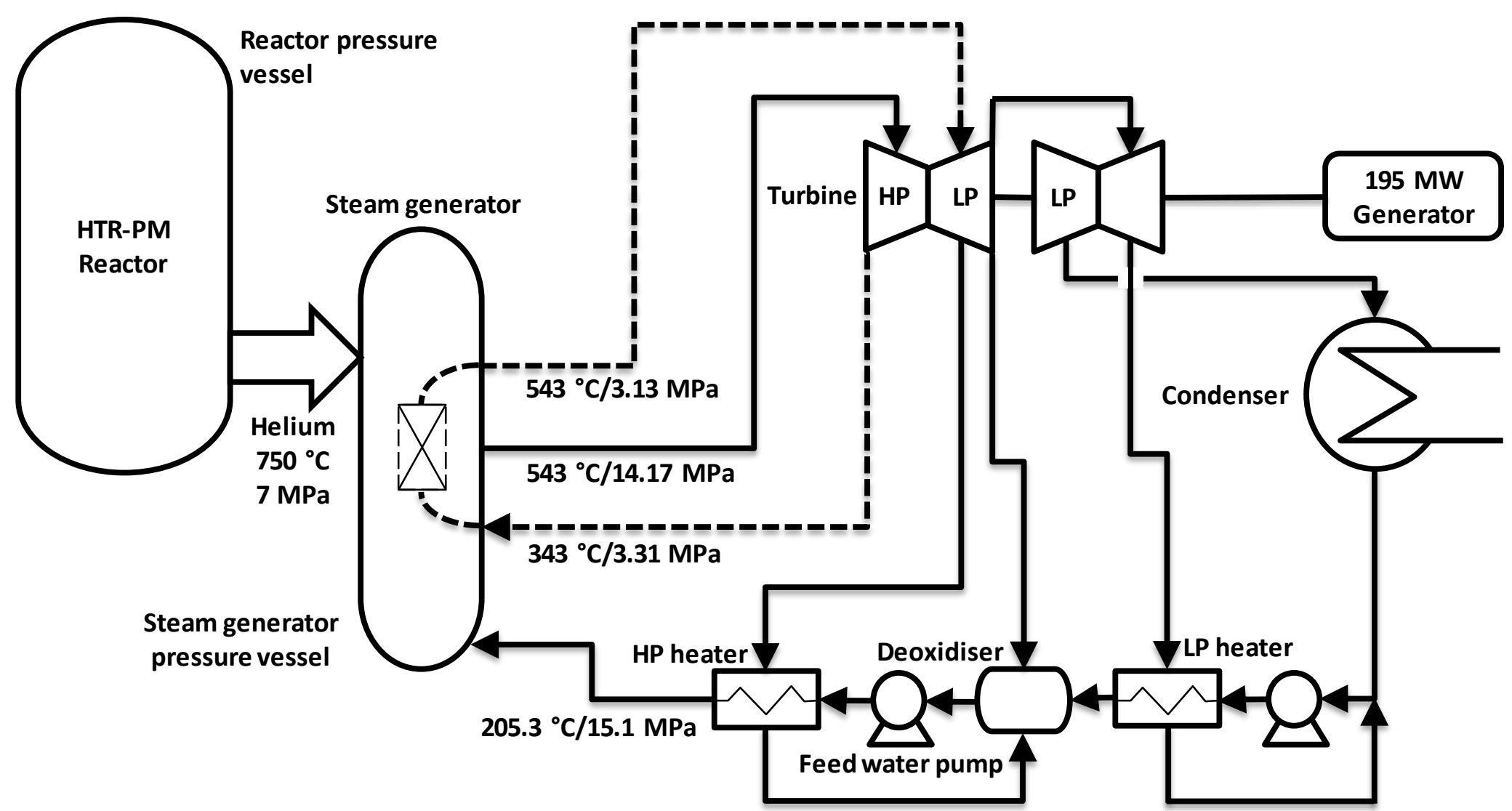

Figure 34: Conceptual design of the HTR-PM steam power conversion cycle (Zhang et al., 2006) 


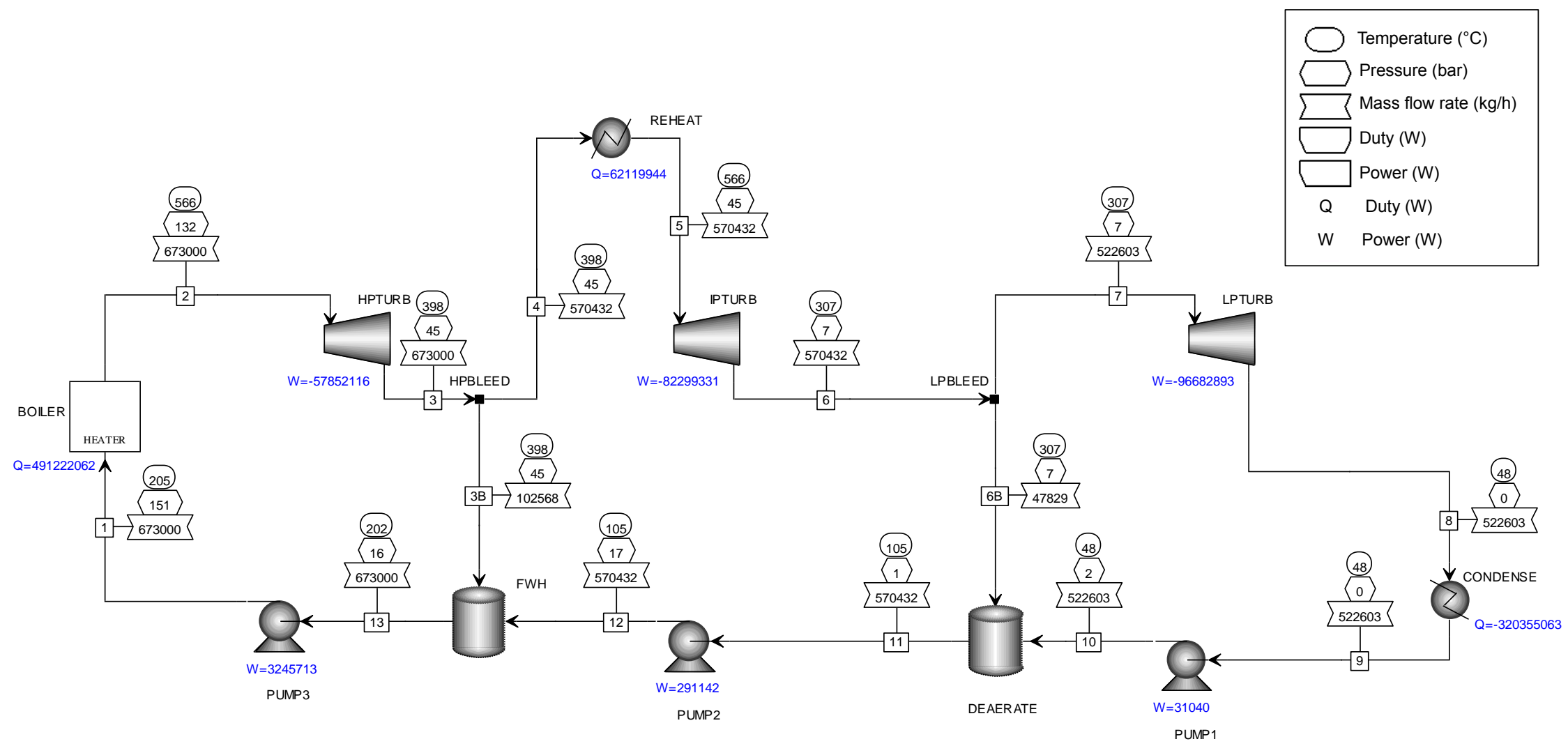

Figure 35: Aspen Plus ${ }^{\circledR}$ (2009) model of the steam power conversion (Rankine) cycle 


\subsection{Process integration}

After completion of the process models for the different units, the models were coupled to form an integrated cogeneration plant. The economic analysis of the cogeneration plant was outside the scope of the project, although economic considerations would ultimately play a significant role in the design of any process plant.

\subsubsection{Basis of design}

As mentioned in section 3.1, it was assumed that an economic optimum would result if the the air separation unit which supplies in the oxygen requirements of the gasification plant, was eliminated and replaced by a water splitting plant. Although a detailed economic analysis is outside the scope of this project, it was assumed that the reduction in capital costs due to the elimination of the air separation unit would represent the most feasible economic scenario and this assumption was therefore used as the basis of the design of the cogeneration plant. This required that the water splitting process also had to be sized to supply the gasifier's oxygen requirement.

\subsubsection{Utilities}

In a typical process plant, a few utility steam levels are available to meet in the plant's process heat requirements. In this study, three levels were chosen, namely high pressure (HP), medium pressure (MP) and low pressure (LP) steam. The process conditions of each steam level were designed to match the three steam turbine stages, which enabled optimal heat integration between the different sections of the cogeneration plant. The feed water conditions were based on the IEA GHG Report (IEA GHG Report PH4/19, 2003). The chosen steam conditions, as well as boiler feed water supply conditions, are shown Table 13. The maximum pressure indicates the steam generation pressure, while the minimum pressure specifies the steam pressure available for steam users. The temperature is the saturation temperature corresponding to the maximum pressure indicated.

Table 13: Steam utility process conditions

\begin{tabular}{|l|c|c|c|c|}
\hline \multirow{2}{*}{ UILITY } & \multicolumn{3}{|c|}{ Pressure (bar a) } & Temperature \\
\cline { 2 - 5 } & Max & Min & Turbine & $\left.{ }^{\circ} \mathbf{C}\right)$ \\
\hline High pressure (HP) & 150 & 140 & 132.4 & 342.2 \\
\hline Medium pressure (MP) & 55 & 50 & 45 & 270 \\
\hline Low Pressure (LP) & 9 & 8 & 7 & 175.4 \\
\hline
\end{tabular}

Waste heat in the different plant sections was used to generate the highest possible steam pressure. Throughout, a temperature difference of $20{ }^{\circ} \mathrm{C}$ was 
assumed between the steam outlet temperature and the hot stream outlet temperature. Waste heat were recovered from the process gas downstream of the gasifier and water gas shift unit and used to generate steam. Both the hot hydrogen and oxygen gas streams were cooled in HP and MP steam generators, before being fed to the water gas shift and gasifier units respectively. In the last cooling step, product gas was cooled to $38^{\circ} \mathrm{C}$, the temperature required by the acid gas removal unit (IEA GHG Report PH4/19, 2003). The heat duty and temperature driving force of this waste heat stream are suitable to preheat the boiler feed water and it was used to preheat the boiler feed water to $110^{\circ} \mathrm{C}$. All the generated steam was then fed to the appropriate steam turbine and used to generate additional electricity. The LP turbine outlet pressure was varied by means of a design specification within Aspen Plus $®$ (2009) in order to maintain a steam dryness factor of at least $90 \%$.

\section{Table 14: Boiler feed water supply conditions}

\begin{tabular}{|l|c|c|}
\hline Boiler Feed Water (BFW) supply & Pressure (bar g) & Temperature $\left({ }^{\circ} \mathbf{C}\right)$ \\
\hline High pressure (HP) & 175 & 112 \\
\hline Medium pressure (MP) & 70 & 111 \\
\hline Low Pressure (LP) & 15 & 110 \\
\hline Cold condensate supply & Atmospheric & 20 \\
\hline
\end{tabular}

\subsubsection{High Temperature Reactor model}

The High Temperature Reactor (HTR) was modelled as a simple heater block within Aspen Plus ${ }^{\circledR}$ (2009), with outlet pressure specified as 70 bar to match the Chinese HTR-PM design (refer to Figure 34). The reactor outlet temperature was varied between $850^{\circ} \mathrm{C}$ and $950{ }^{\circ} \mathrm{C}$, according to current HTR designs (refer to Table 2). As discussed in an INL report (Gandrik et al., 2011:13), the optimum HTR temperature for processes that use high temperature helium is between 35 and $50{ }^{\circ} \mathrm{C}$ higher than the required temperature range to account for the two intermediate heat exchangers between the HTR and the process. It was therefore assumed that the minimum HTR outlet temperature that could supply process heat at $800{ }^{\circ} \mathrm{C}$ to the water splitting process was $850^{\circ} \mathrm{C}$. The heat transfer process from the intermediate heat exchanger to the water splitting process was simulated in Aspen Plus $®$ (2009) by a heat stream only, assuming that the heat will be available at $800^{\circ} \mathrm{C}$. The detailed physical design of the intermediate heat exchangers is outside the scope of this project, but it was assumed that $5 \%$ of the high temperature heat from the heat stream to the water splitting process was lost to the environment.

The number of HTR's was chosen to supply the required heat to the water splitting unit to meet the gasifier oxygen demand at an HTR outlet temperature 
of $850^{\circ} \mathrm{C}$. The high temperature intermediate heat exchanger outlet temperature was specified as $750{ }^{\circ} \mathrm{C}$, which required about $1500 \mathrm{MW}_{\text {th }}$ to supply enough heat at $800{ }^{\circ} \mathrm{C}$ to the water splitting unit. It was therefore decided that the thermal heat requirement should be met by $6 \times 250 \mathrm{MW}_{\text {th }}$ HTR's, based on the HTR-PM design. Any additional heat from the reactor was routed past the intermediate heat exchanger and fed directly to the steam generator by means of a design specification block in Aspen Plus ${ }^{\circledR}$ (2009). The fraction of helium that bypasses the high temperature intermediate heat exchanger would therefore increase with increasing HTR outlet temperatures.

The temperature difference across the HTR was maintained at $450{ }^{\circ} \mathrm{C}$ in order to limit thermal stresses to the reactor internals. Although the HTR-PM is designed for a reactor differential temperature of $500{ }^{\circ} \mathrm{C}$ (refer to Table 2), it was assumed that a temperature difference of $450{ }^{\circ} \mathrm{C}$ over the reactor is a more conservative design value. This assumption would increase the helium flow rate slightly compared to the HTR-PM design, although the HTR thermal load would remain constant. This means that the exact temperature difference over the HTR is irrelevant for the purposes of this study. The temperature difference across the HTR was maintained at $450{ }^{\circ} \mathrm{C}$ by varying the cooling water flow rate to the steam generator by means of a design specification in Aspen Plus ${ }^{\circledR}$ (2009). The Aspen Plus ${ }^{\circledR}$ (2009) model of the HTR and helium loop is shown in Figure 36, showing the coupling of the Rankine steam cycle to the steam generator. The steam generator also includes an internal reheater that reheats steam from the HP turbine outlet before entering the MP turbine.

\subsubsection{General considerations for process integration}

The different process units were integrated in such a way so as to minimise exergy destruction. Consider the rate form of equation 2-10 for the exergy balance over a heat exchanger:

$$
\dot{X}_{\text {in }}-\dot{X}_{\text {out }}-\dot{X}_{\text {destroyed }}=d X_{\text {system }} / d t
$$

Substituting equation 2-6 into equation $3-14$, it follows that the exergy balance at steady state reduces to

$$
\begin{gathered}
\dot{Q}\left(1-\frac{T_{0}}{T}\right)_{\text {in }}-\dot{Q}\left(1-\frac{T_{0}}{T}\right)_{\text {out }}-\dot{X}_{\text {destroyed }}=0 \\
\dot{Q} T_{0}\left(\frac{1}{T_{\text {out }}}-\frac{1}{T_{\text {in }}}\right)=\dot{X}_{\text {destroyed }}
\end{gathered}
$$




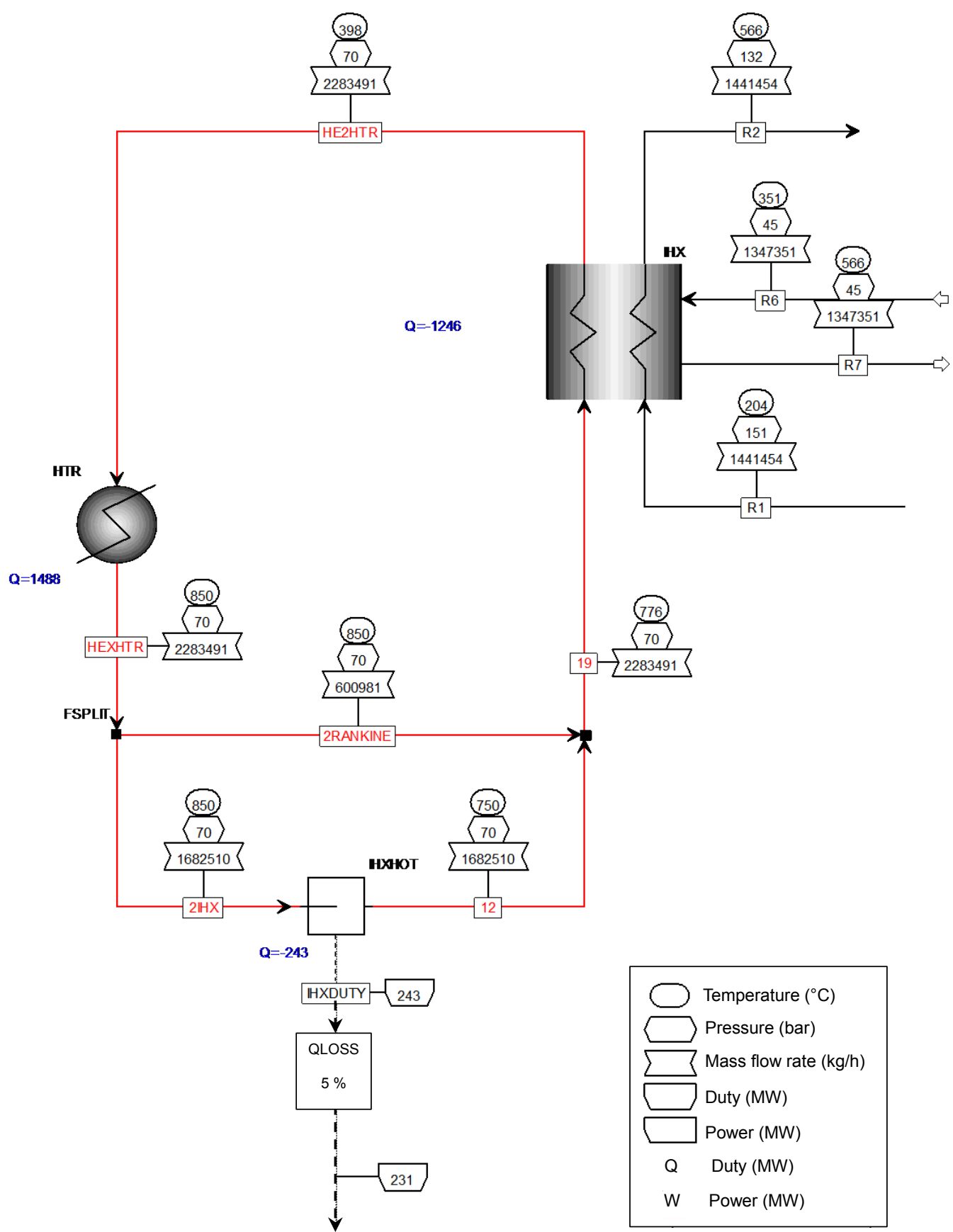

Figure 36: Aspen Plus $\AA$ (2009) model of high temperature reactor with helium loop and intermediate heat exchangers 
Equation 3-16 implies that the temperature difference over a heat exchanger should be minimised in order to minimise exergy destruction in the heat exchanger. In practice, this means that heat streams should be matched as closely as possible to optimise the energy efficiency of a heat exchanger. For this reason, the $800{ }^{\circ} \mathrm{C}$ steam that is required for the water splitting process, was sourced from the steam generator at $566{ }^{\circ} \mathrm{C}$ and heated in two steps to the desired temperature. Steam from the steam generator at $566^{\circ} \mathrm{C}$ and 132.4 bar was first flashed adiabatically to 60 bar to reduce the required pipe schedule for this stream. In the first heating step, the flashed steam at $537^{\circ} \mathrm{C}$ and 60 bar was heated by the product stream from the electrolysis unit to $666^{\circ} \mathrm{C}$. In the second heating step, it was assumed that the hot quenched gas from the gasifier at $900{ }^{\circ} \mathrm{C}$ could be used to heat the steam to $800{ }^{\circ} \mathrm{C}$ in the syngas cooling section.

The electric power required for the water splitting process was sourced from the Rankine cycle power generation unit, while all additional electricity production was made available to the electricity grid. Gas compressors and pumps were added where necessary to raise the pressure level of process fluids. Throughout, it was assumed that all compressors operated at $88 \%$ isentropic efficiency, while all pumps were specified as $90 \%$ efficient. The process flow diagram of the integrated cogeneration plant is shown in Figure 37. 
Stellenbosch University http://scholar.sun.ac.za



Figure 37: Process flow diagram of Aspen Plus $\AA^{\circledR}$ (2009) model of integrated cogeneration plant

61 


\section{Results and discussion}

\subsection{Process performance of the cogeneration plant}

In accordance with a similar study by Harvego et al. (2008), two figures of merit were considered in assessing the performance of the process, namely synthesis (syngas) gas production efficiency and carbon utilisation. The syngas production efficiency is defined as the ratio of the energy output of the process to the energy input. The energy input is defined as the sum of the heat addition to the process by the HTR and the lower heating value of the coal consumed, while the energy output is the sum of the lower heating value of the produced syngas and the electric power production that is fed to the grid. The carbon efficiency or carbon utilisation is defined as the ratio of the mass of carbon in the syngas product to the mass of carbon in the coal feed. The control volume for the calculation of the syngas production efficiency of the cogeneration plant is illustrated in Figure 38.



Figure 38: Calculation of the syngas production efficiency

$$
\begin{aligned}
& \eta_{\text {syngas }}=\frac{\text { Heating value of syngas produced }+ \text { Electricity produced }}{\text { Heat addition to process }+ \text { Heating value of coal consumed }} \\
& \therefore \eta_{\text {syngas }}=\frac{\mathrm{N}_{\mathrm{H}_{2}} \mathrm{LHV}_{\mathrm{H}_{2}}+\mathrm{N}_{\mathrm{CO}} \mathrm{LHV}_{\mathrm{CO}}+\mathrm{W}_{\text {grid }}}{\mathrm{Q}_{\mathrm{th}, \mathrm{HTR}}+\mathrm{N}_{\text {coal }} \mathrm{LHV} \text { coal }} \\
& =\frac{(28141.8 / 3600)(121)+(195514.1 / 3600)(10.1)+278.5}{1487.5+(140000 / 3600)(34)} \\
& =\mathbf{6 3 . 1 \%}
\end{aligned}
$$

Carbon utilisation $=\frac{\text { Mass carbon in } \mathrm{CO} \text { in the syngas product }}{\text { Mass carbon in the coal feed }}$

$\therefore$ Carbon utilisation $=\frac{\mathrm{N}_{\mathrm{CO}} \frac{\mathrm{MW}_{\mathrm{C}}}{\mathrm{MW}_{\mathrm{CO}}}}{\text { Mass } \mathrm{C} \text { in MAF coal } \times \text { Mass MAF coal to gasifier }}$

$$
\begin{aligned}
& =\frac{(195514.1) \cdot \frac{12.01}{28.01}}{0.838 \times 140000} \\
& =71.5 \%
\end{aligned}
$$


Table 15: Results of cogeneration plant Aspen Plus ${ }^{\circledR}$ (2009) model used in calculation of syngas production efficiency and carbon utilisation of process

\begin{tabular}{|c|c|c|}
\hline \multicolumn{3}{|l|}{ ENERGY INPUT } \\
\hline HTR thermal energy & 1487.5 & MW \\
\hline Coal feed & 140000 & $\mathrm{~kg} / \mathrm{h}$ \\
\hline LHV SA Coal & 34 & $\mathrm{MJ} / \mathrm{kg}$ \\
\hline LHV coal feed & 1322.2 & MW \\
\hline \multicolumn{3}{|l|}{ ENERGY OUTPUT } \\
\hline Power produced & 294.9 & MW \\
\hline Electricity used in process & 16.4 & MW \\
\hline Net electricity to grid & 278.5 & MW \\
\hline \multicolumn{3}{|l|}{ Synthesis gas } \\
\hline $\mathrm{H}_{2}$ mass flow & 28141.8 & $\mathrm{~kg} / \mathrm{h}$ \\
\hline CO mass flow & 195514.1 & $\mathrm{~kg} / \mathrm{h}$ \\
\hline $\mathrm{LHV} \mathrm{H}_{2}$ & 121 & $\mathrm{MJ} / \mathrm{kg}$ \\
\hline LHV CO & 10.1 & $\mathrm{MJ} / \mathrm{kg}$ \\
\hline $\mathrm{N}_{\mathrm{H} 2} \mathrm{LHV}_{\mathrm{H} 2}$ & 945.9 & MW \\
\hline $\mathrm{N}_{\mathrm{COLHV}} \mathrm{CO}_{\mathrm{C}}$ & 549.2 & MW \\
\hline LHVsyngas & 1495.1 & MW \\
\hline
\end{tabular}

Table 16: Electricity users in Aspen Plus $®$ (2009) model of cogeneration plant

\begin{tabular}{|l|l|r|l|}
\hline Equipment name & Description & Electricity requirement \\
\hline PUMPR1 & Pump & 60.3 & $\mathrm{~kW}$ \\
\hline PUMPR2 & Pump & 620.4 & $\mathrm{~kW}$ \\
\hline PUMPR3 & Pump & 6940.2 & $\mathrm{~kW}$ \\
\hline PUMPR4 & Pump & 4.6 & $\mathrm{~kW}$ \\
\hline O2COMPR & Compressor & 1384.0 & $\mathrm{~kW}$ \\
\hline RECOMPR & Compressor & 5164.2 & $\mathrm{~kW}$ \\
\hline CO2COMPR & Compressor & 232.4 & $\mathrm{~kW}$ \\
\hline PUMPBFW & Pump & 98.8 & $\mathrm{~kW}$ \\
\hline PUMPHPBFW & Pump & 1577 & $\mathrm{~kW}$ \\
\hline PUMPMPBFW & Pump & 310.5 & $\mathrm{~kW}$ \\
\hline PUMPLPBFW & Pump & 9.2 & $\mathrm{~kW}$ \\
\hline PUMPSCRU & Pump & 40.9 & $\mathrm{~kW}$ \\
\hline TOTAL & \multicolumn{16}{|l}{} & MW \\
\hline
\end{tabular}


The calculated syngas production efficiency of $63.1 \%$ corresponds very well with that of a similar study by INL (Harvego et al., 2008), who obtained around $65 \%$ in their analysis (see Figure 39). Although Harvego et al. (2008) chose a different process route (coal gasifier followed by reverse water gas shift reactor), reactants and products of both systems remain the same. The current study chose a commercial gasifier and water gas shift combination instead, due to the high temperatures required to achieve significant conversion of $\mathrm{CO}_{2}$ in a reverse water gas shift unit. A sensitivity analysis using the Aspen Plus ${ }^{\circledR}$ (2009) "RGibbs" reactor model revealed that only $40 \%$ of the $\mathrm{CO}_{2}$ was converted to $\mathrm{CO}$ at $800{ }^{\circ} \mathrm{C}$ (refer to Table 17). Considering the fact that limited heat sources at very high temperatures are available, a reverse water gas shift (RWGS) process step seems to be an unpractical way of reducing the $\mathrm{CO}_{2}$ content of the gasification product gas. Commercial entrained flow gasifiers provide a very low $\mathrm{CO}_{2}$ content gas and actually drives the RWGS reaction inside the gasifier due to its high operating temperature of about $1500{ }^{\circ} \mathrm{C}$. However, a WGS unit will be required to adjust the $\mathrm{H}_{2} / \mathrm{CO}$ ratio of the syngas for the FT process. The WGS unit has the additional benefit that its high outlet temperatures can be used for waste heat recovery. In effect, the exothermic WGS reaction liberates the chemical potential energy in the low $\mathrm{CO}_{2}$ content syngas stream, which can be used to generate steam and electricity in the Rankine cycle. In this way, the high exergy in the gasifier due to its very high temperatures is recovered more effectively, which results in an improvement in the overall thermal efficiency of the gasification process.

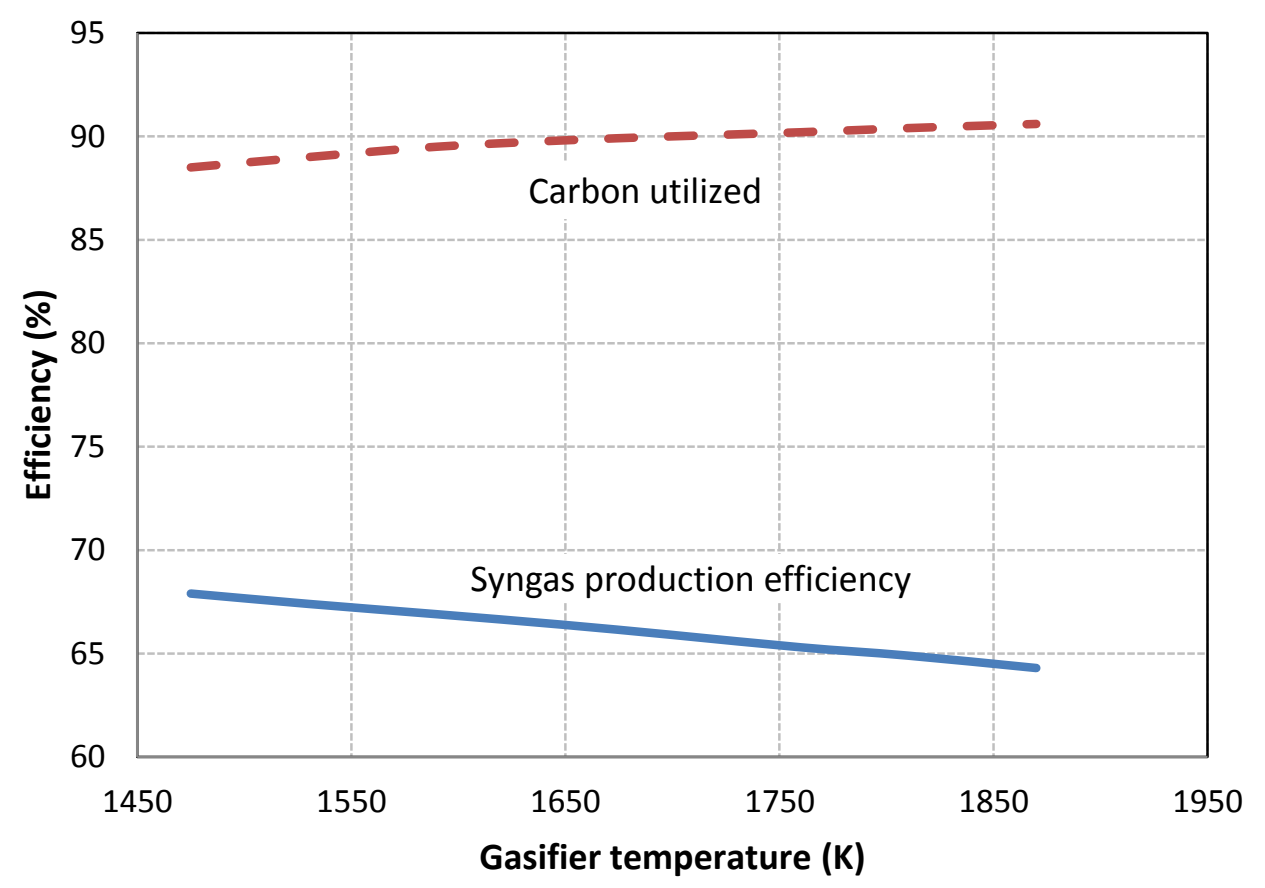

Figure 39: Results of system analysis of nuclear-assisted syngas production from coal by INL (Harvego et al., 2008) 
Table 17: Sensitivity analysis in feed temperature for RWGS reaction with a feed composition of $55 \% \mathrm{H}_{2}, 15 \% \mathrm{CO}, 21 \% \mathrm{CO}_{2}, 0.2 \% \mathrm{~N}_{2}, 8.8 \% \mathrm{H}_{2} \mathrm{O}$.

\begin{tabular}{|c|c|}
\hline Reactor feed temperature $\left({ }^{\circ} \mathbf{C}\right)$ & $\mathbf{C O}_{2}$ conversion \\
\hline 500 & $8 \%$ \\
\hline 600 & $20 \%$ \\
\hline 700 & $30 \%$ \\
\hline 800 & $40 \%$ \\
\hline
\end{tabular}

The cogeneration plant's calculated carbon utilisation of $71.5 \%$ is substantially lower than the figure of around $90 \%$ of the INL study (refer to Figure 39). The difference is due to the fact that all the HTR thermal energy is dedicated to syngas production in the INL study, whereas the current study only utilised a part of the HTR energy for hydrogen (and syngas) production and aimed to meet the gasifier's oxygen demand instead. The rest of the HTR's thermal energy was used for electricity production. However, if all the electricity of the Rankine cycle is used for hydrogen (and syngas) production (as discussed in the following sections), the carbon utilisation increases to about $86 \%$ (refer to Figure 45), which corresponds well to the approximately $90 \%$ carbon utilisation of the INL study (Harvego et al., 2008). Compared to a conventional process in which only about $30 \%$ of the carbon ends up in the product syngas (Harvego et al., 2008:5), these results are extremely good.

Usually an acid gas removal plant is required to remove impurities and $\mathrm{CO}_{2}$ before the Fischer Tropsch process. It was therefore assumed that $\mathrm{CO}_{2}$ was available from the acid gas removal unit for use as a coal transport gas to the gasifier. The separation of $\mathrm{CO}_{2}$ from the syngas (for use as coal feed gas) resulted in a drop in $\mathrm{CO}_{2}$ mole fraction in the final product gas of $2.5 \%$ to $9.1 \%$. According to Table A-3 in Appendix A, the use of $\mathrm{CO}_{2}$ as coal transport gas only increases the $\mathrm{CO}_{2}$ fraction in the gasifier product from about $1 \%$ to $2 \%$. This implies that some of the $\mathrm{CO}_{2}$ is converted back into $\mathrm{CO}$ and actually ends up in the final product. The conversion of $\mathrm{CO}_{2}$ occurs at very high temperatures in the gasifier through the reverse water gas shift (RWGS) reaction. In an increasingly carbon constrained world, the only other alternative would be to sequester the $\mathrm{CO}_{2}$ at high cost, if a suitable carbon sequestration site is available. The use of $\mathrm{CO}_{2}$ as coal transport gas therefore provides an elegant way of reducing carbon emissions, while at the same time increasing the carbon utilisation of the process. 


\subsection{Base case process performance}

In order to evaluate the performance of the cogeneration plant, it was compared with a base case scenario. The base case was modelled, using an HTR reactor with a reactor outlet temperature of $750^{\circ} \mathrm{C}$ as energy source, coupled to mature technologies, namely low temperature electrolysis (LTE) units for hydrogen production, entrained flow gasification and water gas shift technology. The process flow diagram of the base case can be seen in Figure 40, as modelled in Aspen Plus $®$ (2009). The main differences between the base case and the cogeneration plant are listed in Table 18.

Table 18: Differences between cogeneration plant and base case simulation

\begin{tabular}{|l|l|l|}
\cline { 2 - 3 } \multicolumn{1}{c|}{} & Cogeneration plant & Base case \\
\hline $\mathbf{H}_{2}$ production & HTE process & Standard LTE technology \\
\hline $\begin{array}{l}\text { Electrolyser } \\
\text { energy }\end{array}$ & $\begin{array}{l}\text { Combination of heat from } \\
\text { HTR and electricity from } \\
\text { Rankine cycle }\end{array}$ & $\begin{array}{l}\text { Electricity from Rankine } \\
\text { cycle. Feed water is } \\
\text { preheated with } \mathrm{H}_{2} \\
\text { product to } 80^{\circ} \mathrm{C} .\end{array}$ \\
\hline $\begin{array}{l}\text { HTR outlet } \\
\text { temperature }\end{array}$ & 850 to $950^{\circ} \mathrm{C}$ & ${ }^{\circ} \mathrm{C}$ \\
\hline Steam for gasifier & Sourced from Rankine cycle & $\begin{array}{l}\text { Generated in gasifier's } \\
\text { syngas cooler }\end{array}$ \\
\hline
\end{tabular}

Established and commercially available low temperature electrolysis technology from NEL Hydrogen (NEL Hydrogen atmospheric electrolyser technical data, [S.a]) was chosen for the study. The electricity needed to produce the required amount of oxygen for the gasifier was calculated as shown in Table 19. The base case model's performance was calculated in the same manner as explained in section 4.1 and compared to the cogeneration plant. The results are presented in Table 20.

Table 19: Calculation of the electricity requirement for atmospheric low temperature electrolysis technology (NEL Hydrogen atmospheric electrolyser technical data, [S.a])

\begin{tabular}{|l|r|l|}
\hline Assumptions: & 4.1 & $\mathrm{kWh} / \mathrm{m}^{3}{ }_{\mathrm{H}} \mathrm{H}_{2}$ \\
\hline LTE electricity requirement & 3.6 & $\mathrm{MJ} / \mathrm{kWh}$ \\
\hline Energy in 1kWh & 14.8 & $\mathrm{MJ} / \mathrm{m}^{3}{ }_{\mathrm{n}} \mathrm{H}_{2}$ \\
\hline LTE electricity requirement & $42 \%$ & \\
\hline Assumed electricity generation thermal efficiency & \multicolumn{2}{|l|}{} \\
\hline Process requirement: & 6723.5 & $\mathrm{kmol} / \mathrm{h}$ \\
\hline Hydrogen production & 150701.7 & $\mathrm{~m}^{3}{ }_{\mathrm{n}} / \mathrm{h}$ \\
\hline Hydrogen production & 617.9 & $\mathbf{M W}$ \\
\hline Electricity requirement for $\mathrm{H}_{\mathbf{2}}$ production &
\end{tabular}


Table 20: Comparison of cogeneration plant process performance with base case scenario

\begin{tabular}{|l|c|c|}
\hline Performance parameter & Cogeneration plant & Base case \\
\hline Syngas production efficiency & $63.1 \%$ & $54.6 \%$ \\
\hline Carbon utilisation & $71.5 \%$ & $71.5 \%$ \\
\hline Electrolyser thermal to $\mathrm{H}_{2}$ efficiency & $50.2 \%$ & $36.1 \%$ \\
\hline
\end{tabular}

If the syngas production efficiency of the cogeneration plant is compared to the base case, the drop of $8.5 \%$ from $63.1 \%$ to $54.6 \%$ can be attributed to the lower thermal to hydrogen efficiency of the low temperature electrolysis unit. The thermal to hydrogen efficiency of the chosen low temperature electrolysis (LTE) technology was calculated as $36.1 \%$, which compares well with the expected value of around $35 \%$ for conventional LTE technology (O'Brien, 2008). However, the technical risks associated with commercially unproven HTR and water splitting technologies will have to be mitigated before the possible gains in thermal and cost efficiency could be realised. 


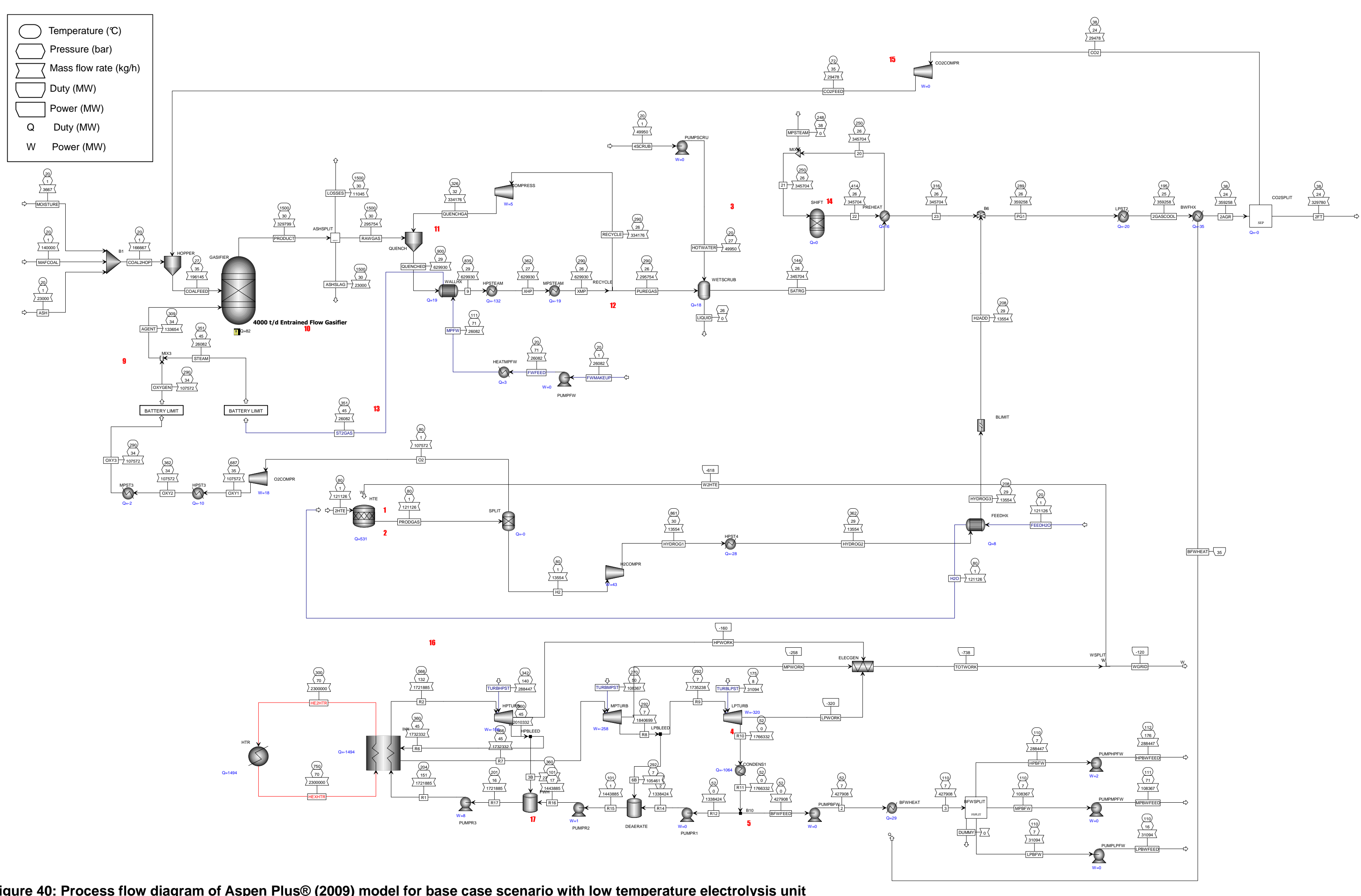




\subsection{Optimum reactor outlet temperature}

A simple exergy analysis was performed to determine the optimum reactor outlet temperature (ROT) for the maximum exergy (and thus energy) efficiency of the cogeneration plant. The influence of the reactor outlet temperature was mainly in the helium coolant loop, which includes the HTR, the hot intermediate heat exchanger (Hot $\mathrm{IHX})$ and the main intermediate heat exchanger or steam generator (IHX). Although the process conditions in the helium loop resulted in a slight variation in the heat duty of the steam generator and the amount of electricity produced, an exergy analysis over the helium loop is sufficient to capture the changes in exergetic efficiency of the whole cogeneration plant since all process parameters stay constant in the rest of the plant. This simplified approach could therefore be used as a means of determining the optimum HTR outlet temperature corresponding to the maximum overall cogeneration plant efficiency.

The exergy supply from the HTR was calculated, assuming an environmental temperature, $\mathrm{T}_{0}$ of $293 \mathrm{~K}$.

$$
\dot{X}_{\text {heat }}=\left(1-\frac{T_{0}}{T}\right) \dot{Q}
$$

The exergy destruction in the hot intermediate heat exchanger and steam generator was calculated as follows:

$$
\dot{Q} T_{0}\left(\frac{1}{T_{\text {out }}}-\frac{1}{T_{\text {in }}}\right)=\dot{X}_{\text {destroyed }}
$$

A sample calculation for the case with the HTR outlet temperature of $850{ }^{\circ} \mathrm{C}$ is shown in Table 21. The same procedure was repeated for an HTR temperature of $900{ }^{\circ} \mathrm{C}$ and $950{ }^{\circ} \mathrm{C}$. The total exergy destruction in the helium loop for different reactor outlet temperatures are presented in Figure 41.

Table 21: Sample calculation of exergy destruction in helium loop for an HTR outlet temperature of $850^{\circ} \mathrm{C}$

\begin{tabular}{|l|l|l|}
\hline \multicolumn{3}{|c|}{ HTR } \\
\hline$\dot{Q}_{\text {out }}$ & 1487.5 & $\mathrm{MW}$ \\
\hline $\mathrm{T}_{\text {out }}$ & 850 & ${ }^{\circ} \mathrm{C}$ \\
\hline$\dot{\mathrm{X}}_{\text {out }}$ & 1099.4 & $\mathrm{MW}$ \\
\hline & \multicolumn{2}{|c|}{} \\
\hline$\dot{\mathrm{X}}_{\text {supplied }}$ & 1099.4 & $\mathrm{MW}$ \\
\hline
\end{tabular}




\begin{tabular}{|c|c|c|}
\hline \multicolumn{3}{|c|}{$\begin{array}{l}\text { Hot intermediate } \\
\text { heat exchanger }\end{array}$} \\
\hline$\dot{Q}_{\text {in }}$ & 242.7 & MW \\
\hline$T_{\text {in }}$ & 850 & ${ }^{\circ} \mathrm{C}$ \\
\hline$\dot{\mathrm{X}}_{\text {in }}$ & 179.4 & MW \\
\hline$\dot{Q}_{\text {out }}$ & 242.7 & MW \\
\hline$T_{\text {out }}$ & 750 & ${ }^{\circ} \mathrm{C}$ \\
\hline$\dot{X}_{\text {out }}$ & 173.2 & MW \\
\hline$\dot{X}_{\text {destroyed }}$ & 6.2 & MW \\
\hline \multicolumn{3}{|c|}{ Steam generator } \\
\hline$\dot{Q}_{\text {in }}$ & 1244.8 & MW \\
\hline$T_{\text {in }}$ & 776.3 & ${ }^{\circ} \mathrm{C}$ \\
\hline$\dot{X}_{\text {in }}$ & 897.3 & MW \\
\hline$\dot{Q}_{\text {out }}$ & 1244.8 & MW \\
\hline$T_{\text {out }}$ & 566 & ${ }^{\circ} \mathrm{C}$ \\
\hline$\dot{X}_{\text {out }}$ & 810.2 & MW \\
\hline$\dot{X}_{\text {des }}$ & 87.1 & MW \\
\hline
\end{tabular}

$\therefore$ Total exergy destroyed in helium loop $=93.3 \mathrm{MW}$

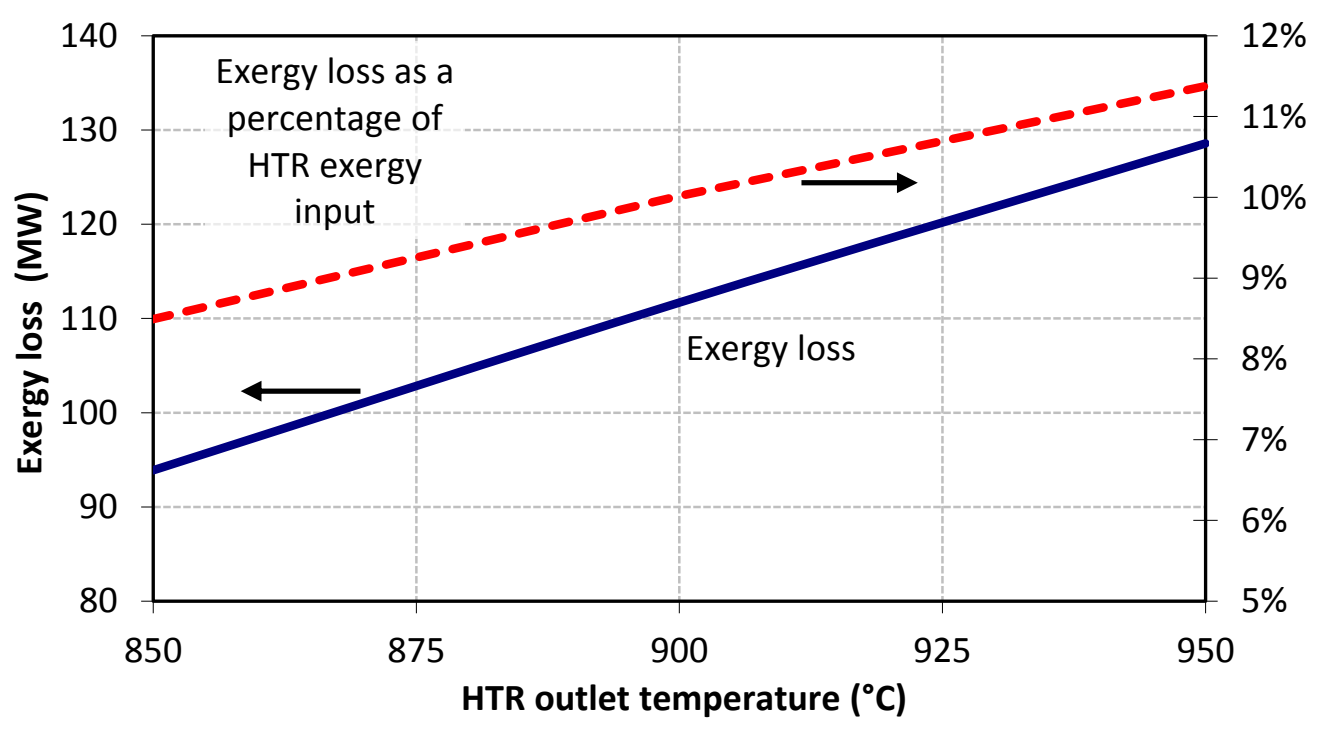

Figure 41: Effect of HTR outlet temperature on exergy efficiency in helium loop

The results clearly illustrate that the exergy loss in the helium loop increases with increasing HTR reactor outlet temperature. It is obvious from results in Figure 41 that the optimum HTR reactor outlet temperature for minimum 
exergy loss (and thus maximum energy efficiency) is $850^{\circ} \mathrm{C}$. This is a significant result, considering the concerns raised about the safety of HTR reactors, especially at very high temperatures. The answer matches that of a recent study by INL, that found the optimum HTR outlet temperature for the production of high temperature steam for electrolysis and hydrogen production to be $850{ }^{\circ} \mathrm{C}$ (Gandrik et al., 2011). Note that $850{ }^{\circ} \mathrm{C}$ is the minimum temperature at which the requirement for the high temperature electrolysis process of heat at $800^{\circ} \mathrm{C}$ can still be met, considering the presence of two intermediate heat exchangers.

The INL study included a sensitivity analysis to determine the optimum reactor outlet temperature (ROT) for generating primary and secondary outputs from an HTR coupled to a wide variety of chemical and power producing processes. It was found that the optimum reactor outlet temperature varies between $750{ }^{\circ} \mathrm{C}$ to $950{ }^{\circ} \mathrm{C}$, depending on the specific process coupled to the HTR. The INL study concluded that if the HTR is used only as heat source for electricity generation, the optimum HTR outlet temperature is $950{ }^{\circ} \mathrm{C}$. These results are consistent with the Carnot principle and implies the utilisation of a direct Brayton cycle for electricity production. The main findings of the INL study are shown in Figure 42.

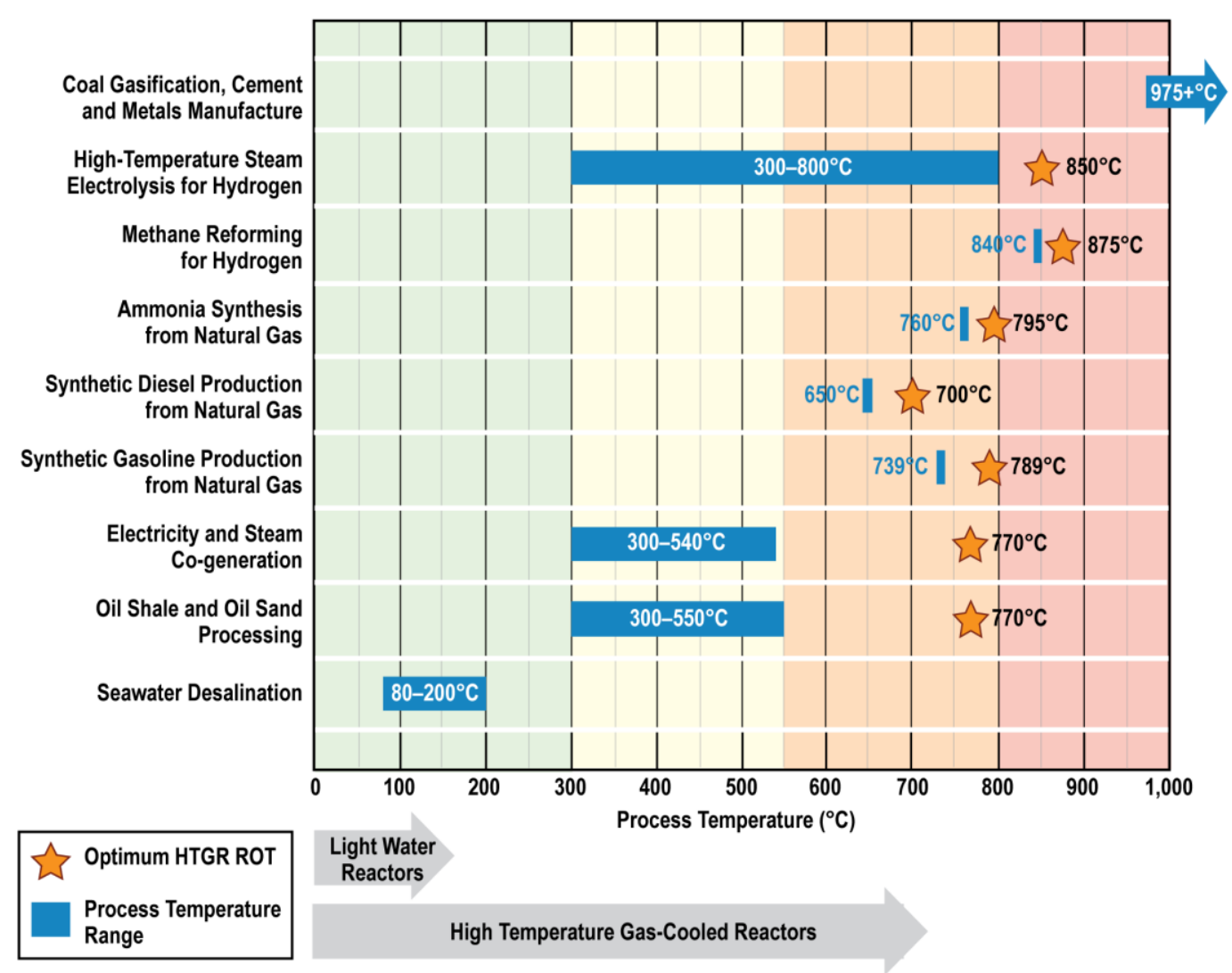

Figure 42: The results of a study on the optimum HTR outlet temperatures for various industrial processes (Gandrik et al., 2011) 


\subsection{Cogeneration plant reactor outlet temperature dependence study}

In all the previous simulations, the hot intermediate heat exchanger only provided enough heat to the water splitting unit to meet in the gasifier oxygen demand. The aim of the cogeneration plant reactor outlet temperature dependence study was to produce as much oxygen as possible with the available high temperature heat from the HTR and measure its effect on the rest of the plant's performance. As expected, more oxygen production with its associated hydrogen production, requires lower water gas shift conversion of $\mathrm{CO}$ in the synthesis gas to meet a $\mathrm{H}_{2} / \mathrm{CO}$ ratio of 2 in the product gas. Although this results in a lower $\mathrm{CO}_{2}$ fraction in the product gas (and therefore higher carbon utilisation), it comes at a penalty of higher electricity requirement to the water splitting unit. Consequently, electricity supply to the grid will reduce with increasing carbon utilisation and will ultimately result in electricity import from the grid. To study the possible operating modes of the cogeneration plant, the simulation model of the plant was adapted as follows:

- The helium bypass stream around the hot intermediate heat exchanger was set to zero, which meant that all the heat between the outlet temperature of the HTR to $750{ }^{\circ} \mathrm{C}$ (the specified outlet temperature of the hot intermediate heat exchanger) was used to provide thermal energy for water splitting.

- As discussed previously, the minimum required HTR outlet temperature was $850{ }^{\circ} \mathrm{C}$ in order to meet the heat requirements of the high temperature electrolysis unit. This temperature was increased in increments, while the thermal efficiency and carbon utilisation were calculated in the same manner as previously for each reactor outlet temperature (refer to equation 4-1 and 4-2).

- The additional oxygen flow (higher than the required gasifier demand) was calculated and it was assumed that it could be sold at market value.

- The electricity production to the grid was calculated as before, although the electricity demand of the water splitting unit required electricity import at higher hydrogen production rates. It was assumed that electricity was available from the grid at Eskom tariffs.

- All hydrogen was added to the synthesis gas stream, which implied that a lower CO conversion was required in the WGS unit to meet a $\mathrm{H}_{2} / \mathrm{CO}$ ratio of 2 in the product gas. The $\mathrm{CO}$ conversion was reduced by increasing the bypass flow of the synthesis gas around the WGS unit by means of a design specification within Aspen Plus ${ }^{\circledR}(2009)$.

The modified sections of the process flow diagram are shown in Figure 43 and Figure 44. Note that, due to lower CO conversion in the WGS reactor (as a result of bypassing a part of synthesis gas flow around the WGS reactor), less heat is liberated in the exothermic WGS reaction. Consequently, only LP 
steam can be generated downstream of the WGS unit (see Figure 44) for the lower WGS reactor outlet temperatures.

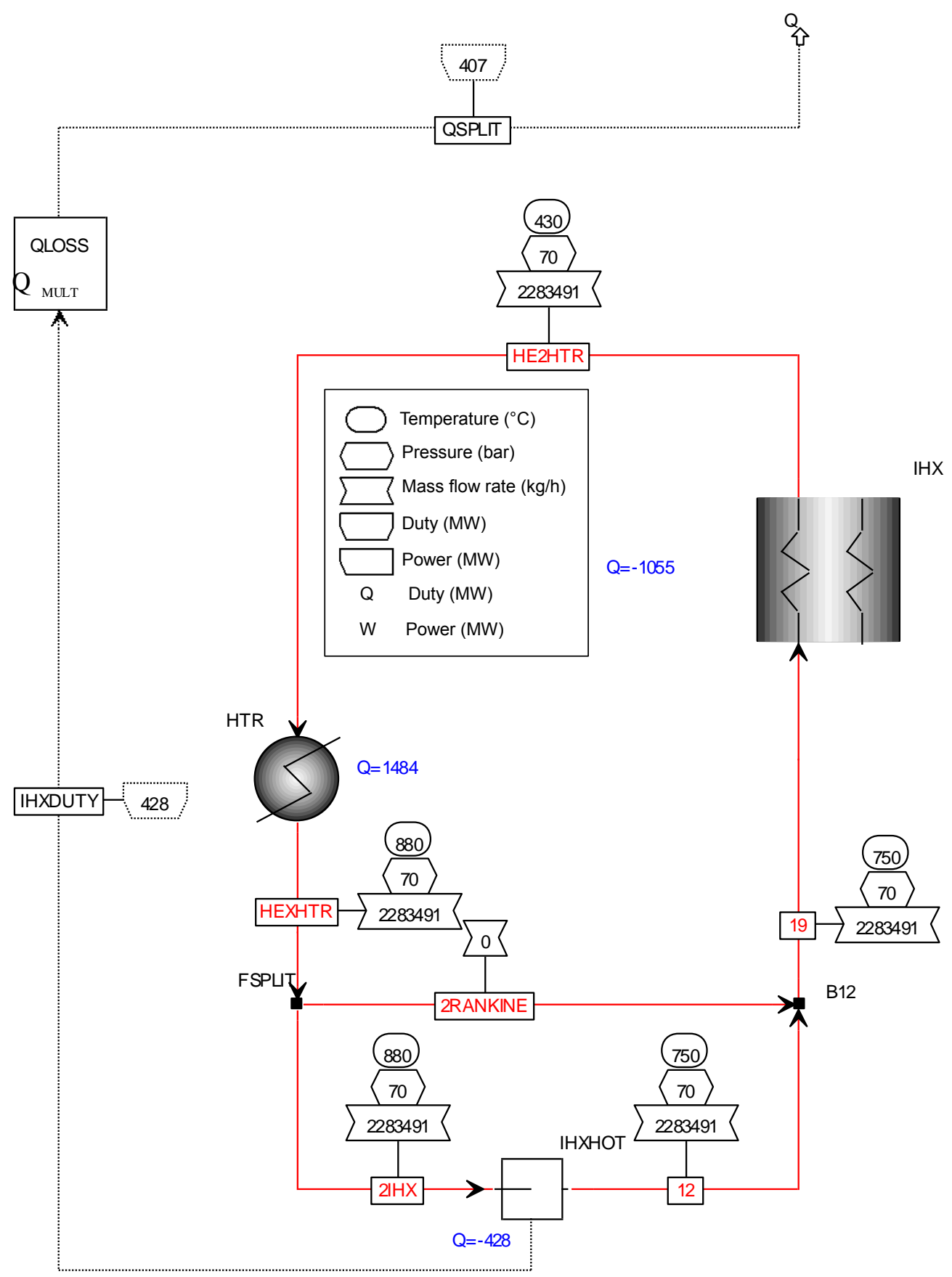

Figure 43: Modified process flow diagram for the cogeneration plant reactor outlet temperature dependence study with HTR outlet temperature of $880^{\circ} \mathrm{C}$. Note that no helium bypasses the hot intermediate heat exchanger for this study. 


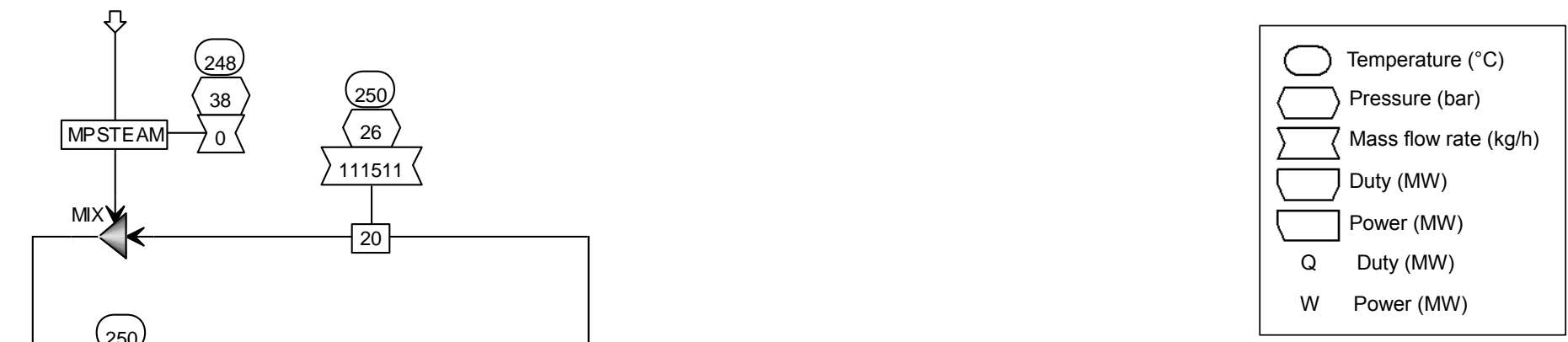

$\mathrm{Q}=0$
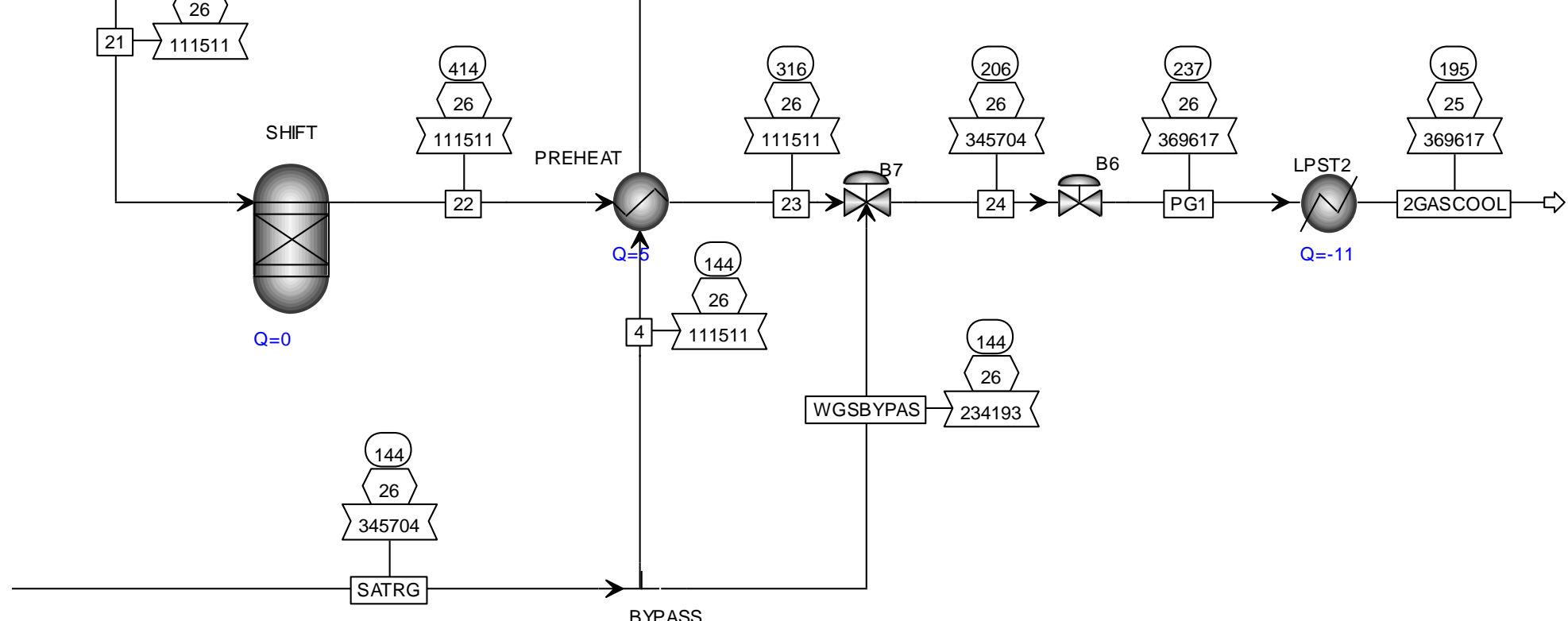

Figure 44: Modified process flow diagram for cogeneration plant reactor outlet temperature dependence study, showing the WGS reactor bypass stream. The process conditions shown resulted at an HTR outlet temperature of $880^{\circ} \mathrm{C}$. 
The effect of the reactor outlet temperature on the thermal efficiency, carbon utilisation, oxygen production and electricity production of the cogeneration plant is shown in Figure 45. As expected, the excess oxygen production increases at higher HTR outlet temperatures. This results in higher hydrogen production rates and therefore lower $\mathrm{CO}_{2}$ fractions in the product gas due to lower $\mathrm{CO}$ conversion (and thus $\mathrm{CO}_{2}$ production) in the WGS unit. Throughout, an $\mathrm{H}_{2} / \mathrm{CO}$ ratio of 2 was maintained in the product gas, as required by the downstream Fischer Tropsch synthesis process. According to the simulation results, $92.1 \%$ of the carbon feed to the plant ends up in the product gas (in the form of $\mathrm{CO}$ ) if the HTR outlet temperature is raised to $890^{\circ} \mathrm{C}$. At an HTR outlet temperature of $900^{\circ} \mathrm{C}$, the WGS unit is totally bypassed and not enough $\mathrm{CO}_{2}$ is available for the gasifier coal feeding system. It was therefore assumed that the highest feasible HTR outlet temperature for this study was $890^{\circ} \mathrm{C}$, although the carbon utilisation can be improved even further if another source of $\mathrm{CO}_{2}$ is available.

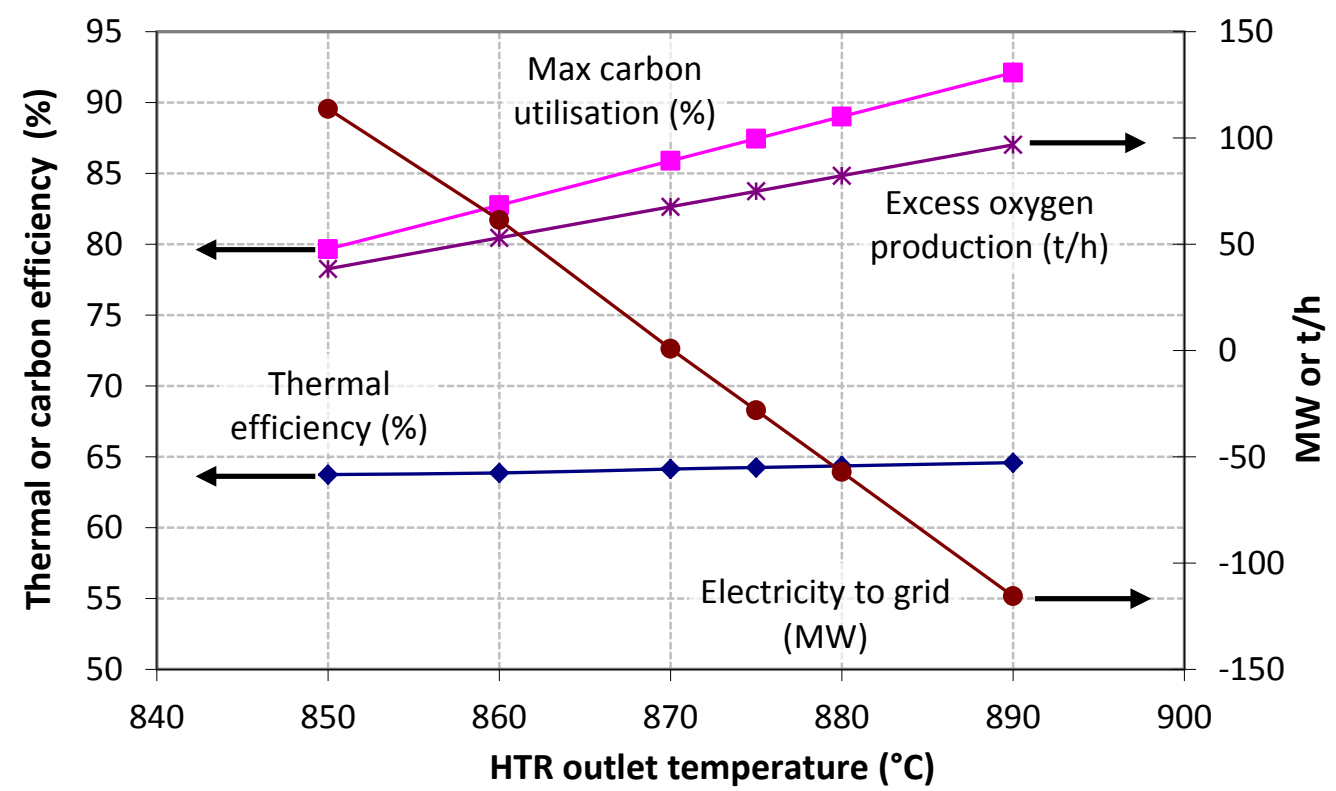

Figure 45: Economic yield criteria as a function of reactor outlet temperature for the cogeneration plant

The thermal efficiency of the plant was calculated using equation 4-1. It is interesting to note that the thermal efficiency of the plant is fairly stable between $64 \%$ and $65 \%$, although it increases slightly at higher HTR outlet temperatures. The calculations confirm that the decrease in thermal efficiency due to lower electricity production is compensated for by additional syngas production. This trend follows the Carnot principle, with an increase in overall plant thermal efficiency as the heat addition temperature of the HTR increases relative to the environmental temperature. Note that oxygen is not a fuel, but only supports combustion and therefore has no calorific value. For this reason, the additional oxygen production does not contribute to the thermal efficiency 
of the plant. The electricity demand and production was calculated as before. However, the combined electricity demand from the plant users and the electrolysis unit started exceeding the electricity supply from the Rankine cycle at an HTR outlet temperature of about $870^{\circ} \mathrm{C}$. If additional electricity was required for the cogeneration plant users, it was assumed that electricity could be imported from the grid at current Eskom electricity tariffs.

A simple economic analysis was performed in order to determine the optimum HTR outlet temperature from a profitability point of view. The difference in production values for electricity, oxygen, syngas and $\mathrm{CO}_{2}$ was calculated and compared to a base case. The base case was defined as the operating point where the hot intermediate heat exchanger's heat duty only meets the gasifier's oxygen demand. In all other cases in the sensitivity study, the oxygen production was maximised, using all the available HTR thermal energy above $800{ }^{\circ} \mathrm{C}$ to split water in the HTE unit. It was assumed that the relevant equipment (intermediate heat exchanger and water splitting units, etc.) could accommodate the additional production loads. The values of the relevant commodities are given in Table 22.

Table 22: Estimates of the values of cogeneration production variables

\begin{tabular}{|l|l|l|l|l|l|}
\hline Exchange rates & 8 & $\mathrm{R} / \$$ & 10.8 & $\mathrm{R} / €$ & Reference \\
\hline Electricity price & 0.523 & $\mathrm{R} / \mathrm{kWh}$ & 523 & $\mathrm{R} / \mathrm{MWh}$ & $\begin{array}{l}\text { Eskom, 2011 } \\
\text { [S.a.] }\end{array}$ \\
\hline Value of oxygen & 30 & $\mathrm{US} \$ / \mathrm{t}$ & 240 & $\mathrm{R} / \mathrm{t}$ & $\begin{array}{l}\text { Rameshni, 2002 } \\
\text { [S.a.] }\end{array}$ \\
\hline Carbon tax & 25 & $\mathrm{US} \$ / \mathrm{t} \mathrm{CO}_{2}$ & 200 & $\mathrm{R} / \mathrm{t} \mathrm{CO} 2$ & $\begin{array}{l}\text { Mantripragada et } \\
\text { al., 2011 }\end{array}$ \\
\hline Syngas value & 120 & $€ / \mathrm{km}^{3}{ }_{n}$ & 1296 & $\mathrm{R} / \mathrm{km}^{3}{ }_{\mathrm{n}}$ & $\begin{array}{l}\text { Trippe et al., } \\
\text { 2011: Case8 }\end{array}$ \\
\hline
\end{tabular}

The difference in income or expenses were calculated for the production variables listed in Table 22 at each HTR outlet temperature. The net income was determined by subtracting all operating costs from the total income. A plot of these results are displayed in Figure 46. Although the accuracy of the commodity prices (as listed in Table 22) may vary for different regions and scenarios, the results clearly illustrate the trade-offs for an electricity and syngas cogeneration plant. It can be seen that, for the assumed commodity values, the high values of syngas and electricity will balance each other quite well, while the income from additional oxygen production and the expected carbon tax avoidance plays a relative small role in the difference in net income of the plant. In this case, the value of the additional syngas, added to the extra oxygen and carbon tax saving, slightly outweighs the cost of imported electricity and results in a small increase in revenue at higher HTR outlet temperatures. However, this situation may change in periods of peak electricity usage (with higher electricity prices), favouring more electricity production. Mantripragada et al. (2011) found that the cost of liquid product 
from a CTL and electricity co-production plant decreased rapidly with increasing electricity prices. With the expected increase in electricity prices due to future carbon constraints, the financial risk of a syngas plant can thus be reduced by electricity and syngas co-production.

The sensitivity study assumed that all equipment could accommodate higher HTR outlet temperatures and higher production rates of hydrogen, oxygen and syngas, although this may require additional capital expenditure on equipment. These capital costs may influence the financial viability of the cogeneration plant negatively. In addition, increased maintenance costs at higher HTR outlet temperatures may also influence the business case adversely. The results of this sensitivity study therefore are an indication of possible economic considerations in the final design of an electricity and syngas cogeneration plant. However, these important questions can only be addressed in a more advanced design stage of the project, as recommended by Gandrik et al. (2011).

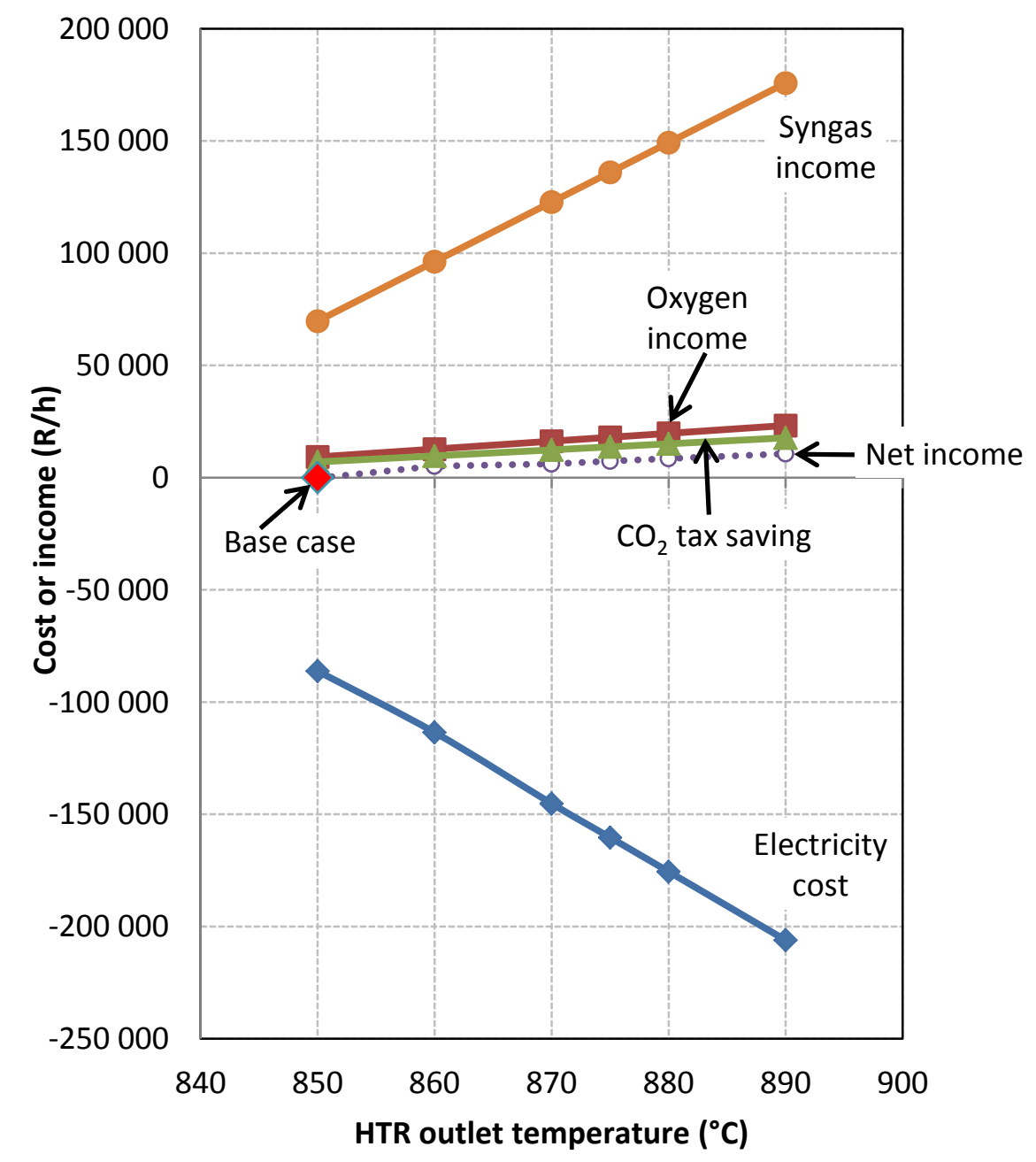

Figure 46: Analysis of the variable costs involved in the cogeneration plant reactor outlet temperature dependence study 


\section{Conclusions and recommendations}

The investigation into the viability of an HTR assisted coal gasification process illustrated the compelling case for the integration of HTR technology with a coal gasification process. It is predicted that an HTR coal gasification process will be feasible in the near future, provided that current technology development programs can demonstrate the viability of HTR and high temperature water splitting technology. The investigation generated a possible flow scheme for the process, based on an investigation of available technologies. The HTR coal gasification process was simulated successfully in Aspen Plus ${ }^{\circledR}(2009)$ and the model was used to perform various studies on the performance of the plant. The following main conclusions were made:

- The syngas production efficiency of the proposed cogeneration plant, based on the lower heating values of products and reactants, is $63.1 \%$. This figure compares very well to similar studies by Harvego et al. (2008), which yielded a syngas production efficiency of around $65 \%$. The results were also compared to a base case, which only included mature technologies, namely low temperature electrolysis technology and an HTR with an outlet temperature of $750{ }^{\circ} \mathrm{C}$, coupled to a Rankine steam cycle for power conversion. The syngas production efficiency is significantly higher than the base case value of $54.6 \%$. The higher efficiency can mainly be attributed to the higher thermal to hydrogen efficiency of the high temperature electrolysis process compared to the low temperature electrolysis process. Note that in the debate around the safety issues of HTR's, a reactor outlet temperature of $750{ }^{\circ} \mathrm{C}$ is seen as proven technology and also the reason why the Chinese HTRPM project aims to demonstrate its HTR concept at this reactor outlet temperature.

- The nuclear assisted syngas from coal concept yielded a carbon utilisation in excess of $71.5 \%$. This is an extremely good result, compared to a traditional process in which only about a third of the carbon ends up in the product. The cogeneration plant's calculated carbon utilisation of $71.5 \%$ is substantially lower than the figure of around $90 \%$ of the INL study (refer to Figure 39). The difference is due to the fact that all the HTR thermal energy is dedicated to syngas production in the INL study, whereas the current study only utilised a part of the HTR energy for hydrogen (and syngas) production and aimed to meet the gasifier's oxygen demand instead. However, if all the electricity of the Rankine cycle is used for hydrogen (and syngas) production (as discussed in section 4.4), the carbon utilisation increases to about $86 \%$ (refer to Figure 45), which corresponds well to the approximately $90 \%$ carbon utilisation of the INL study 
(Harvego et al., 2008). The improvement of carbon utilisation is attributed to the following:

- Carbon emissions from the coal fired power and steam plant is eliminated by replacing it with nuclear power.

- In addition, approximately $20 \%$ reduction in the mole fraction of $\mathrm{CO}_{2}$ in the synthesis gas is achieved, compared to a traditional fixed-bed-dry-bottom gasification process. This reduction is accomplished by adding hydrogen to the syngas downstream of the WGS unit. The required $\mathrm{H}_{2} / \mathrm{CO}$ ratio for the Fischer Tropsch process is 2, which means that less $\mathrm{CO}$ needs to be converted to $\mathrm{CO}_{2}$ to produce hydrogen in the WGS reaction.

- If enough hydrogen is available, the $\mathrm{CO}_{2}$ in the syngas product can be lowered to approximately $2 \%$. However, due to the energy intensive water splitting process, $\mathrm{CO}_{2}$ reduction will be achieved at a energy and cost penalty. The extent of the water-gas-shift reaction can be controlled to reduce the hydrogen requirement, although at a $\mathrm{CO}_{2}$ generation penalty.

- The optimum HTR outlet temperature for the nuclear assisted coal gasification process was found to be $850{ }^{\circ} \mathrm{C}$, which corresponds to the maximum exergy efficiency of the process. $850{ }^{\circ} \mathrm{C}$ is the minimum temperature at which the steam electrolysis hydrogen production section's operating temperature of $800{ }^{\circ} \mathrm{C}$ could be maintained, if a $25{ }^{\circ} \mathrm{C}$ temperature drop over each of the two intermediate heat exchangers is assumed. This conclusion matches that of a recent study by INL, that found the optimum HTR outlet temperature for the production of high temperature steam for electrolysis and hydrogen production to be $850{ }^{\circ} \mathrm{C}$ (Gandrik et al., 2011).

- Nuclear assisted syngas from coal can be designed to meet flexible energy demands by varying hydrogen, syngas and electricity production ratios. The most profitable operating regime will be influenced by the value of cogeneration plant products. However, due to time constraints, the study did not include a detailed economic analysis of the proposed process.

All the cogeneration plant sections were validated with data from literature or fundamental models, as discussed previously. The overall simulation model results confirm the accuracy of the simulation method.

The detailed simulation of the acid gas removal unit downstream of the water gas shift unit was not part of the scope of the project due to time constraints. It was assumed that the $\mathrm{CO}_{2}$ from the acid gas removal unit was freely available for use as a coal transport gas in the gasification section, but in reality the electricity consumption within the acid gas removal unit will lower the syngas production efficiency slightly. 


\section{Recommendations:}

- Further development and demonstration of specific technology components within the HTR assisted coal gasification concept are still required, including the intermediate heat exchanger, the hydrogen production plant, as well as high temperature gas reactor technology.

- The intermediate heat exchanger is susceptible to diffusion of radioactive hydrogen and tritium between the primary and secondary loops at very high temperatures. Consequently, radioactive material might end up in product streams if HTR technology is applied for industrial process heat applications. Currently, additional heat transfer loops and heat exchangers are required to provide a barrier against tritium migration. Unfortunately, additional heat transfer loops will result in severe exergy and thermal efficiency losses, as well as in extra capital costs. Heat transfer concepts for the intermediate heat exchanger was previously suggested by the HTR consortiums (see Table 3), but lacks operational experience and will need to be developed further before HTR technology will be ready for implementation in process heat applications. A promising heat pipe type heat exchanger concept was suggested by Dobson (2011), which may provide an effective barrier against radioactive hydrogen and tritium diffusion through the intermediate heat exchanger. It is recommended that this concept should be investigated in more detail.

- The optimal HTR outlet temperature of $850{ }^{\circ} \mathrm{C}$ was based on thermodynamic considerations. However, it is recommended that a detailed economic analysis should be performed to determine the optimum HTR outlet temperature more accurately. The economic analysis should include the effect of HTR outlet temperature on HTR size and configuration as well as operating and maintenance cost.

- In a typical gasification plant, nitrogen is used as utility air due to its inert characteristics and the fact that it is available from the air separation unit. In the absence of an air separation unit, an alternative source of nitrogen should be provided. Alternatively, the viability of using $\mathrm{CO}_{2}$ as a utility inert gas instead of $\mathrm{N}_{2}$ should be investigated.

- Although steam generation in the syngas cooler of the Shell Coal Gasification Process produces steam at around $560{ }^{\circ} \mathrm{C}$ in most commercial applications, it was assumed that this steam could be superheated to $800{ }^{\circ} \mathrm{C}$ for use in the high temperature electrolysis unit. The feasibility of the design of the superheater should be investigated in more detail, specifically possible issues regarding materials suitable for these high temperatures. 


\section{References}

Aspen Plus ${ }^{\circledR}$ V7.1 2009. Aspen Technology

Bilir, Ö. 2010. ExerCom v2.2 manual. Jacobs Consulting. Correspondence. May 2011.

Çengel, Y.A. \& Boles, M.A. 2011. Thermodynamics. $7^{\text {th }}$ edition. New York: McGraw-Hill.

Centralized hydrogen production from nuclear power: infrastructure analysis and test-case design study. 2006. U.S. Department of Energy Office of Nuclear Energy Science and Technology Nuclear Energy Research Initiative (NERI).

Choi, Y. \& Stenger, H.G. 2003. Water gas shift reaction kinetics and reactor modeling for fuel cell grade hydrogen Journal of Power Sources 124: 432 - 439.

Dobson, R.T. 2011. Personal interview. 23 November 2011, Stellenbosch.

Eberhard, A. 2011. The future of South African Coal: Market, Investment, and policy challenges. Working Paper \# 100. Program on Energy and Sustainable Development. Stanford University. [Online]. Available: http://iisdb.stanford.edu/pubs/23082/WP 100 Eberhard Future of South Afric an Coal.pdf [2011, November 04]

Elder R. \& Allen R. 2009. Nuclear heat for hydrogen production: Coupling a very high/high temperature reactor to a hydrogen production plant. Progress in Nuclear Energy 51: 500 - 525.

Engels, H., Funk, J.E., Hesselmann, K. \& Knoche, K. 1987. Thermochemical hydrogen production. International Journal of Hydrogen Energy 5: 291 - 295.

Eskom's 2011/12 tariffs and charges for large power users excluding local authorities. [S.a.]. [Online].

Available: http://www.eskom.co.za/content/441931\%20lssue\%201\%20LPU\%20\%20vasu.pdf [2011, December 6]

Ewan, B.C. \& Allen, R.W.K. 2005. A figure of merit assessment of the routes to hydrogen. International Journal of Hydrogen Energy 30: 809819.

Fogler, H.S. 2006. Elements of Chemical Reaction Engineering. $4^{\text {th }}$ edition. Upper Saddle River, New Jersey: Pearson Education. 
Forsberg, C.W. 2007. Future hydrogen markets for large-scale hydrogen production systems. International Journal of Hydrogen Energy 32: 431 439.

Fröhling, W., Unger, H. \& Dong, Y. 2002. Thermodynamic assessment of plant efficiencies for HTR power conversion systems. 1st International Topical Meeting on HTR Technology. Petten, The Netherlands.

Fujiwara S., Kasai, S., Yamauchi, H., Yamada, K., Makino, S., Matsunaga, K., Yoshino, M., Kameda, T., Ogawa, T., Momma, S. \& Hoashi, E. 2008. Hydrogen production by high temperature electrolysis with nuclear reactor, Progress in Nuclear Energy 50: 422 - 426.

Gandrik, A, McKellar, M, O Nelson, L, Patterson, M, Robertson, E \& Wood, R. 2011. Optimum Reactor Outlet Temperatures for High Temperature Gas-Cooled Reactors Integrated with Industrial Processes. Idaho National Laboratory Next Generation Nuclear Plant Project. Report \# INL/EXT-11-21537. [Online].

Available:https://inlportal.inl.gov/portal/server.pt/document/84003/optimu $\mathrm{m}$ reactor outlet temperatures for high temperature gascooled reactors integrated with industrial processes pdf [2011, November 28].

Gomez A., et al. 2007. Optimization of electricity/hydrogen cogeneration from generation IV nuclear energy systems, $17^{\text {th }}$ European Symposium on Computer Aided Process Engineering. Elsevier.

Greyvenstein, R., Correia, M. \& Kriel, W. 2008. South Africa's opportunity to maximise the role of nuclear power in a global hydrogen economy, Nuclear Engineering and Design 238 :3031 - 3040.

Harvego, E.A., McKellar, M.G. \& O'Brien, J.E. 2008. System analysis of nuclear-assisted syngas production from coal. Proceedings of the 4th International Topical Meeting on High Temperature Reactor Technology. Washington. 28 September - 1 October.

Higman, C. \& Van der Burgt, M. 2003. Gasification. Burlington: Gulf Professional Publishing.

IAEA, 1999. Hydrogen as an energy carrier and its production by nuclear power. IAEA-TECDOC-1085.

IEA, 2009. Key World Energy Statistics 2009.

IEA, 2010. Key World Energy Statistics 2010.

Jeong, Y.H., Hohnholt, K.J., Yildiz, B. \& Kazimi, M.S. 2005. Optimization of the hybrid sulfur cycle for hydrogen generation. ICAPP '05. Seoul, Korea. 
Kanoglu, M.\& Dincer, I. 2008. Performance assessment of cogeneration plants. Energy Conversion and Management 50: 76 - 81.

Kelly D. 2009. PBMR's new value proposition with expanded scope of application. Mechanical Technology, September 2009: 20 - 27.

Kruger J.-H. \& Du Toit, C.G. 2006. The simulation of a thermal-fluid system using an integrated systems CFD approach. Fifth International Conference on CFD in the Process Industries. CSIRO, Melbourne, Australia. 13 - 15 December.

Kubo, S., Kasahara, S., Okuda, H., Terada, A., Tanaka, N., Inaba, Y., Ohashi, H., Inagaki, Y., Onuki, K. \& Hino, R. 2004. A pilot test plan of the thermochemical water-splitting iodine-sulfur process. Nuclear Engineering and Design 233: 355 - 362.

Lahoda, E.J., McLaughlin, D.F., Mulik, R., Kriel,W., Kuhr, R., Bolthrunis C. \& Corbett, M. 2006. Estimated costs for the improved HyS flowsheet. Proceedings of the Third International Topical Meeting on High Temperature Reactor Technology. Johannesburg. October 1 - 4.

Larminie, J. \& Dicks, A. 2003. Fuel Cell Systems Explained. $2^{\text {nd }}$ edition. Chisester: John Wiley \& Sons.

Mantripragada, H.C. \& Rubin, E.S. 2011. Techno-economic evaluation of coal-to-liquids (CTL) plants with carbon capture and sequestration, Energy Policy 39.5: 2808 - 2816.

Miller, A.I. \& Duffey, R.B. 2005. Sustainable and economic hydrogen production from nuclear energy in competitive power markets. Energy 30: 2690 - 2702.

NIST data. [S.a.]. [Online]. Available: http://kinetics.nist.gov/janaf/ [2011, November 23].

NEL Hydrogen atmospheric electrolyser technical data. [S.a.]. [Online]. Available: http://www.nel-hydrogen.com/home/?pid=75 [2011, December 1]

O'Brien, J.E. 2008. Thermodynamic Considerations for Thermal Water Splitting Processes and High-Temperature Electrolysis. 2008 ASME International Congress and Exposition. Boston. 31 October -6 November.

Perrot, P. 1998. A to Z of Thermodynamics. Cary, North Carolina: Oxford University Press.

Perry, R.H. \& Green D.W. 2008. Perry's Chemical Engineers' Handbook. 8th edition. New York: McGraw-Hill. 
Potential for Improvement in Gasification Combined Cycle Power Generation with $\mathrm{CO}_{2}$ Capture. 2003. IEA Greenhouse Gas R\&D Programme Report PH4/19.

Rameshni, M. 2002. Cost effective options to expand SRU capacity using oxygen. Sulfur Recovery Symposium Brimstone Engineering Services. Calgary, Canada. 6 - 10 May. [S.a.]. [Online]. Available: http://www.worleyparsons.com/CSG/Hydrocarbons/SpecialtyCapabilities IDocuments/Cost Effective Options to Expand SRU Capacity Using Oxygen.pdf [2010, December 8].

Rankine cycle. [S.a.]. [Online]. Available: http://en.wikipedia.org/wiki/Rankine cycle [2010, December 8].

Rant, Z. 1956. Exergy, a New Word for "Technical Available Work" (in German), Forsch. Ing. Wes. 22.1: 36 - 37.

Rezvani, S., Huang, Y., Mcllveen-Wright, D., Hewitt, N. \& Wang, Y. 2007. Comparative assessment of sub-critical versus advanced super-critical oxyfuel fired PF boilers with $\mathrm{CO}_{2}$ sequestration facilities. Fuel 86.14: $2134-2143$.

Sasol Annual Review 2010 [Online]. Available: http://sasol.investoreports.com/sasol review 2010/operatingreviews/sasol-synfuels/ [2012, March 16].

Sasol's $\mathrm{CO}_{2}$ emissions down. [Online]. Available: http://www.news24.com/SciTech/News/Sasols-CO2emissions-down-20091120 [2012, March 16].

Sasol's unique coal-to liquids technology [S.a.]. [Online]. Available: http://www.sasol.com/sasol internet/downloads/CTL Brochure 1125921 891488.pdf [2012, March 16].

Singh, O. 2006. Engineering Thermodynamics. New Delhi: New Age International $(P)$ Ltd. Publishers.

Small Nuclear Power Reactors. [S.a.]. [Online]. Available: http://www.worldnuclear.org/info/default.aspx?id=534\&terms=htr-pm [2012, March 16].

Stern, N., 2007. The Economics of Climate Change: The Stern Review. London: Cambridge University Press.

Szargut, J., Morris, D.R. \& Steward, F.R. 1998. Exergy analysis of thermal, chemical, and metallurgical processes New York: Hemisphere Publishing Corporation. 
Trippe, F., Fröhling, M., Schultmann, F., Stahl, R. \& Henrich, E. Technoeconomic assessment of gasification as a process step within biomassto-liquid (BtL) fuel and chemicals production. Fuel Processing Technology 92.11: 2169 - 2184.

United Kingdom Department of Environment Food and Rural Affairs. 2008. Climate change bill. Bill 97.

Yildiz, B. \& Kazimi, M.S. 2006. Efficiency of hydrogen production systems using alternative nuclear energy technologies. International Journal of Hydrogen Energy 31: 77 - 92.

Zhang, Z., Wu, Z., Wang, D., Xu, Y., Sun, Y., Li, F., Dong, Y. 2009. Current status and technical description of Chinese 2x250 MWth HTR-PM demonstration plant. Nuclear Engineering and Design 239.7: 1212 1219.

Zhang, Z., Wu, Z., Sun, Y. \& Li, F. 2006. Design aspects of the Chinese modular high-temperature gas-cooled reactor HTR-PM. Nuclear Engineering and Design 236.5 - 6: 485 - 490. 


\section{APPENDIX A: Calculation of Gasification Unit Simulation Parameters}

The following method was followed to calculate the input values for the entrained flow gasifier model:

\section{A.1 Calculation of gasifier yield}

\section{Assumed DRY gasifier yield}

The entrained flow gasifier yield was based on Table A-2 for South African coal. Note that the yield corresponds very well with the dry raw product gas yield with $\mathrm{N}_{2}$ feed as reported in Table A-3. However, the $\mathrm{N}_{2}$, Ar and $\mathrm{H}_{2} \mathrm{~S}$ yields of Table A-2 were reduced by $0.1 \%$ points to reduce the total mol $\%$ to $100 \%$. It was therefore assumed that gasifier yields the following dry raw product gas ( in mol \%), with $\mathrm{N}_{2}$ as coal transport medium:

\begin{tabular}{|l|c|}
\hline $\mathrm{CO}_{2}$ & $1.0 \%$ \\
\hline $\mathrm{CO}$ & $64.0 \%$ \\
\hline $\mathrm{H}_{2}$ & $33.0 \%$ \\
\hline $\mathrm{N}_{2}$ & $0.9 \%$ \\
\hline $\mathrm{Ar}$ & $0.9 \%$ \\
\hline $\mathrm{H}_{2} \mathrm{~S}$ & $0.2 \%$ \\
\hline \multicolumn{3}{|c|}{$\mathbf{1 0 0 \%}$} \\
\hline
\end{tabular}

\section{Assumed WET gasifier yield}

The wet raw product gas includes 1.9 mol \% water according to Table A-3 (see $\mathrm{N}_{2}$ feed at 30 bar with $99 \% \mathrm{O}_{2}$ feed). The assumed dry raw product gas was normalised to include the steam in the raw gas, which yielded the following wet gasifier yield:

\begin{tabular}{|c|c|}
\hline $\mathrm{H}_{2} \mathrm{O}$ & $1.90 \%$ \\
\hline $\mathrm{CO}_{2}$ & $0.98 \%$ \\
\hline $\mathrm{CO}$ & $62.78 \%$ \\
\hline $\mathrm{H}_{2}$ & $32.37 \%$ \\
\hline $\mathrm{N}_{2}$ & $0.88 \%$ \\
\hline $\mathrm{Ar}$ & $0.88 \%$ \\
\hline $\mathrm{H}_{2} \mathrm{~S}$ & $0.20 \%$ \\
\hline
\end{tabular}

\section{Simulate gasifier in Aspen Plus ${ }^{\circledR}$ (2009)}

A gasifier simulation was developed in Aspen Plus ${ }^{\circledR}$ (2009), making use of the "RYield" reactor simulation block. This model simulates a reactor by specifying the reactor yields of each component. This model is useful when the reaction 
stoichiometry and kinetics are unknown and when reactor yield distribution data are available. The inerts in the feed is specified and the "RYield"-model normalises the known yields to maintain a mass balance.

\section{Tune model to match theoretical gasifier yield}

According to Table A-2, the pure gas yield per tonne moisture and ash free (maf) coal for typical South African coal in an entrained flow gasifier, is 2070 $\mathrm{m}_{\mathrm{n}}^{3}\left(\mathrm{CO}+\mathrm{H}_{2}\right)$ per tonne maf coal. The Aspen Plus ${ }^{\circledR}(2009)$ gasifier model calculated a slightly higher value, which can probably be attributed to heat losses in an actual gasifier, as well as small process inefficiencies typically encountered in an actual gasifier. In order to match the simulation results with the theoretical value, a "losses" stream was created to reduce the pure gas yield to $2070 \mathrm{~m}^{3}{ }_{\mathrm{n}}\left(\mathrm{CO}+\mathrm{H}_{2}\right)$ per tonne maf coal. The "losses" stream was extracted from the gasifier outlet stream. It was found that a split fraction of $3.6 \%$ of the raw gas output yielded an accurate pure gas yield value. This implies that the Aspen Plus ${ }^{\circledR}$ (2009) gasifier model yields $3.6 \%$ too much pure gas per tonne maf coal.

\section{Replace $\mathrm{N}_{2}$ with $\mathrm{CO}_{2}$ as coal transport medium}

In the next step, $\mathrm{CO}_{2}$ was used to replace nitrogen as the coal transport gas. The following dry wet product gas gasifier yield was assumed, based on the values reported in Table A-3 (see $\mathrm{CO}_{2}$ feed at 30 bar with $99 \% \mathrm{O}_{2}$ feed). Note that the $\mathrm{CO}_{2}$ yield increases only slightly with $1 \mathrm{~mol} \%$ to $2 \mathrm{~mol} \%$. It was assumed that the $0.9 \mathrm{~mol} \%$ for $\mathrm{N}_{2}+$ Ar could be distributed equally between the two gasses, which resulted in a yield of $0.45 \mathrm{~mol} \%$ for each. The assumed wet raw product gas was the following:

\begin{tabular}{|l|c|}
\hline $\mathrm{CO}_{2}$ & $2.00 \%$ \\
\hline $\mathrm{CO}$ & $64.47 \%$ \\
\hline $\mathrm{H}_{2}$ & $31.94 \%$ \\
\hline $\mathrm{N}_{2}$ & $0.45 \%$ \\
\hline $\mathrm{Ar}$ & $0.45 \%$ \\
\hline $\mathrm{H}_{2} \mathrm{~S}$ & $0.30 \%$ \\
\hline $\mathrm{H}_{2} \mathrm{O}$ & $0.2 \%$ \\
\hline $\mathrm{CH}_{4}$ & $0.2 \%$ \\
\hline \multicolumn{2}{|c|}{} \\
\multicolumn{1}{|c|}{} & $100.0 \%$ \\
\hline
\end{tabular}

\section{Update Aspen Plus ${ }^{\circledR}$ (2009) model with assumed yield}

Lastly, the assumed wet raw product gas values was updated in the Aspen Plus $®$ (2009) gasifier model - see Figure 17 for a snapshot of the specification sheet of this model. Note that it was assumed that the fraction of pure gas yield loss, as represented by the "losses" stream, remained at the same value as previously determined. 
Table A-1: Analysis of various coals (Higman et al., 2003:46)

\begin{tabular}{|c|c|c|c|c|c|c|c|c|c|c|c|c|}
\hline \multicolumn{3}{|c|}{ Coal } & \multicolumn{4}{|c|}{$\begin{array}{l}\text { Proximate Analysis } \\
\% \text { mass as received }\end{array}$} & \multicolumn{5}{|c|}{$\begin{array}{c}\text { Ultimate Analysis } \\
\% \text { mass on moisture and } \\
\text { ash free (maf) coal }\end{array}$} & \multirow{2}{*}{$\begin{array}{c}\begin{array}{c}\text { LHV } \\
\text { maf } \\
\text { coal }\end{array} \\
\text { MJ/kg }\end{array}$} \\
\hline Country & Region & Class & \begin{tabular}{|l|l} 
Fixed \\
carbon
\end{tabular} & $\begin{array}{l}\text { Volatile } \\
\text { matter }\end{array}$ & Water & Ash & C & $\mathbf{H}$ & 0 & $\mathbf{N}$ & $\mathbf{S}$ & \\
\hline Germany & Rhein & Browncoal & 17.3 & 20.0 & 60.0 & 2.7 & 67.5 & 5.0 & 26.5 & 0.5 & 0.5 & 26.2 \\
\hline U.S.A. & North Dakota & Lignite & 27.8 & 24.9 & 36.9 & 10.4 & 71.0 & 4.3 & 23.2 & 1.1 & 0.4 & 26.7 \\
\hline U.S.A. & Montana & Sub-bituminous & 43.6 & 34.7 & 10.5 & 11.2 & 76.4 & 5.6 & 14.9 & 1.7 & 1.4 & 31.8 \\
\hline U.S.A. & Illinois & Bituminous & 39.3 & 37.0 & 13.0 & 10.7 & 78.4 & 5.4 & 9.9 & 1.4 & 4.9 & 33.7 \\
\hline Poland & Typical & Bituminous & 54.9 & 35.6 & 5.3 & 4.2 & 82.8 & 5.1 & 10.1 & 1.4 & 0.6 & 36.1 \\
\hline South Africa & Typical & Bituminous & 51.3 & 32.7 & 2.2 & 13.8 & 83.8 & 4.8 & 8.4 & 2.0 & 1.0 & 34.0 \\
\hline China & Datung & Bituminous & 50.9 & 28.1 & 11.9 & 9.1 & 84.4 & 4.4 & 9.5 & 0.9 & 0.8 & 33.4 \\
\hline India & Typical & Bituminous & 30.0 & 23.0 & 7.0 & 40.0 & 75.5 & 6.4 & 15.2 & 1.5 & 1.4 & 32.1 \\
\hline Australia & Typical & Bituminous & 44.9 & 41.1 & 4.5 & 9.5 & 81.3 & 5.8 & 10.0 & 2.0 & 0.9 & 33.8 \\
\hline Germany & Ruhr & Anthracite & 81.8 & 7.7 & 4.5 & 6.0 & 91.8 & 3.6 & 2.5 & 1.4 & 0.7 & 36.2 \\
\hline
\end{tabular}


Table A-2: Performance of various types of coals in dry coal feed entrained-flow gasifiers (Higman et al., 2003:126)

\begin{tabular}{|c|c|c|c|c|c|c|c|c|c|c|c|}
\hline \multicolumn{3}{|c|}{ Coal } & \multicolumn{6}{|c|}{ Gas analysis of dry gas, mol \% } & \multirow{2}{*}{$\begin{array}{c}\text { Product yield } \\
\mathrm{m}_{\mathrm{n}}^{3}\left(\mathrm{CO}+\mathrm{H}_{2}\right) / \\
\text { tonne maf coal }\end{array}$} & \multirow{2}{*}{$\begin{array}{c}\begin{array}{c}\text { Oxygen } \\
\text { required }\end{array} \\
\mathrm{m}^{3}{ }_{n} \mathrm{O}_{2} l \\
\mathrm{~m}^{3}{ }_{\mathrm{n}}\left(\mathrm{CO}+\mathrm{H}_{2}\right)\end{array}$} & \multirow{2}{*}{$\begin{array}{c}\begin{array}{c}\text { Steam } \\
\text { required }\end{array} \\
\begin{array}{c}\mathbf{k g} \text { steam/ } \\
\mathrm{m}_{\mathrm{n}}^{3}\left(\mathrm{CO}+\mathrm{H}_{2}\right)\end{array}\end{array}$} \\
\hline Country & Region & Class & $\mathrm{CO}_{2}$ & CO & $\mathrm{H}_{2}$ & $\mathbf{N}_{2}$ & $\mathrm{Ar}$ & $\mathrm{H}_{2} \mathrm{~S}$ & & & \\
\hline Germany & Rhein & Browncoal & 8 & 61 & 29 & 1 & 1 & 0.2 & 965 & 0.33 & 0 \\
\hline U.S.A. & $\begin{array}{l}\text { North } \\
\text { Dakota }\end{array}$ & Lignite & 10 & 62 & 26 & 1 & 1 & 0.1 & 935 & 0.36 & 0 \\
\hline U.S.A. & Montana & $\begin{array}{l}\text { Sub- } \\
\text { bituminous }\end{array}$ & 1 & 63 & 34 & 1 & 1 & 0.4 & 1950 & 0.26 & 0.06 \\
\hline U.S.A. & Illinois & Bituminous & 1 & 61 & 35 & 1 & 1 & 1.5 & 2030 & 0.25 & 0.09 \\
\hline Poland & Typical & Bituminous & 1 & 58 & 39 & 1 & 1 & 0.2 & 2290 & 0.20 & 0.15 \\
\hline $\begin{array}{l}\text { South } \\
\text { Africa }\end{array}$ & Typical & Bituminous & 1 & 64 & 33 & 1 & 1 & 0.3 & 2070 & 0.26 & 0.09 \\
\hline China & Datung & Bituminous & 1 & 66 & 31 & 1 & 1 & 0.2 & 2060 & 0.27 & 0.09 \\
\hline India & Typical & Bituminous & 2 & 62 & 33 & 1 & 1 & 0.5 & 1730 & 0.31 & 0 \\
\hline Australia & Typical & Bituminous & 1 & 62 & 34 & 1 & 1 & 0.3 & 2100 & 0.26 & 0.07 \\
\hline Germany & Ruhr & Anthracite & 1 & 65 & 31 & 1 & 1 & 0.2 & 2270 & 0.26 & 0.13 \\
\hline
\end{tabular}


Table A-3: Influence of the coal transport gas on syngas composition (Adapted from Higman et al., 2003:176)

\begin{tabular}{|l|r|r|}
\hline Process & \multicolumn{2}{|c|}{ Single-stage dry feed } \\
\hline Operating temperature $\left({ }^{\circ} \mathrm{C}\right)$ & 1500 & 1500 \\
Operating pressure (bar a) & 30 & 30 \\
Coal transport medium & $\mathrm{CO}_{2}$ & $\mathrm{~N}_{2}$ \\
Cold gas efficiency $(\%)$ & 82 & 82 \\
Oxygen purity & $99 \%$ \\
\hline Wet raw product gas (mol \%) \\
\hline $\mathrm{CO}$ & 64.5 & 61.9 \\
$\mathrm{H}_{2}$ & 31.9 & 32.2 \\
$\mathrm{CO}_{2}$ & 2.0 & 1.0 \\
$\mathrm{H}_{2} \mathrm{O}$ & 0.2 & 1.9 \\
$\mathrm{CH}_{4}$ & 0.2 & 0 \\
$\mathrm{H}_{2} \mathrm{~S}$ & 0.3 & 0.3 \\
$\mathrm{~N}_{2}+\mathrm{Ar}$ & 0.9 & 2.7 \\
\hline $\mathrm{Dry}_{\text {raw product gas (mol \%) }}$ & \\
\hline $\mathrm{CO}^{2}$ & 64.6 & 63.2 \\
$\mathrm{H}_{2}$ & 32.0 & 32.8 \\
$\mathrm{CO}_{2}$ & 2.0 & 1.0 \\
$\mathrm{CH}_{4}$ & 0.2 & 0 \\
$\mathrm{H}_{2} \mathrm{~S}$ & 0.3 & 0.3 \\
$\mathrm{~N}_{2}+\mathrm{Ar}$ & 0.9 & 2.7 \\
$\mathrm{H}_{2} / \mathrm{CO}$ molar ratio & 0.5 & 0.52 \\
$\mathrm{CO}_{2} / \mathrm{H}_{2} \mathrm{~S}$ molar ratio & 7 & 3.3 \\
\hline
\end{tabular}




\section{A.2 Calculation of gasifier steam and oxygen requirements}

The entrained flow gasifier's oxygen and steam requirements were calculated based on the values reported for typical South African coal (Refer to Table A-2):

- $\mathrm{m}^{3}{ }_{\mathrm{n}}\left(\mathrm{CO}+\mathrm{H}_{2}\right) /$ tonne maf coal $=2070$

- $\mathrm{m}_{\mathrm{n}}^{3} \mathrm{O}_{2} / \mathrm{m}_{\mathrm{n}}^{3}\left(\mathrm{CO}+\mathrm{H}_{2}\right)=0.26$

$$
\begin{aligned}
& \text { thus, oxygen volume }=538.2 \quad \mathrm{~m}^{3} \mathrm{O}_{2} \\
& =24.01 \mathrm{kmol} \mathrm{O}{ }_{2} \\
& =\underline{768.4 \mathrm{~kg} \mathrm{O}} \underline{\mathrm{O}}_{2} \text { tonne maf coal }
\end{aligned}
$$

- $\mathrm{kg} \mathrm{steam} / \mathrm{m}^{3}{ }_{\mathrm{n}}\left(\mathrm{CO}+\mathrm{H}_{2}\right)=0.09$

thus, required steam $=\underline{186.3 \mathrm{~kg} \text { steam } / \text { tonne maf coal }}$

\section{A.3 Calculation of gasifier feed streams}

Ultimate analysis (Mass \%):

\begin{tabular}{|c|c|c|}
\hline Coal feed: & $\begin{array}{c}4000 \\
166666.7 \\
46.30\end{array}$ & $\begin{array}{l}\mathrm{t} / \mathrm{d} \\
\mathrm{kg} / \mathrm{h} \\
\mathrm{kg} / \mathrm{s}\end{array}$ \\
\hline Ash mass fraction & 0.138 & \\
\hline Moisture mass fraction & 0.022 & \\
\hline Ash in feed & 23000 & $\mathrm{~kg} / \mathrm{h}$ \\
\hline Moisture in feed & 3666.67 & $\mathrm{~kg} / \mathrm{h}$ \\
\hline Coal feed, maf & 140000 & $\mathrm{~kg} / \mathrm{h}$ \\
\hline $\mathrm{O}_{2}$ feed & 107572.3 & $\mathrm{~kg} / \mathrm{h}$ \\
\hline Steam feed & 26082 & $\mathrm{~kg} / \mathrm{h}$ \\
\hline
\end{tabular}

(Refer to Table A-1)

\begin{tabular}{|l|c|c|}
\multicolumn{1}{c}{} & Mass \% on maf coal & Dry with ash \\
\hline Carbon & 83.8 & 72.2 \\
\hline Hydrogen & 4.8 & 4.1 \\
\hline Nitrogen & 2 & 1.7 \\
\hline Combustible sulphur & 1 & 0.9 \\
\hline Oxygen (balance) & 8.4 & 7.2 \\
\hline Ash & 0 & 13.8 \\
\hline \multicolumn{2}{|c|}{} & $100 \%$ \\
\hline
\end{tabular}




\section{A.4 Calculation of coal transport medium feed stream}

The use of different gasses as coal transport medium is discussed in detail in literature and will not be repeated in this text. (Refer to Higman et al., 2003:171-177). The following assumptions and method was used to determine the required $\mathrm{CO}_{2}$ transport gas flow rate:

\section{ASSUMPTIONS}

1. Assume dry-coal feeding with lock hoppers

2. $\mathrm{CO}_{2}$ for sequestration available for acid gas removal system

3. $\mathrm{CO}_{2}$ fed at 35 bar, $76{ }^{\circ} \mathrm{C}$

4. Gasifier yield as reported in Table A-3 for $\mathrm{CO}_{2}$ feed at 30 bar with $99 \% \mathrm{O}_{2}$ feed

5. Coal loading of $300 \mathrm{~kg} /$ actual $\mathrm{m}^{3}$ required. (Higman et al.,2003:175)

Note that it is assumed that this figure is fixed, irrespective of the gas used.

\begin{tabular}{|l|c|l|}
\hline CONSTANTS & & \\
\hline $\mathrm{CO}_{2}$ molar mass & 44.01 & $\mathrm{~kg} / \mathrm{kmol}$ \\
\hline $\mathrm{R}$, gas constant & 8.31447 & $\mathrm{kPa} \cdot \mathrm{m}^{3} / \mathrm{kmol} . \mathrm{K}$ \\
\hline \multicolumn{3}{|l|}{} \\
\hline INPUTS & & \\
\hline $\mathrm{CO}_{2}$ feed pressure & 35.0 & $\mathrm{bar}$ \\
\hline $\mathrm{CO}_{2}$ feed temperature & 76.0 & ${ }^{\circ} \mathrm{C}$ \\
\hline Coal loading & 300 & $\mathrm{~kg} \mathrm{coal} / \mathrm{m}^{3}$ gas \\
\hline Gasifier capacity & 4000 & tonne coal $/ \mathrm{day}$ \\
\hline \multicolumn{2}{|l|}{} \\
\hline OUTPUTS & 1.206 & $\mathrm{kmol}$ \\
\hline Moles $\mathrm{CO}_{2}$ required & 53.06 & $\mathrm{~kg}$ \\
\hline Mass $\mathrm{CO}_{2}$ required & 0.177 & $\mathrm{~kg} \mathrm{CO} / / \mathrm{kg}$ coal \\
\hline Mass $\mathrm{CO}_{2}$ required & 166666.7 & $\mathrm{~kg} / \mathrm{h}$ \\
\hline Coal feeding rate & 29478.15 & $\mathrm{~kg} \mathrm{CO} / \mathrm{h}$ \\
\hline Mass $\mathrm{CO}_{2}$ required & 2947. \\
\hline
\end{tabular}




\section{APPENDIX B: Derivation of water gas shift reactor model}

Refer to Fogler (2006: 513) for an example of the method to calculate the adiabatic equilibrium temperature for a nonisothermal reactor:

B.1 Plot the equilibrium conversion as function of temperature from the mass balance

- Assume only $\mathrm{CO}, \mathrm{H}_{2} \mathrm{O}, \mathrm{H}_{2}, \mathrm{CO}_{2}$ and $\mathrm{N}_{2}$ is in feed stream.

- Water gas shift reaction stoichiometry:

$$
\begin{gathered}
a C O+b \mathrm{H}_{2} \mathrm{O} \leftrightarrow \mathrm{cCO}_{2}+d \mathrm{H}_{2} \quad \text { with } \mathrm{a}=\mathrm{b}=\mathrm{c}=\mathrm{d}=1 \\
\ln \left(K_{e q}\right)=\frac{5693.5}{T}+1.077 \ln T+5.44 \times 10^{-4} T-1.125 \times 10^{-7} T^{2} \\
-\frac{49170}{T^{2}}-13.148
\end{gathered}
$$

Rate law:

$$
-r_{C O}=k\left(P_{C O} \cdot P_{H_{2} O}-\frac{P_{C O_{2}} \cdot P_{H_{2}}}{K_{e q}}\right)
$$

Equilibrium:

$$
\begin{aligned}
-r_{C O} & =0 \\
0 & =k\left(P_{C O} \cdot P_{\mathrm{H}_{2} \mathrm{O}}-\frac{P_{\mathrm{CO}_{2}} \cdot P_{\mathrm{H}_{2}}}{K_{e q}}\right) \\
P_{C O_{e}} \cdot P_{\mathrm{H}_{2} \mathrm{O}_{e}} & =\frac{P_{\mathrm{CO}_{2 e}} \cdot P_{\mathrm{H}_{2}}}{K_{e q}} \\
K_{e q} & =\frac{P_{\mathrm{CO}_{2}} \cdot P_{\mathrm{H}_{2}}}{P_{\mathrm{CO}_{e}} \cdot P_{\mathrm{H}_{2} \mathrm{O}_{e}}}
\end{aligned}
$$

Stoichiometry:

$$
\text { but } \begin{aligned}
y_{i} & =\frac{P_{i}}{P_{T}} \\
& =\frac{n R T}{V P_{T}} \\
& =\frac{C_{i} R T}{P_{T}}
\end{aligned}
$$




$$
\therefore K_{e q}=\frac{C_{\mathrm{CO}_{2 e}} \cdot C_{\mathrm{H}_{2 e}}}{C_{\mathrm{CO}_{e}} \cdot C_{\mathrm{H}_{2} \mathrm{O}_{e}}}
$$

For the continuous flow system where the following reaction takes place

Let $\quad \mathrm{A}=\mathrm{CO}$

$$
\mathrm{CO}+\mathrm{H}_{2} \mathrm{O} \leftrightarrow \mathrm{CO}_{2}+\mathrm{H}_{2}
$$

$$
\begin{aligned}
& \mathrm{B}=\mathrm{H}_{2} \mathrm{O} \\
& \mathrm{C}=\mathrm{CO}_{2} \\
& \mathrm{D}=\mathrm{H}_{2}
\end{aligned}
$$

then the WGS reaction can be written as $A+B \rightarrow C+D$

The resulting stoichiometric table for the reaction is shown in Table B-1.

Table B-1: Stoichiometric table for flow system (adapted from Fogler, 2006)

\begin{tabular}{|l|l|l|l|l|}
\hline $\begin{array}{l}\text { Species } \\
\text { formula }\end{array}$ & $\begin{array}{l}\text { Species } \\
\text { symbol }\end{array}$ & $\begin{array}{c}\text { Feed rate to } \\
\text { reactor } \\
\text { (mol/time) }\end{array}$ & $\begin{array}{c}\text { Change within } \\
\text { reactor } \\
\text { (mol/time) }\end{array}$ & $\begin{array}{c}\text { Effluent rate } \\
\text { from reactor } \\
\text { (mol/time) }\end{array}$ \\
\hline $\mathrm{CO}$ & $\mathrm{A}$ & $\mathrm{F}_{\mathrm{A} 0}$ & $-\mathrm{F}_{\mathrm{A} 0} \mathrm{X}$ & $\mathrm{F}_{\mathrm{A}}=\mathrm{F}_{\mathrm{A} 0}(1-\mathrm{X})$ \\
\hline $\mathrm{H}_{2} \mathrm{O}$ & $\mathrm{B}$ & $\mathrm{F}_{\mathrm{B} 0}=\Theta_{\mathrm{B}} \mathrm{F}_{\mathrm{A} 0}$ & $-\mathrm{F}_{\mathrm{A} 0} \mathrm{X}$ & $\mathrm{F}_{\mathrm{B}}=\mathrm{F}_{\mathrm{A} 0}\left(\Theta_{\mathrm{B}}-\mathrm{X}\right)$ \\
\hline $\mathrm{CO}_{2}$ & $\mathrm{C}$ & $\mathrm{F}_{\mathrm{C} 0}=\Theta_{\mathrm{C}} \mathrm{F}_{\mathrm{A} 0}$ & $+\mathrm{F}_{\mathrm{A} 0} \mathrm{X}$ & $\mathrm{F}_{\mathrm{C}}=\mathrm{F}_{\mathrm{A} 0}\left(\Theta_{\mathrm{C}}+\mathrm{X}\right)$ \\
\hline $\mathrm{H}_{2}$ & $\mathrm{D}$ & $\mathrm{F}_{\mathrm{D} 0}=\Theta_{\mathrm{D}} \mathrm{F}_{\mathrm{A} 0}$ & $+\mathrm{F}_{\mathrm{A} 0} \mathrm{X}$ & $\mathrm{F}_{\mathrm{D}}=\mathrm{F}_{\mathrm{A} 0}\left(\Theta_{\mathrm{D}}+\mathrm{X}\right)$ \\
\hline $\mathrm{N}_{2}$ & $\mathrm{I}$ & $\mathrm{F}_{10}=\Theta_{\mathrm{I}} \mathrm{F}_{\mathrm{A} 0}$ & - & $\mathrm{F}_{1}=\Theta_{1} \mathrm{~F}_{\mathrm{A} 0}$ \\
\hline
\end{tabular}
with
$\Theta_{B}=\frac{C_{B 0}}{C_{A 0}}$
$\Theta_{C}=\frac{C_{C 0}}{C_{A 0}}$
$\Theta_{D}=\frac{C_{D 0}}{C_{A 0}}$
$\Theta_{I}=\frac{C_{I 0}}{C_{A 0}}$.

For case when feed rates of products $\neq 0$ :

$$
\begin{aligned}
K_{e q} & =\frac{C_{C_{2} e} \cdot C_{H_{2 e}}}{C_{C O_{e}} \cdot C_{H_{2} O_{e}}} \\
& =\frac{C_{A 0}\left(\Theta_{\mathrm{C}}+\mathrm{X}_{\mathrm{e}}\right) \cdot C_{A 0}\left(\Theta_{\mathrm{D}}+\mathrm{X}_{\mathrm{e}}\right)}{C_{A 0}\left(1-\mathrm{X}_{\mathrm{e}}\right) \cdot C_{A 0}\left(\Theta_{\mathrm{B}}-\mathrm{X}_{\mathrm{e}}\right)} \\
\therefore K_{e q} & =\frac{\left(\Theta_{\mathrm{C}}+\mathrm{X}_{\mathrm{e}}\right)\left(\Theta_{\mathrm{D}}+\mathrm{X}_{\mathrm{e}}\right)}{\left(1-\mathrm{X}_{\mathrm{e}}\right)\left(\Theta_{\mathrm{B}}-\mathrm{X}_{\mathrm{e}}\right)}
\end{aligned}
$$

Let $\mathrm{X}_{\mathrm{e}}=\mathrm{X}$ and $\mathrm{K}_{\mathrm{eq}}=\mathrm{K}$ :

$$
\begin{array}{r}
\therefore K=\frac{\Theta_{\mathrm{C}} \Theta_{\mathrm{D}}+\Theta_{\mathrm{C}} X+\Theta_{\mathrm{D}} X+X^{2}}{\Theta_{\mathrm{B}}-X-\Theta_{\mathrm{B}} X+X^{2}} \\
K \Theta_{\mathrm{B}}-K X-K \Theta_{\mathrm{B}} X+K X^{2}=\Theta_{\mathrm{C}} \Theta_{\mathrm{D}}+\Theta_{\mathrm{C}} X+\Theta_{\mathrm{D}} X+X^{2}
\end{array}
$$

Rearranging:

$$
\begin{aligned}
& 0=X^{2}-K X^{2}+\Theta_{\mathrm{C}} X+\Theta_{\mathrm{D}} X+K X+K \Theta_{\mathrm{B}} X+\Theta_{\mathrm{C}} \Theta_{\mathrm{D}}-K \Theta_{\mathrm{B}} \\
& 0=(1-K) X^{2}+\left(\Theta_{\mathrm{C}}+\Theta_{\mathrm{D}}+K+K \Theta_{\mathrm{B}}\right) X+\Theta_{\mathrm{C}} \Theta_{\mathrm{D}}-K \Theta_{\mathrm{B}}
\end{aligned}
$$




$$
X=\frac{-b \pm \sqrt{b^{2}-4 a c}}{2 a}
$$

with $a=1-K$

$$
\begin{aligned}
& b=\Theta_{\mathrm{C}}+\Theta_{\mathrm{D}}+K+K \Theta_{\mathrm{B}} \\
& c=\Theta_{\mathrm{C}} \Theta_{\mathrm{D}}-K \Theta_{\mathrm{B}}
\end{aligned}
$$

\section{Validation of model:}

Compare to Example C-1, Fogler (2006:1024):

- For $\mathrm{K}_{\mathrm{eq}}=1.44$

- Equal molar feed rate of $\mathrm{CO}$ and $\mathrm{H}_{2} \mathrm{O}$, thus $\Theta_{B}=\frac{C_{B 0}}{C_{A 0}}=1$

- No products in feed, thus $\Theta_{C}=\Theta_{D}=0$

$$
\begin{aligned}
X & =\frac{-\mathrm{K}\left(1+\Theta_{\mathrm{B}}\right) \pm \sqrt{\left[K\left(1+\Theta_{B}\right)\right]^{2}-4(1-K)\left(-K \Theta_{\mathrm{B}}\right)}}{2(1-K)} \\
& =\frac{-2.88 \pm \sqrt{5.76}}{-0.88} \\
X & =0.545 \quad \text { or } \quad X=-0.153 \\
\therefore X_{e} & =0.55
\end{aligned}
$$

\section{B.2 Plot the equilibrium conversion as function of temperature from the} energy balance

Assumptions:

- Specific heat $\left(\mathrm{C}_{\mathrm{P}}\right)$ of species and reaction heat $\left(\Delta \mathrm{H}_{\mathrm{RX}}\right)$ is independent of pressure at which reaction takes place.

- $\mathrm{C}_{\mathrm{P}}$ of species stay constant at the average of the reactor feed temperature and calculated equilibrium (or reactor outlet) temperature.

- Adiabatic reactor, thus $\dot{Q}=0$

- No work in reactor, thus $\dot{W}=0$

- All reactants enter the reactor at the same temperature, therefore $T_{i 0}=T_{0}$

- No phase changes occurs in reactor

The energy balance for a reactor operating adiabatically, is derived by Fogler (2006: 486):

$$
\begin{aligned}
X_{E B} & =\frac{\sum \Theta_{i} c_{p_{i}}\left(T-T_{i 0}\right)}{-\Delta H_{R x}(T)} \\
X_{E B} & =\frac{\sum \Theta_{i} c_{p_{i}}\left(T-T_{i 0}\right)}{-\left[\Delta H^{\circ}{ }_{R x}\left(T_{R e f}\right)+\Delta c_{p}\left(T-T_{R e f}\right)\right]}
\end{aligned}
$$


since $T_{i 0}=T_{0}$ :

$\sum \Theta_{i} c_{p_{i}}\left(T-T_{0}\right)=\left(T-T_{0}\right)\left(\Theta_{\mathrm{A}} c_{p_{A}}+\Theta_{\mathrm{B}} c_{p_{B}}+\Theta_{\mathrm{C}} c_{p_{C}}+\Theta_{\mathrm{D}} c_{p_{D}}+\Theta_{\mathrm{I}} c_{p_{I}}\right)$

Numerator:

$$
\begin{aligned}
\Delta c_{p} & =c_{p_{D}}+c_{p_{C}}-c_{p_{B}}-c_{p_{A}} \\
\Delta c_{p} & =c_{p_{H_{2}}}+c_{p_{C_{2}}}-c_{p_{H_{2} O}}-c_{p_{C O}}
\end{aligned}
$$

The specific heat of species involved in WGS reaction was calculated using the following correlation from Çengel and Boles (2011: 907):

$c_{p}=a+b T+c T^{2}+d T^{3}$

The calculated specific heat of all the chemical species involved in the WGS reaction is shown in Table B-2.

Table B-2: Sample calculation of specific heats of species involved in WGS reaction at $370^{\circ} \mathrm{C}$

\begin{tabular}{|c|c|c|c|c|c|c|}
\hline Formula & $\mathbf{a}$ & $\mathbf{b}$ & $\mathbf{c}$ & $\mathbf{d}$ & $\mathbf{T}(\mathbf{K})$ & $\mathbf{c}_{\mathbf{p}}$ (kJ/kmol.K) \\
\hline $\mathrm{CO}$ & 28.16 & $1.68 \mathrm{E}-03$ & $5.37 \mathrm{E}-06$ & $-2.22 \mathrm{E}-09$ & 643 & 30.87 \\
\hline $\mathrm{H}_{2} \mathrm{O}$ & 32.24 & $1.92 \mathrm{E}-03$ & $1.06 \mathrm{E}-05$ & $-3.60 \mathrm{E}-09$ & 643 & 36.88 \\
\hline $\mathrm{CO}_{2}$ & 22.26 & $5.98 \mathrm{E}-02$ & $-3.50 \mathrm{E}-05$ & $7.47 \mathrm{E}-09$ & 643 & 48.23 \\
\hline $\mathrm{H}_{2}$ & 29.11 & $-1.92 \mathrm{E}-03$ & $4.00 \mathrm{E}-06$ & $-8.70 \mathrm{E}-10$ & 643 & 29.30 \\
\hline $\mathrm{N}_{2}$ & 28.9 & $-1.57 \mathrm{E}-03$ & $8.08 \mathrm{E}-06$ & $-2.87 \mathrm{E}-09$ & 643 & 30.47 \\
\hline
\end{tabular}

Note that the model calculated the specific heat at the average of the feed inlet temperature and the calculated equilibrium (or reactor outlet) temperature.

$$
\begin{gathered}
\Delta c_{p}=29.30+48.23-36.88-30.87 \\
\Delta c_{p}=9.78 \frac{\mathrm{kJ}}{\mathrm{kmol.K}} \text { at } 370^{\circ} \mathrm{C} \\
\Delta H_{R x}(T)=\Delta H_{R x}^{\circ}\left(T_{\text {Ref }}\right)+\Delta c_{p}\left(T-T_{\text {Ref }}\right)
\end{gathered}
$$

but $\Delta H^{\circ}{ }_{298 K}=-41100 \mathrm{~kJ} / \mathrm{kmol}$ :

$$
\begin{aligned}
\therefore \Delta H_{R x}(T) & =-41100+9.78(623.15-298.15) \\
\Delta H_{R x}(T) & =-37725.33 \frac{k J}{k m o l ~ C O}
\end{aligned}
$$




\section{B.3 Fundamental WGS reactor model results}

Refer to Figure 21, Table 7 and Table 8 for the input values and results of the sample calculation. Two sensitivity studies of the fundamental WGS reactor model (for the same input values) is displayed in Figure B-1 and Figure B-2.

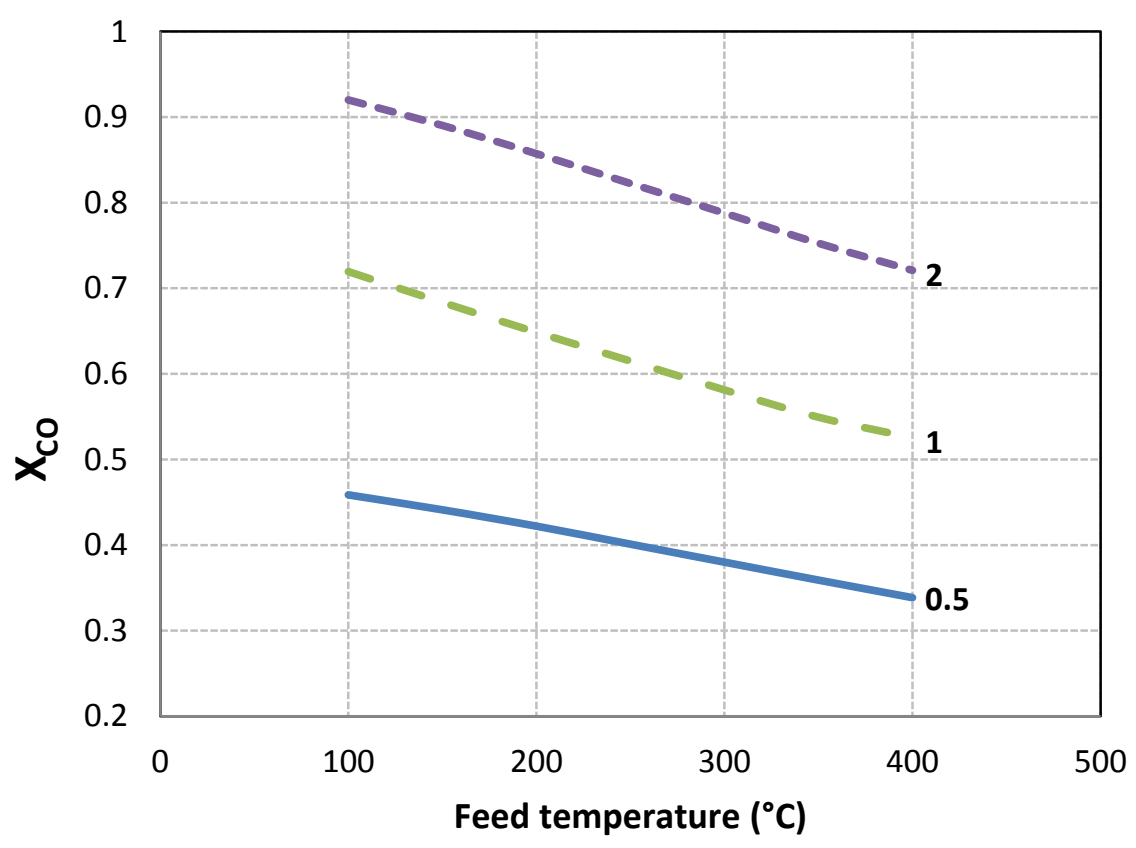

Figure B-1: Comparison of WGS reactor fundamental model results for different $\mathrm{H}_{2} \mathrm{O} / \mathrm{CO}$ feed ratios

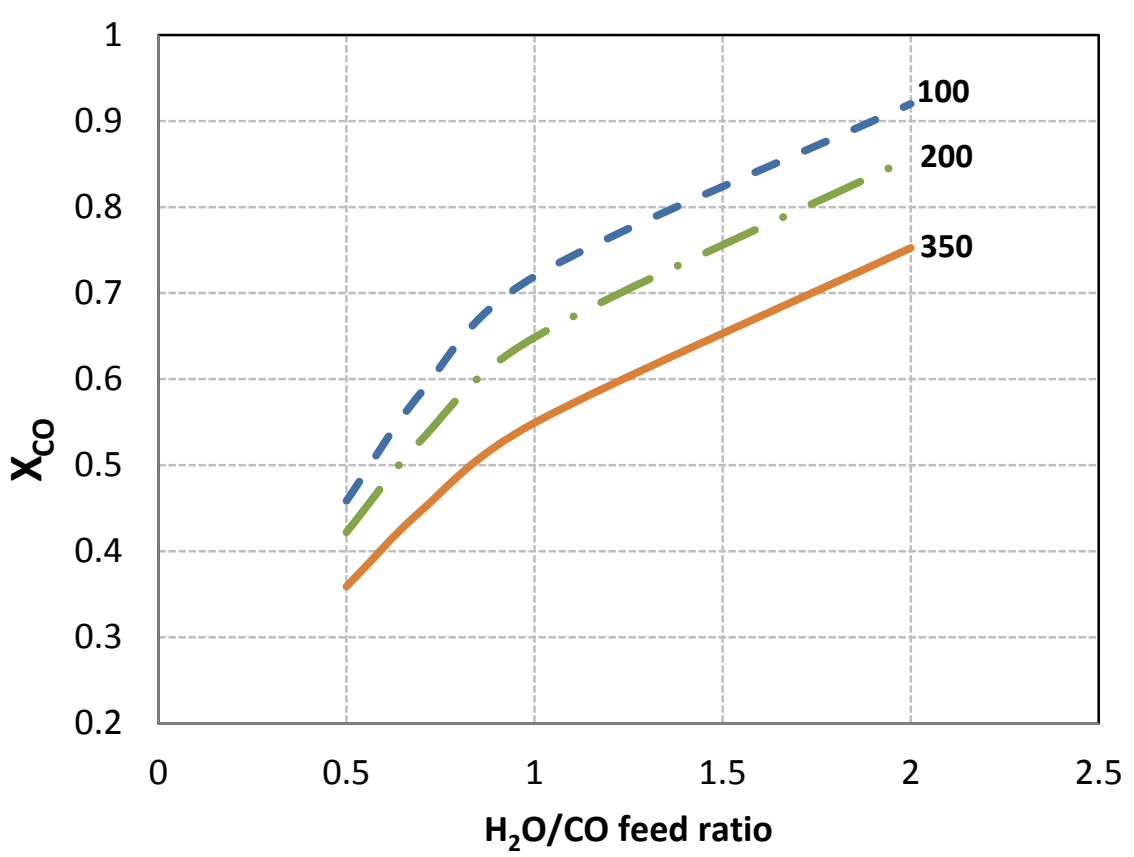

Figure B-2: Comparison of WGS reactor fundamental model results for different feed temperatures 


\section{APPENDIX C: Exergy analysis of the Rankine cycle model}

The ideal Carnot cycle is a totally reversible cycle. However, a Rankine cycle involves irreversibilities, such as heat transfer through a finite temperature difference. As explained previously, the exergy transfer by heat $(Q)$ at temperature $T$, in an environment at temperature $T_{0}$, is as follows (Çengel and Boles, 2011: 437)

$$
X_{\text {heat }}=\left(1-\frac{T_{0}}{T}\right) Q
$$

Exergy is work potential and therefore the work is equal to exergy transfer:

$$
X_{\text {work }}=W
$$

A second law or exergy analysis of the Rankine cycle was performed to determine the exergy efficiency of the Rankine cycle, as well as to reveal where the largest irreversibilities occur. The Aspen Plus $®$ (2009) model of the Rankine cycle is shown in Figure 35 and Figure $\mathrm{C}-1$. The exergy input through heat transfer in the steam generator or boiler was calculated with equation 26 . The only other exergy input into the system was the pump work, as calculated within Aspen Plus $®$ (2009) for each pump. The exergy recovered is the sum of the work output of the three turbines (refer to Table 12).

\begin{tabular}{|c|c|}
\hline $\mathrm{T}_{0}$ & $25^{\circ} \mathrm{C}$ \\
\hline $\mathrm{T}_{\text {boiler out }}$ & $566{ }^{\circ} \mathrm{C}$ \\
\hline \multicolumn{2}{|c|}{ Exergy input: } \\
\hline$X_{\text {heat }}$ & $356739587.78 \quad W$ \\
\hline$X_{\text {pump1 }}$ & $31040 \mathrm{~W}$ \\
\hline$X_{\text {pump2 }}$ & $291142 \quad W$ \\
\hline$X_{\text {pump3 }}$ & $3245713 \mathrm{~W}$ \\
\hline$X_{\text {total in }}$ & $360307482.55 \quad W$ \\
\hline
\end{tabular}

Input temperatures:

Exergy output:

\begin{tabular}{|l|r|}
\hline$X$ recovered & $236834340 \quad$ W \\
\hline 2nd law efficiency & $\mathbf{6 5 . 7} \%$ \\
\hline$X$ destroyed & $123473142.55 \quad$ W \\
\hline
\end{tabular}

An exergy balance was done over each piece of equipment according to Equation 2-10 to reveal the exergy destruction within each component of the Rankine cycle. The exergy mass flows were calculated by the Exercom module (Bilir, 2010), a separately purchased module, which was installed in Aspen Plus $\AA$ (2009). Exercom calculates exergy according to the widely accepted methods and reference states as defined in literature (Szargut et al., 1998). The results of the exergy balance is presented in Table C-1 and the relative exergy destruction in each component is plotted in Figure $\mathrm{C}-2$, which clearly shows that the majority of exergy destruction in the Rankine cycle occurs due to the large amount of heat transferred in the steam generator. 


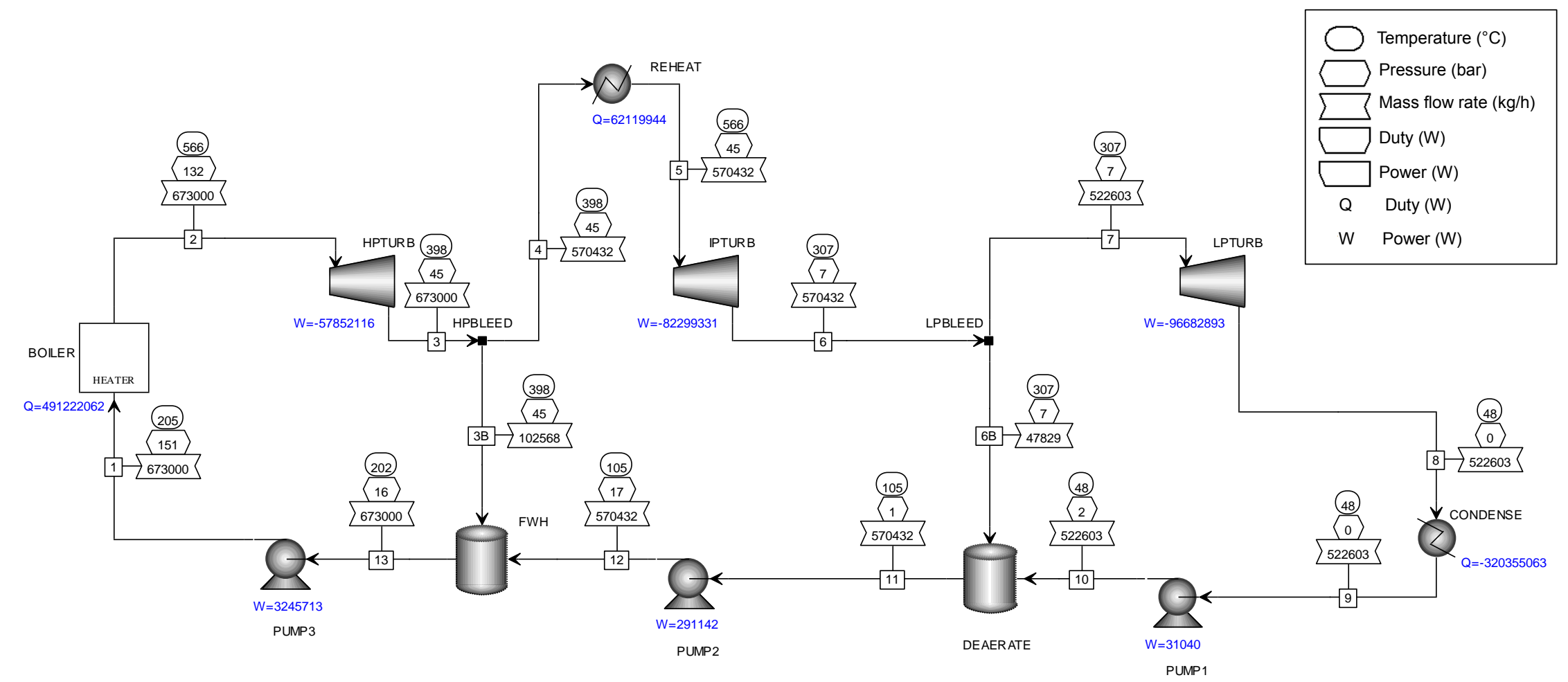

Figure C-1: Aspen Plus $®$ (2009) model of the steam power conversion cycle 
Table C-1: Exergy analysis of Rankine cycle (refer to Figure 35 for the flow diagram of the cycle)

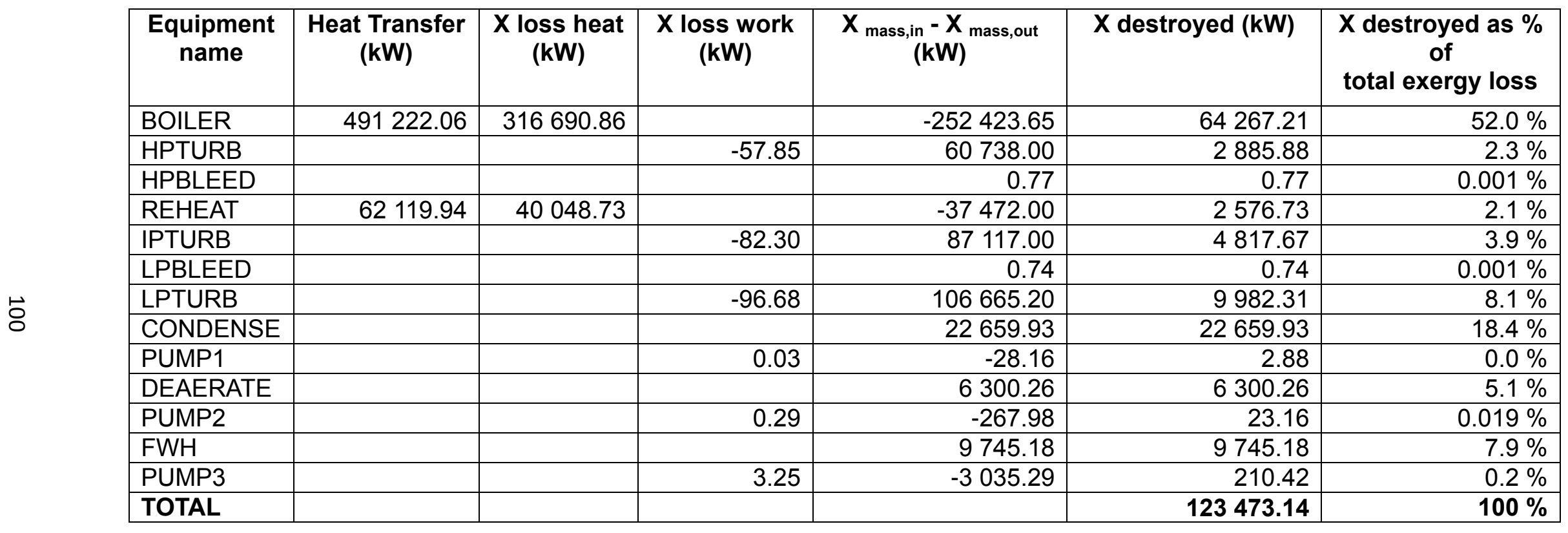




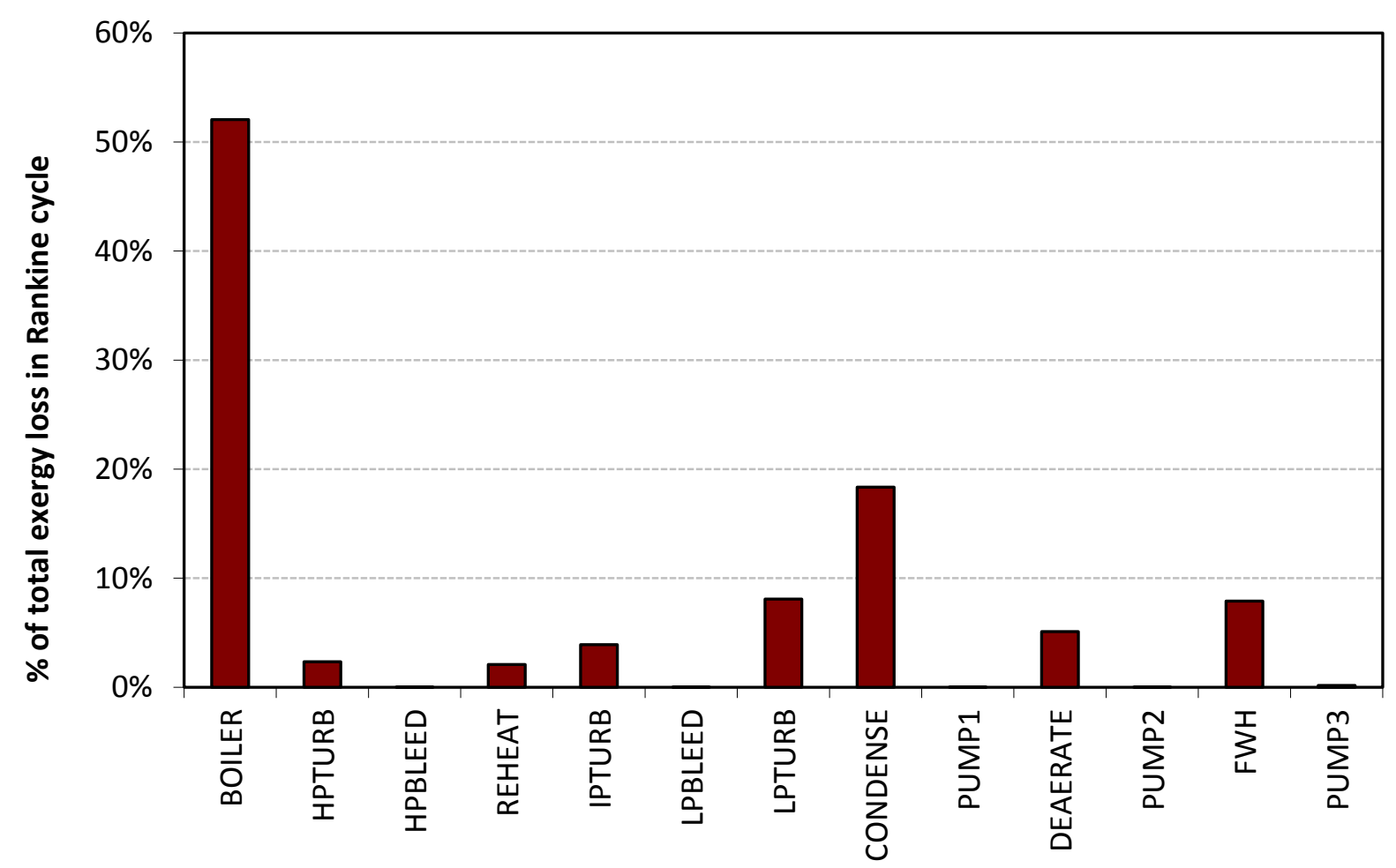

Equipment

Figure C-2: Exergy losses in Rankine cycle Aspen Plus ${ }^{\circledR}$ (2009) model 


\section{APPENDIX D: Aspen Plus ${ }^{\circledR}(2009)$ simulation parameters}

All the process models were simulated in Aspen Plus ${ }^{\circledR}$ (2009). The following simulation parameters were used. All other simulation settings were left on the default setting.

- Ambient pressure: $85 \mathrm{kPa}$

- Property methods and models:

- Process type: Common

- Base method: Soave-Redlich-Kwong (SRK)

- Free-water method: SteamNBS 